\title{
KRISEUDVIKLINGEN I DANMARK
}

\author{
Arne Kurdahl
}

\section{Indledning}

»På denne baggrund rejste formandsskabet afslutningsvist det spørgsmål, om der var enighed om det synspunkt, at der ikke for øjeblikket kan peges på væsentlige igangværende processer i økonomien, der af sig selv kan føre til den styrkelse af betalingsbalanceerhvervene, som er nødvendig for genskabelse af den økonomiske balance. Dette bekræftedes af rådet.

Generelt må - som det også kom til udtryk under drøftelserne - blot en begyndende egentlig løsning af balanceproblemerne forudsætte, at eksisterende mere eller mindre snæversynede særinteresser kommer til at vige for bredere fælles interesser.«

(Dansk Økonomi, maj 77, p. 14)

Selvom det tilsyneladende kun handler om balanceproblemer, så er det reale indhold heri klart nok: $\varnothing$ konomien er stadig i krise, der er ingen tegn på, at den af sig selv kan komme ud af den tilstand, forudsætningen for at den kan begynde her på er, at alle trækker på samme hammel og giver afkald på særinteresser. Den »legitimatoriske ligevægt «, ${ }_{1}^{1}$ der er baseret på kompromisser mellem modsatrettede samfundsmæssige interesser, skal afløses af den fælles almene interesse, der er at få kapitalakkumulationen på fode igen.

Traditionelt har det på venstrefløjen været opfattelsen, at den dybe økonomiske krise fører en radikalisering af arbejderklassen med sig, som om ikke andet, så dog stiller grundlæggende ændringer i det økonomiske og politiske system på dagsordenen. ${ }^{2}$

Blanke har trukket de antagelige konsekvenser af krisen klart op³:

1. Se Bernhard Blanke: Formen und Formwandel des politischen Systems in der bürgerlichen Gesellschaft, $i$ Handbuch V, p. 154.

2. Eks. hos Ole Marquardt: Konjunkturforløb og klassebevidsthed, p. 40, $i$ Den jyske Historiker nr. 1, 1974. Især Mattick har gjort sig til talsmand for denne tese.

3. Se Blanke op. cit. p. $155 \mathrm{ff}$. 
Kriser, der bringer den samfundsmæssige kapitalreproduktion til ophør, og som fordrer forandringer i det historisk opnåede forhold mellem lønarbejde og kapital, fordi merværdiproduktionens betingelser kolliderer med arbejderklassens levevilkår, sådanne kriser fører til systemkriser i betydningen, at også det politiske system må undergå radikale forandringer. Når krisen stiller alternativerne: enten tilbagetrængning af arbejderklassen for at genfremskaffe betingelserne for merværdiproduktionen, og dermed den fornyede kapitalakkumulation, eller en vedvarende stagnation i akkumulationen med effekt $\mathrm{i}$ et kumulativt forfald, bliver betingelserne for det politiske system: enten bliver arbejderklassens indflydelse på og integration i det politiske system trængt ud og arbejderklassen berøvet sine politiske rettigheder og sine organisationer, eller klassekonflikten udtrykker sig i former, der stiller spørgsmålet om forandring af det samfundsmæssige system og forsøg på »revolutionære løsninger« herpå.

Er det som adskiller den nuværende krise fra tidligere recessioner i efterkrigstiden ikke alene dens længde og dybde, men tillige dens karakter som overakkumulationskrise, da bliver krisens løsning, og dermed forøgelsen af beskæftigelsen bundet til en udrensning i den eksisterende kapital og til en sænkning af arbejderklassens konsum. Er den økonomiske politik bundet til krisens $\varnothing$ konomiske løsning, er den derfor tilsvarende bundet til en indskrænkning af industriens arbejdsstyrke og en forværring af dennes levevilkår.

Det der derfor skal undersøges er: hvad er krisens baggrund, hvilke er de resultater, som den lange, næsten ubrudte prosperitetsfase har afsat? Det er disse, der udgør betingelserne for den $\emptyset$ konomiske politiks effektivitet, og dermed eksistensbetingelserne for den politiske tradition i arbejderbevægelsens faglige og politiske organisationer, der bygger på forestillingen om en principielt regulerbar kapitalisme uden systematisk tilbagevendende kriser. Den succes, som denne politiske tradition har haft i efterkrigstiden, har bl.a. været betinget af, at fagbevægelsen har kunnet sikre en voksende realløn, og at staten har stået som garant for den fulde beskæftigelse og reproduktionen udenfor lønarbejderforholdet.

Når fagforeningrne ikke længere kan opretholde endsige forøge reallønnen, når det statslige bidrag til kriserenselsen kommer til at indebære for$\emptyset$ gelse af arbejdsløsheden, bl.a. via forværringen af reproduktionsvilkårene, da bliver spørgsmålet om, hvilke chancer den reformistiske politik har for at bevare sin legitimitet, relevant, og det berettiger tillige, at Blankes postulat om den $\varnothing$ konomiske krises forvandling til en politisk krise tages alvorligt. 
Ingen af de alternativer Blanke peger på, har foreløbigt været aktuelle i Danmark under den nuværende krise, tværtimod peger meget på, at reformismen er blevet styrket. Denne styrkelse kan være kortvarig, hvad sker der når det viser sig, at det vigtigste instrument, indkomstpolitikken ikke virker mht. at genskabe den fulde beskæftigelse, når profitterne stiger og stiger, uden at der skabes beskæftigelse? Dette betyder dog ikke nødvendigvis krise for reformismen, tværtimod kan den, personificeret ved Socialdemokratiet, bruge de manglende resultater som løftestang for indførelsen af nye reguleringsformer, samfundsmæssig styring af kapitalmarkedet, statslige investeringsfonds, $\varnothing D$ etc. som for en tid kan udskyde de politiske legitimitetsproblemer.

For det teoretiske arbejde på den universitære venstrefløj er konsekvenserne af reformismens styrkelse åbenlyse. Hvis der hidtil har været tendenser til at lade det teoretiske arbejde knytte an til radikaliserede dele af arbejderklassen, så indebærer den hidtidige politiske udvikling, at hovedvægten langt snarere skal lægges på at undersøge, hvad baggrunden for denne styrkelse af reformismen har været, og hvilke funktionsbetingelser den vil have fremover. Begge dele fordrer en afklaring af den nuværende krises karakter og dybde, samt hvorledes den fremstår for produktionsagenterne. Især de to første punkter skal tages op her. Jeg skal i artiklen lægge vægten på analysen af krisens karakter i DK, om der er tale om en akkumulationsbestemt krise, forstået som betinget af overakkumulationen, eller om der snarere er tale om et udefrakommende tilbageslag.

Hertil er det nødvendigt:

1. At unders $\emptyset \mathrm{ge}$, om den langfristede udvikling, som har gennemsat sig i industrikapitalen, har medført sådanne ændringer i kapitalforholdet, at forholdet mellem merværdi og profit tilsiger, at akkumulationen ikke kan fortsætte på samme grundlag, (Kap. 3).

2. At undersøge, hvilke ændrede betingelser, den langsigtede udviklings gennemslag i produktionens samfundsmæssige fordeling sætter mht. reproduktionens omfang, kontinuitet og sammensætning. Dette for at stille betingelserne dels for krisepolitikken, og dels for genopsvingenes forudsætninger. Endelig er også arbejdsløshedens sammensætning bestemt af denne udvikling, det samme er dermed arbejdsløshedens afvikling, (Kap. 3).

3. At undersøge, om den seneste krisecyklus mere er en accentuering af dette forhold, end der er tale om en konjunkturkrise, som det fremstår i borgerlig konjunkturteori. (Også fokuseringen på akkumulations- 
formerne, som blot afløsende hinanden, udelukker muligheden af at fremstille krisen som en effekt af en mere eller mindre kontinuert udvikling), (Kap. 4).

Men dette er alene, hvad der vedrører den »indenlandske« del af krisegrundlaget. Men samtidigt er det muligt at krisen er betinget af udefrakommende forhold, og at empirien i så fald »lyver « $\mathrm{i}$ forhold til det teoretiske grundlag. Hvis krisen i virkeligheden er betinget af relative forhold DK udlandet, eller hvis DK er anderledes stillet end udlandet betyder det andre betingelser for kriserenselsen eller genopsvinget her. Derfor må i unders $\varnothing-$ gelsen indgå et fors $\emptyset \mathrm{g}$ på en karakteristik af den danske industris internationale placering. Til den ende er det nødvendigt at reflektere:

1. Karakteren af den danske industris verdensmarkedstilknytning.

2. Karakteren af den danske industri i forhold til »verdensmarkedets industri«.

3. Dansk industris relative placering i forhold til verdensmarkedet, eller de komponenter der indgår i bestemmelsen af konkurrenceevnen.

Dette finder sted i afsnittet om »Krisens karakter« (Kap. 5). Endelig skal jeg i et afsluttende afsnit (Kap. 6) antyde konsekvenserne af indkomstpolitikken som kriseløsningsstrategi.

Men først skal jeg indlede med to tidligere fors $\varnothing \mathrm{g}$ på at angive krisens baggrund. To fors $\varnothing \mathrm{g}$, hvor sammenblandingen af $\emptyset$ konomi og politik fører til en forfejlet opfattelse af krisen, og har politiske konsekvenser, der fratager kriseanalysen det kritiske perspektiv.

\section{Diskussion af kriseanalysen}

Forestillingen om, at den nuværende krise har baggrund i de ændringer i kapitalstrukturen, der har gennemsat sig i 50'erne og 60'erne er naturligvis ikke ny. Fra marxistisk, men også fra socialdemokratisk og liberal (i økonomisk forstand) hold er tesen ført frem, ikke mindst i forsøgene på, fra »ansvarlige « $\varnothing$ konomer at legitimere restriktive indgreb overfor arbejderklassen eller fra andre at begrunde radikale krav til statslig styring.

Jeg skal nedenfor referere to af disse analysefors $\emptyset \mathrm{g}$ kritisk for derigennem at afgrænse og præcisere tilgangen her. 
Herunder skal jeg fors $\emptyset \mathrm{ge}$ at vise, at løsrivelsen af kriseanalysen fra udviklingsdynamikken i kapitalforholdet fører til politisk reformisme. Når de » $\varnothing$ konomiske problemer ... hovedsagelig er af strukturel art «, hvor strukturel har at gøre med markedsmekanismens utilstrækkelighed, med produktionens anarki, bliver de adækvate politiske krav rettet mod »selektive indgreb, der skal sikre den balancerede udvikling, som »markedsmekanismen«« ikke selv har kunnet frembringe. ${ }^{4}$

Kravene retter sig mod en art statskapitalisme, hvor staten regulerer og fordeler produktionen og produktionens resultat, og hvor staten igangsætter selvstændig vareproduktion.

Det bliver politisk reformisme, fordi samfundet fortsat skal hvile på lønarbejde og kapital, det bliver utilstrækkelig reformisme, fordi strategien baserer sig på, at staten kan »gå til venstre « mod en mere dirigeret kapitalisme og derigennem løse kapitalismens problemer. Der ses således bort fra det, som antydes i indledningscitatet fra DØR, at problemet ikke er planmæssig styring eller ikke, men at etablere vakst, at problemet mht. kapitalakkumulationen og dermed beskæftigelsen ikke er at fordele den eksisterende merværdimasse, men at forøge den, og at dermed kriseløsningen og genopsvinget er bundet til forøgelse af kapitalernes profitter $p \stackrel{a}{ }$ bekostning af arbejderklassens lønfond.

Fælles med SØ'erne har DØR opfattelsen af fordelingsforholdet mellem lønarbejde og kapital som bestemmende for profitabiliteten. Stiger lønnen, stiger den på bekostning af profitten (eller stigningen heri) eller omvendt falder profitten skyldes det stigning i lønnen. Men i modsætning til dem, fæstner vismændene kriseproblemet på kort og langt sigt til udviklingen $\mathrm{i}$ profitkvoten. En løsning af krisen bliver dermed bundet til en »omfordeling til fordel for profitterne «.

Med hensigten så vidt muligt, at bringe den kapitalistiske økonomi til at fungere indenfor de eksisterende rammer virker den økonomiske »sagkundskabs « konceptualisering af økonomien optimalt mht. at pege på de faktorer, der på en gang er regulerbare og kapitalistisk rationelle.

For begge gælder således at $\emptyset$ konomi og politik langt fra er adskilte fænomener.

4. Socialistiske Økonomier, Arbejdsløshed, betalingsbalance og økonomisk politik, p. 60. 


\subsection{Madsen og Vangskjær}

I en artikel om krisen i industrien skriver Madsen og Vangskjær, at krisen ikke blot kan opfattes som resultat af en udefrakommende lavkonjunktur ${ }^{5}$, men at den $\varnothing$ konomiske politik spillede en betydelig rolle for den måde krisen slog igennem på. ${ }^{6}$ Hertil kommer ifølge forfatterne, at der allerede fra begyndelsen af 60'erne kan spores tendenser, der viser, at den danske industrikapital var i betydelige vanskeligheder.

Her genfindes således programmatisk en antagelse om krisens karakter, som angiveligt skulle adskille sig fra de officielle (eks. DØRs) forklaringer af krisen, hvor internationale aspekter tillægges en afgørende vægt. Denne alternative opfattelse indebærer hos forfatterne en dikotomisering af analysen mellem 1) de grundliggende årsager til den danske industrikapitals krise og 2) krisegennemslaget, hvor det er hensigten at vise, at både de grundliggende årsager og krisegennemslagets forløb skyldes nationale forhold.

Det kan være relevant at omtale artiklen her af flere grunde, dels fordi den er et af udtrykkene for den neoricardianske opfattelse af krisen (og en række af grundantagelserne i denne artikel, som jeg skal kritisere nedenfor, indgår som forudsætninger i flere af de øvrige artikler i denne samling) som findes blandt Socialistiske Økonomer, men dels også fordi den i hvert fald programmatisk opererer med en opfattelse af, at akkumulationsudviklingen i 60'erne indeholder krisetendenser, som er forudsætninger for forståelsen af krisens gennemslag i 74/75, og ydermere at disse er de væsentligste grunde til krisens gennemslag (forstået som produktionsstagnation og arbejdsløshed) i den danske industri. Altså analysetilgang som udadtil ligner den opfattelse jeg tidligere har fremført om sammenhængen mellem den strukturelle udvikling og konjunkturcyklen. I den udstrækning kritikken af denne artikel kan være præciserende for min egen tilgang skal jeg derfor kort omtale den.

Hos Madsen/Vangskjær er fremstillingen af krisegennemslaget koncentreret om den kronologi, som produktionsstagnationen træder frem $\mathrm{i}$ indenfor forskellige brancher i den danske industri, differentieret efter hvilken »konkurrencesituation « pågældende brancher befinder sig i. Der er to muligheder, enten er en branche beskyttet, eller også er den delvist beskyttet

5. Per Kongshøj Madsen og Kaj Vangskjær: Krisen i industrien, $i$ Krise i Danmark, p. 81.

6. op. cit. p. 82 . 
eller konkurrenceudsat (dette er hos $\mathrm{M} / \mathrm{V}$ i praksis ensbetydende med en differentiering mellem hjemmemarkedserhverv og importkonkurrerendeeller eksporterhverv (betalingsbalanceerhvervene). ${ }^{7}$

I sammenhæng med analysen her er der to ting, der er værd at kommentere nærmere, som indebærer, at M/V's arbejde mindre end et alternativ er blevet et supplement til div. »kriseanalyser « fra den nationaløkonomiske sagkundskab:

1. Konkurrencebegrebet, som er et fiktivt begreb om ekstranational konkurrence indenfor afgrænsede brancher.

2. Kriseopfattelsen og sammenhængende hermed, forholdet mellem de »grundliggende« forhold hos $\mathrm{M} / \mathrm{V}$ og krisegennemslaget.

\section{Ad. 1. Konkurrencebegrebet}

Den danske industri består som sagt hos $\mathrm{M} / \mathrm{V}$ af to typer kapitaler, hvis profitvilkår er vidt forskellige, nemlig af eksport/importkonkurrerende - og hjemmemarkedskapitaler. »Bag denne opdeling i konkurrenceudsatte og beskyttede sektor ligger en antagelse om, at priserne i de konkurrenceudsatte sektorer overvejende bestemmes af prisudviklingen på verdensmarkedet og således er mindre afhængige af omkostningsudviklingen (herunder lønudviklingen) for de pågældende sektorer af dansk industri. Omvendt er prisudviklingen i de beskyttede sektorer uafhængig af den udenlandske prisudvikling og overvejende bestemt af udviklingen i omkostningerne. I disse sektorer antages priserne med andre ord bestemt ved at kapitalisterne til de variable omkostninger pr. enhed adderer en bruttoavance til dækning af kapitalisternes krav til bruttoprofitten. ${ }^{8}$ Konkurrencen er således nationalt ekstern. Konkurrencen mellem kapitaler finder kun sted som konkurrence mellem forskellige nationalkapitaler. Ifølge dette må hjemmemarkedssektoren nærmest være krisefri, i hvert fald i profitmæssig henseende. Stiger omkostningerne, som følge af stigende kapitalindsats eller som følge af stigende lønninger, eller synes kapitalisterne at profitten er for lav, kan de blot forhøje bruttoavan-

7. Fordi konkurrence her er ensbetydende med konkurrence mellem forskellig nationale kapitaler.

8. op. cit. p. $88-91$. 
cen. ${ }^{9}$ Hvad angår hjemmemarkedskapitalen kan kriser kun skyldes efterspørgselsproblemer, evt. introduceret via konkurrencekapitalerne eller på grund af politiske indgreb, altså egentlig kun af økonomieksterne (i forhold til den afgrænsede hjemmemarkedskapital) faktorer.

Langt hen er M/V's forståelse af de økonomiske funktionssammenhænge således på linie med neoklassisk økonomi (og monetaristerne): den private sektor udløser ikke de cykliske svingninger, men er nærmere »chokabsorberende«, hvor »chokkene« er eksogene, eks. statslige indgreb via finans- eller pengepolitik, lønforhandlinger, udenrigshandel. ${ }^{10}$

Konkurrencen kan her maksimalt forstås som konkurrence mellem nationalkapitaler, som forholdet mellem danske eksport- og importkonkurrerende kapitaler og udenlandske do.

Men selv på dette plan mangler en opfattelse af, hvad indholdet i konkurrencen er, og denne mangel er samtidig baggrunden for, at $\mathrm{M} / \mathrm{V}$ kan »overse«, at konkurrencen også er et determinerende forhold i udviklingen af hjemmemarkedskapitalen.

Priserne i de konkurrenceudsatte sektorer er bestemt af priserne på verdensmarkedet, »og altså« mindre afhængige af omkostningsudviklingen i dansk industri ${ }^{11}{ }^{11}$

Markedsprisen er noget givet, og for enkeltkapitalisterne i DK bestemmes konkurrenceevnen af forholdet mellem omkostningsudvikling og denne fixe markedspris. Profit er således i virkeligheden et cirkulationsfænomen uden bestemmelse i den producerede værdi, profittens størrelse er bestemt af forholdet mellem en ubestemt markedspris og produktionsomkostningerne. Omvendt for hjemmemarkedskapitalen, her er profitten noget givet og markedsprisen den afhængige.

I virkeligheden formår $\mathrm{M} / \mathrm{V}$ således at placere sig med begge ben solidt plantet i konkurrencens illusioner, uden at kunne gennembryde dem.

9. Det er også inflationsforklaringen hos nogle af SØ'erne, sml. artikel af Carsten Koch og Helge Brink i samme p. 41: »en del af inflationen kan derfor ses som et resultat af, at kapitalisterne fors $\varnothing$ ger at genoprette den selvfinansieringsgrad, de anser for nødvendig.«

10. Sml. M. Bolle: Globalsteuerung und Ökonomische Krise, i Handbuch V.

11. Men hvad bestemmer markedsprisudviklingen, når denne er mindre afhængig af dansk industri, og hvorfor er den mindre afhængig af dansk industri? Begrundelsen må være, at den mindre afhængighed skyldes at dansk industri ikke er markedsprisbarende, og det er den ikke i kraft af sin størrelse, fordi den udgør kun en mindre del af markedet. Det er svært at se, hvordan det stemmer overens med karakteristikken af eksportindustrien som niche-præget, som hører til SØ’'ernes kæpheste. sml. p. 235-36 i samme. 
I den marx'ske analyse er konkurrencen som formidlingsled for dannelsen af markedsværdien og gennemsnitsprofitraten imidlertid dobbelt bestemt:

Konkurrencen i den første bestemmelse er konkurrencen på samme vare, som udligner individuelle værdier til en markedsværdi, hvis pengeudtryk er markedsprisen. I denne forstand optræder markedsprisen for enkeltkapitalerne som noget givet, i forhold til hvilken hans individuelle profit er bestemt som forskellen mellem hans produktionsbetingelser (kostpriser) og den givne markedspris. Konkurrencen formidler her den mængde samfundsmæssigt gennemsnitligt arbejde, der er nødvendigt for produktion af den samlede masse af varer indenfor den sfære. Den formidler således også bestemmelsen af, om den mængde arbejde, der er nedlagt i produktionen er samfundsmæssigt nødvendigt, dvs. om det er værdidannende. Denne bestemmelse fremkommer først efter at arbejdet er nedlagt, i realisationen af varens værdi. Om det anvendte arbejde indenfor en produktionssfære er værdidannende eller omvendt, det nye samfundsmæssige gennemsnit, den nødvendige arbejdsmængde viser sig for enkeltkapitalerne, som manglende profitrealisering (eller som manglende realisering af omkostningerne for de svageste enkeltkapitaler), og for alle som en tvang til at nedsætte det forbrugte arbejde. I produktionsfaktorteorien og hos $\mathrm{M} / \mathrm{V}$ optræder dette forhold som en tvang til reduktion af faktorpriserne, og det vil i praksis (fordi det er den eneste mulige) sige reduktion af lønudgiften, enten gennem lønsænkning eller gennem produktivitetsforøgelser. Begge har den for enkeltkapitalisterne heldige (uerkendte) effekt, at de forøger merværdien og dermed profitten til fordeling.

Dette aspekt af konkurrencen, som via dannelsen af markedsprisen tvinger kapitalerne til at egalisere produktionsbetingelserne, finder sted indenfor samme branche og derfor også indenfor hjemmemarkedssektoren (som netop er afgrænsede brancher).

Konkurrencens andet aspekt er konkurrencen mellem kapitaler indenfor forskellige brancher, som udligner de forskellige gennemsnitlige profitrater til en samfundsmæssig gennemsnitsrate. Denne tendens som formidles via en konkurrence på kapitalinvesteringer - som jagt på ekstraprofitter overalt i samfundet - er en konkurrence om fordelingen af den samfundsmassige profit. Processen, som især formidles af kreditten, er virkende, ligegyldig om brancherne interfererer eller ligegyldig, om der er tale om en »streng « opdeling af produktionen i hjemmemarkeds- og eksportkapitaler. Indenfor 
alle sfærer af produktionen tvinger den kapitalerne til at reducere kostpriserne for at realisere en ekstraprofit eller blot gennemsnitsprofitten, altså til at forcere produktivitetsudviklingen.

Denne proces's gennemslag viser sig i virkeligheden også hos $\mathrm{M} / \mathrm{V}$ (selvom de ikke ved det) i to henseender:

1. »at det ikke er muligt éntydigt at karakterisere konkurrencesektorer som sektorer med stigende lønkvote og omvendt. Dette kan naturligvis skyldes, at den anvendte opdeling af sektorerne på konkurrencesektorer og beskyttede sektorer er for aggregeret eller upræcis - eller direkte fejlagtig. En anden mulighed er, at andre forhold end konkurrencesituationen dominerer udviklingen i lonkvoten «. ${ }^{12}$

2. »I denne periode er det de teknologisk mest progressive sektorer, som kan bevare eller forøge profitandelen, medens sektorer med lavere produktivitetsudvikling ikke, på trods af at de udviser de højeste prisstigninger, har kunnet kompensere for vaksten i pengelфnningerne. « ${ }^{13}$

Og som det fremgår, ${ }^{14}$ er der ingen sammenhæng mellem grad af konkurrenceudsathed og produktivitetsudvikling.

Tydeligere kan det næsten ikke siges. Den postulerede fordeling af sektorerne (efter 60) har overhovedet intet på sig. Hverken teoretisk eller empirisk er der derfor nogen grund til at operere med denne opdeling. Hvorfor de gør det alligevel, skal jeg vende tilbage til.

Opdelingen baserer sig på en forestilling om, at kapitaler kun kan konkurrere på samme brugsværdi, hvorved markedsprisen fastlægges som noget givet (jvnfr. verdensmarkedsbestemmelsen) og profitten som et residual. Der ses bort fra konkurrencen om fordeling af den samfundsmæssige merværdi, der formidler gennemsnitsprofitraten, alligevel reflekteres den som noget givet, som en »bruttoavance« (som i hjemmemarkedssektoren) uden dens dannelsesproces. Begge er forestillinger, der til forveksling ligner det enkeltkapitalisterne kan se for øjnene af sig, og som de kalkulerer i forhold til, men forestillinger, som ikke burde danne grundlag for en analyse af de samfundsmæssige sammenhænge. Manglen på reflektion over, hvad indholdet i konkurrencen er, er også det, der af-

12. op. cit. p. 91, min understregning. Den profitklemme, som fremføres flere steder i artiklen, for konkurrenceudsatte sektorer, og dermed ensidigheden i udlandskonkurrencen, har altså intet på sig, siger forfatterne her.

13. op. cit. p. 92 , min understregning.

14. af deres fig. 3 p. 90. 
gørende fratager $\mathrm{M} / \mathrm{V}$ en adskillelse fra anden borgerlig vulgærøkonomi. For dem er der kun gradsforskelle, økonomiens sammenhænge er principielt de samme, overvejelser over udviklingsdynamikken og strukturen i den kapitalistiske produktion, som ville indebære reflektioner over gennemsættelsesbetingelserne for profitraten, findes ikke her, og kriser eller strukturkriser kan derfor indenfor hjemmemarkedssektoren kun opfattes som kommende udefra. ${ }^{15}$

Konkurrencen er således et udtryk, som må ses i forhold til gennemsættelsen af gennemsnitsprofitraten, som et resultat af udbredelsen af gennemsnitlige produktionsbetingelser, ikke blot $\mathrm{i}$ forholdene mellem nationale kapitaler, men fuldt så meget som et integralt led i konkurrencen indenfor brancher, og det vil tillige sige indenfor det, der her kaldes hjemmemarkedssektorer.

Dermed er den tillige indfaldsvinkel til at forstå nogle af problemerne i forbindelse med den keynesianske konsumforstrækningspolitik. Krisen er karakteriseret ved forskydninger indenfor konkurrencefelter (brancher) fra kapitaler med lavere mod kapitaler med højere organisk sammensætning, altså mod de kapitaler, der producerer med de bedste produktionsbetingelser, som har den laveste relative kostpris, eller som overhovedet kan opretholde en profitabel produktion. Denne forskydningsproces efterlader krakkede kapitaler, destruktion af kapital i materiel form, af kapitaler der ikke er produktive nok i forhold til det sig bevægende centrum for branchen.

Interventioner, der primært sigter mod at undgå denne braklægning og dermed arbejdsløshedssituation, må tilsikre, at profitniveauet kan opretholdes også for de kapitaler, der producerer under de dårligste betingelser, må altså sikre at markedet ikke indskrumpes. Men mere end det. Selv med et tilstrækkeligt stort marked ophører konkurrencen på ekstraprofitter ikke at være virksom. Kapitaler med overgennemsnitlige produktionsbetingelser opnår ekstraprofitter og dels må disse reinvesteres, hvad der betyder yderligere udbygning af produktionskapaciteten, dels må de for at fastholde ekstraprofitmuligheden søge at konfirmere deres tekniske forspring gennem yderligere produktivkraftsforøgelser. Begge processer skærper således for de lavproduktive kapitaler realiseringsproblemet som et profitproblem, og skærper dermed kravene til den keynesianske reguleringspolitik. Nu skal

15. se nedenfor under ad. 2 . 
den ikke blot fastholde markedet på et givet niveau, men tilsikre et stadigt ekspanderende marked, eller ekspansionen i de ekstraprofit-bærende kapitaler skal være så meget større end produktivitetsstigningen, at de opsuger den arbejdskraft, der er udstødt i de lavproduktive kapitaler. Arbejdsløsheden er derfor ikke, som hos $\mathrm{M} / \mathrm{V}$, kun et problem om, at efterspørgslen falder (pga. stram $\varnothing$ konomisk politik), men at den ikke udvides hurtigt nok i forhold til produktiviteten, fordi akkumulationshastigheden, som skaber efterspørgslen, aftager. ${ }^{16}$

Statsinterventioner af denne art udskyder eller hindrer gennemsættelsen af udligningen af profitraten indenfor brancher, og fastholder dermed på den ene side inflationsproblemet, for så vidt det er båret af de kapitaler, der producerer under de dårligste betingelser, forringer på den anden side konkurrenceevnen, fordi den søger at fastholde markedsandele til kapitaler, hvis produktionsbetingelser ikke tilsiger dem nogen konkurrenceposition overhovedet. Som gennemsnit forringer den tillige nationalkapitalens konkurrencestilling, fordi den netop ikke konsoliderer eller gennemsætter de gennemsnitlige produktionsbetingelser. Dette synes også DØR at have erkendt. I april-77-redegørelsen taler de eksplicit om, at den førte arbejdsløshedsbegrænsende politik fastholder kapitalismen i en længere stagnativ fase, altså hindrer det hurtige sammenbrud i en renselseskrise, men på den anden side ikke formår at bringe akkumulationen på fode igen.

Skiftet i økonomisk konceptualisering i bestemte lande, kunne passende diskuteres i forhold hertil, i stedet for som et mere eller mindre voluntaristisk fænomen. Også den mere end tilbageholdende økonomiske politik i DK kan have baggrund heri.

16. Derfor er forudsætningen for keynesianismens succes, som bla. fremhævet af Mattick (i Marx og Keynes), at der sideløbende med udvidelsen af efterspørgslen fra statens side finder en forøgelse af profitraten sted, som sikrer, at den private sektor selv skaber efterspørgslen på længere sigt. Men problemet, som er antydet i teksten, behandles også i den postkeynesianske diskussion af forudsætningerne for vækst i ligevægt: investeringer har både en indkomsteffekt og en kapacitetseffekt, men kapacitetseffekten er større og længerevarende end indkomsteffekten, (el. beskæftigelseseffekten). Betingelsen for ligevægt i vækst er derfor, at efterspørgslen (dvs. investeringerne) vokser svarende til forøgelsen af kapacitetseffekten etc. Sml. E. Glombowski, m. fl.: Gesamtwirkschaftliche Grundbegriffe und Beziehungen, $i$ Mehrwert 8, p. 194 - 200. Dette reflekteres derimod kun sjældent i DØR's beretninger, der næsten alene diskuterer investeringers efterspørgselseffekt, som betingelse for udnyttelse af den eksisterende kapacitet. 


\section{Ad. 2. Kriseopfattelsen}

Kriseopfattelsen hos $\mathrm{M} / \mathrm{V}$ er, i forlængelse af hvad der blev sagt under punkt 1), i den udstrækning, der overhovedet peges på kriseårsager, egentlig eksogen.

»Samspillet mellem udviklingen i pengeløn, priser og produktivitet (har) medført et pres på profitraten. Det pres nedad, som 1972 og 1973 aftog noget, blev forstarket af krisen i 1974 og 1975. Især brancher, som er konkurrenceudsatte har været udsat for dette pres. $\ll^{17}$

Men hvad har da betinget krisen? At faldet i profitraten (de mener profitkvoten) blev forstærket $i$ krisen, angiver ikke hvorfor krisen kom. Men heldigvis har de en »strukturel« forklaring: fordi der ikke er konkurrence i hjemmemarkedssektoren, og lønstigninger derfor her kan væltes over på priserne, kommer eksportindustrien, med fastlåste markedspriser og tilsvarende lønstigninger, i klemme. (Sml. »især brancher som er konkurrenceudsatte har været udsat for dette pres« ovenfor). Krisen kunne så være betinget af en relativ profitklemme i forhold til verdensmarkedet, men det har ifølge $\mathrm{M} / \mathrm{V}$ ikke været den umiddelbare årsag til krisen, for »krisen brød først ud i udprægede hjemmemarkedsorienterede erhverv samt i tekstilområdet før de konkurrenceudsatte industrier blev ramt, dvs. før den internationale krise ramte den danske eksport. ${ }^{18}$

I virkeligheden har profitklemme og krise altså her ikke andet med hinanden at gøre, end at krisen skærper profitklemmen. Hvis profitklemmen derfor skulle være årsag til krisen, er M/V nået frem til den unikke konklusion, at krisen skaber krisen. Men i realiteten, fordi de forveksler krisens gennembrud med dens årsag, og fordi krisen først slår igennem i den (efter deres opfattelse, se under pkt. 1) »krisefrie« hjemmemarkedssektor, mangler de helt en analyse af krisens årsag, som betinget af den фkonomiske udvikling.

Senere, da krisen var slået igennem, blev den danske eksport »ramt « af den internationale krise, som er en realitet uden hensyntagen til den danske $\phi$ konomiske udvikling.

I begge tilfælde, er der derfor tale om uafhængige (og i denne henseende ikke-økonomiske) forholds kriseskabende udvikling. Krisen kan således alternativt være betinget af:

17. op. cit., p. 120 , min understregning.

18. op. cit., p. 121, min understregning. 
1. Den statslige $\varnothing$ konomiske politik.

2. Det internationale tilbageslag.

Dermed står det også klart, at deres mål med undersøgelsen ikke er den $\emptyset$ konomiske udvikling, ikke de modsætninger heri som skærpes, altså ikke en unders $\varnothing$ gelse af den selvstændiggjorte og selvstændigg ørende udvikling i de forhold, der konstituerer disse modsætninger, og som betinger krisen som en kapitalistisk krise. Men hensigten er at få dokumenteret, at krisen var betinget af uhensigtsmæssige politiske indgreb (i den krisefrie hjemmemarkedssektor). Dermed kan forklaringen på, at de fastholder opspaltningen af sektorerne på trods af dens meningsløshed, kun være:

1. for at kunne konstatere krisen som hjemmemarkedsbetinget.

2. som løftestang for deres lønklemmeopfattelse, som uagtet at den ikke bruges til andet, end at forklare forskydningen mellem hjemmemarkedsorienterede og eksportorienterede brancher, og dermed betalingsbalanceproblemet, »svæver over vandene« som var det krisens virkelige baggrund. ${ }^{19}$

Deres kritikgenstand er således ikke kapitalismen, eller den kapitalbetingede udviklingsproces, men staten, eller rettere den politik staten har ført, ikke af dennes kapitalistiske karakter, ikke af den klassekarakter, men alene af at den var uhensigtsmæssig, at den var utilstrakkelig til at løse krisen, til at undgå arbejdsløsheden. Derfor er deres opfattelse af de kort- og langsigtede problemer i den danske økonomi heller ikke på nogen måde i modstrid med de »officielle udtalelser « og forklaringerne fra Det økonomiske Råd. Tværtimod er de ganske på linie med disse (mest dog med den mere ureflekterede del heraf, se nedenfor om DØR's kriseforklaring), årsagen til »balanceproblemerne « (som der er tale om hos begge parter) er en og den samme: profitklemmen som følge af for store lønstigninger. ${ }^{20}$

Hermed er også allerede gjort klart, at dikotomiseringen ovenfor mellem grundliggende årsager og krisegennemslaget på den ene side forbliver et postulat og på den anden side bliver til en løsrivelse af de to forhold.

19. Tog man dem på ordet skulle krisen være lig underskuddet på betalingsbalancen, hvad de muligvis mener, sml. p. 120 og især p. 121.

20. Sml. cital fra p. 58 i DØR's April-76-rapport, i næste afsnit. Hvis krisen har sin årsag i lønstigninger alene, hvis dette tillige er det langsigtede problem, og dette forstærkes af krisen, hvad er da den mulige krisepolitik andet end lønbegrænsning, på kort sigt generelt og på langt sigt især hjemmemarkedssektoren (eks. i stat, handel, etc.). 
Den forbliver et postulat, fordi de grundliggende forhold og krisegennemslag er et og det samme, nemlig »forholdet mellem løn, produktivitet og priser «, krisen kan kun forstås som en forstærkning af det forhold, der stort set altid har gjort sig gældende. Det bliver til en løsrivelse, fordi dette ikke hos forfatterne $\mathrm{i}$ virkeligheden er kriseårsagen, men krisen skyldes udefrakommende »chok«, primært fra statens side, som ikke begrundes i denne lønklemme. ${ }^{21}$

Der finder således ikke nogen diskussion sted af, hvorledes de langsigtede forhold »skaber baggrund for «, »at krisen først viser sig i hjemmemarkedserhvervene «, ${ }^{22}$ altså ikke nogen diskussion af, hvorledes den langsigtede udvikling i 60'erne sætter betingelserne for krisens gennemslag og heller ikke for de kortsigtede forholds kriseudløsende effekter.

Den afgørende mangel hos M/V i forhold til forståelsen af den nuværende krise er således, at deres opfattelse af det $\varnothing$ konomiske system er statisk. Lang- og kortsigtede problemer er hos dem de samme, er en tilstand som (altid) har været gældende, men ikke problemer om den nødvendige udviklingsretning, ikke problemer, som er forbundet med den specifikke kapitalistiske dynamik, og derfor ikke problemer som kan konciperes indenfor det $\varnothing$ konomiske system i sig selv.

Den kritik af kapitaludviklingen, som kan affødes heraf bliver tilsvarende (radikal) reformistisk, som hviler på et grundlag, der opfatter kapitalismen som krisefri, hvad angår systemets funktionssammenhænge. ${ }^{23}$

21. At »byggekrisen« kan forståes som et nødvendigt fors $\emptyset \mathrm{g}$ på fra statslig side at modvirke fordelingen af de samfundsmæssige produktionsressourcer på hjemme-/ eksportproduktion, som hos vismandsøkonomerne gentagne gange er blevet betegnet som den strukturelle baggrund for betalingsbalanceunderskuddet, reflekteres ikke hos M/V. Dette er beklageligt, for det første fordi forfatterne selv lægger vægt på den strukturelle uligevægt mellem hjemmemarkeds- og eksportproduktion, og for det andet for så vidt eksemplet ville være velvalgt til at belyse problemerne omkring strukturpolitikken. Med udgangspunkt i dette eksempel kan i hvert fald vises to ting.

1. at strukturproblemet her først blev aktuelt (det vil sige nødvendigt at løse), da det fremtrådte som et konjunkturproblem, dvs. først i sammenhæng med det hastigt voksende underskud på betalingsbalancen.

2. at den politik, der rettes mod dette strukturproblem, primært har en konjunkturstabiliserende hensigt og funktion, og kun »virker« under forudsætning af, at konjunkturen i øvrigt er »medløbende «.

22. op. cit. p. 101.

23. Når forfatterne derfor andet steds (i Arbejdsløshed, betalingsbalance og økonomisk politik, udarbejdet af Socialistiske Økonomer) hævder at $\varnothing$ konomiske kriser er en uadskillelig del af kapitalismen (p. 82), forbliver det et postulat, som ikke lader sig begrunde i deres opfattelse af det $\varnothing$ konomiske system. 


\subsection{Det økonomiske Råd}

Også det $\varnothing$ konomiske »orakel « har beskæftiget sig med sammenhængen mellem den langsigtede $\varnothing$ konomiske udvikling og den nuværende krise.

I den halvårlige rapport fra april 76 diskuterer $\mathrm{D} \emptyset \mathrm{R}$, om beskæftigelseskrisen kan siges at være strukturelt betinget, dvs. ikke alene kan henføres til konjunkturtilbageslaget i 74/75, men må tilskrives »mere grundliggende forhold «. Til udgangspunkt afvises, at den store og samtidige internationale arbejdsløshed kan forklares som strukturelt bestemt i den forstand, at forskydningerne mellem sektorerne, ændringer i udbuds- efterspørgselsmønstret skulle være hovedårsagen til beskæftigelsessituationen. Heller ikke de ofte fremførte angreb på den solidariske lønpolitik, hvorefter denne skulle have sat de rådende efterspørgsels/udbudsforhold på arbejdsmarkedet ud af kraft med hensyn til deres bestemmelse af lønrelationerne, kan ifølge DØR forklare den danske variant af beskæftigelsessituationen.

I stedet anfører DØR to sammenhænge, der ifølge dem har karakteriseret og har været bestemmende for den nuværende såvel internationale som danske situation: For det første at beskæftigelsestilbagegangen hænger sammen med den bevidst tilbageholdende $\varnothing$ konomiske politik, der føres i de mht. det internationale konjunkturforl $\varnothing$ b, toneangivende lande. I denne sammenhæng må strukturkrise primært siges at være begrundet $\mathrm{i}$ »de faktorer, som tenderer at skabe inflation og betalingsbalanceproblemer ved fuld beskæftigelse. $\ll^{24}$ Ikke stagflation, eller ikke de faktorer, der fremkalder sameksistensen af inflation og stagnation, men den højkonjunkturelle inflation identificeres sammen med betalingsbalanceproblemerne som det grundliggende problem, dette fordi problemet ikke, som DØR foregiver, vedrører den øjeblikkelige internationale beskæftigelsessituation, der er kendetegnet ved stagflation. Men det vedrører specifikt vanskelighederne for Danmark, ${ }^{25}$ hvor inflationen, der hos DØR primært skyldes lønstigninger, kan eksisterer side om side med en stagnation, der netop er begrundet i betalingsbalancevanskeligheder pga. den forringede konkurrenceevne, der for DØR ligeledes skyldes lønstigningerne. Her er der således ingen modsætning mellem inflation og stagnation (krise),

24. Dansk Økonomi, April 76. Op. cit. p. 52, min understregning.

25. Det fremgår også af afslutningssalutten på dette afsnit: »Konklusionen synes at blive, at det, der har været Danmarks korttidsproblem gennem årtier og stadig er det store problem, nemlig betalingsbalancen og konkurrenceevnen, også er kærnen i det såkaldte strukturelle arbejdsløshedsproblem. « op. cit. p. 58. 
tværtimod er de betinget af samme forhold og skal derfor overvindes med samme middel, indkomstpolitik. Dermed fremgår også med al tydelighed at strukturproblemet i denne sammenhæng er et dansk strukturproblem og kun kan løses som et sådant. Kun ved at eksportere sig ud af krisen, gennem sænkning af lønninger og forøgelse af profitten, altså forbedring af »konkurrenceevnen «, kan det langsigtede problem »profitklemmen « $1 \varnothing s^{2}{ }^{26}$

For det andet »følgerne af, at en given vareproduktion kan tilvejebringes ved anvendelse af et faldende antal arbejdstimer. « som kommer til udtryk i en »stagnerende og i de seneste år en faldende efterspørgsel efter arbejdskraft fra de private byerhverv « ${ }^{27}$ Forudsætningerne for at fald i arbejdskraftsforbruget pr. produceret enhed ikke medfører fald i beskæftigelsen er ifølge DØR, at produktionen (BFI) vokser i samme takt. Det har ikke været tilfældet, tværtimod »siden »industrialiseringsgennembruddet « i slutningen af 1960'erne har produktionens vækstrate udvist en faldende tendens ${ }^{28}$ og dette sammenholdt med den stigende vækst i produktiviteten ligger bag den afdæmpede vækst i byerhvervenes arbejdskraftsefterspørgsel i anden halvdel af 60'erne og faldet i arbejdskraftsforbruget siden 71. Problemet der stiller sig for DØR er med andre ord sammenhængen mellem faldet i mængden af levende arbejde pr. vareenhed og væksten i produktionsresultatet. Altså at væksten i nyværdien er for lille i forhold til produktivitetsstigningen, men dette udtrykker kun problemet, forklarer det ikke. Beskæftigelsen resulterer ikke af stigningen i nyværdien, men af stigningen i akkumulationen. Stigningen i den mængde konstant kapital, der skal konsumeres i produktionen er afgørende for beskæftigelsen. Dermed er det heller ikke naturligt, »at forudsætningen for, at det stadigt kraftigere faldende arbejdskraftsforbrug pr. produceret enhed ikke fører til faldende beskæftigelse, er ..., at produktionen stiger mindst lige så kraftigt som arbejdskraftsforbruget pr. enhed falder. $\ll^{29}$ Forudsætningen er derimod at forbruget af kapital i produktionsprocessen vokser lige så kraftigt som

26. Dansk Økonomi nov. 76 p. 79. Der er således ikke nogen modsætning mellem »dette strukturproblem« og det følgende som $\mathrm{S} \emptyset$ antager (se »Arbejdsløshed, betalingsbalance og $\varnothing \mathrm{ko}-$ nomisk politik, en kritik ...« p. 47), begge er betinget af det samme - lønstigninger og profitklemme - og begge vedrører forholdet generelt for hele den danske industri og ikke for eksportindustrien alene, og begge skal »løses« med indkomstpolitik, dvs. at lønstigningerne skal evt. hjulpet af devalueringer, holdes nede.

27. Dansk Økonomi, April 76, op. cit. p. 52.

28. op. cit. p. 55.

29. op. cit. p. 53 - 55. 
forbruget af arbejdskraft falder pr. produceret enhed, og dermed ikke at nyværdien, men profittens andel af nyværdien, eller endnu mere præcist, at den akkumulerede profits andel, dvs. den andel der omsættes i produktionsmidler stiger i samme takt som produktiviteten allerede er forøget og endnu mere hvis produktiviteten yderligere skal forøges.

Dermed er kun sagt, at dette er betingelsen for at beskæftigelsen fastholdes, men ikke at profitraten dermed ikke falder, og dermed ikke at beskæftigelsen på lidt længere sigt kan fastholdes på dette niveau.

Der er altså her tale om, at forøgelsen af produktivkraften kræver for$\emptyset$ get indsats af kapital (fast) blot for forøgelse, og at den dermed forbundne nedgang $i$ anvendelsen af arbejdskraft $i$ forhold til en given kapital kræver for fastholdelse af værdiproduktet (og dvs. beskæftigelsen) en forøgelse af kapitalen, der er lige så stor som nedgangen i den mængde arbejde, der sætter en given kapital i bevægelse. ${ }^{30}$

Problemet består således i forholdet mellem stigningen i kapital/arbejde og den dermed forbundne produktivitetsstigning.

Forholdet mellem kapitalintensitet og produktivitetsstigningerne, kapitalproduktiviteten indebærer ceteris paribus (bla. lønkvoten) en tilsvarende ændring i profitraten og dermed - forudsat profitten investeres, hvad der må antages at være den »normale « langsigtede tendens - i akkumulationsraten. ${ }^{31}$ Eller med andre ord, den strukturelle arbejdsløshed, som her diskuteres af DØR angiver de fænomener, hvis sammenhæng nedenfor skal diskuteres og som betegnes som den langsigtede udvikling, trendudviklingen eller den strukturelle udvikling i kapitalforholdet.

Også hos DØR betragtes den aftagende vækst og beskæftigelsesproblemet som et profitproblem, men da som et problem om profitkvoten.

30. Den modgående bevægelse hertil er, at samme mængde arbejde (og dermed værdi) udtrykker sig i en større mængde brugsværdier (altså også produktionsmidler), og da det produktive konsum af arbejdskraften ikke vedrører værdien af produktionsmidlerne, men deres brugsværdi, modsvares produktivkraftsforøgelsen af en vækst i det »potentielle« arbejdskraftsforbrug ved en given kapitalværdi. Men da diskussionen vedrører forholdene på det empiriske plan, hvor kapital og arbejde måles i deres fysiske udtryk og ikke som værdier, modsvarer relationerne overfor de reale størrelsesforhold.

31. Den langsigtede tendens må være at investeringerne bevæger sig i samme retning som profitten, idet både investeringer og renter af kreditinvesteringer skal afholdes af profitten. Men det gælder kun ideelt, også på længere sigt kan den modsatte bevægelse mellem profitmasse og -rate ophæve sambevægelsen. 
»Den væsentligste størrelse ... er helt åbenbart reallønnen «, ${ }^{32}$ hvor reallønnen har en noget speciel betydning som forholdet mellem lønomkostninger og priserne på slutprodukterne for en virksomhed. Stigende realløn indsnævrer profitandelen, og forcerer dermed investeringer i nyt kapitalapparat, der genopretter forholdet mellem profit og løn. Med andre ord forcerer reallønstigninger produktivkraftudviklingen, men indsnævrer samtidig virksomhedernes nettoindtjening. Problemet er således et profitproblem i dobbelt forstand, på den ene side søges profitten forøget gennem nye investeringer, der frisætter arbejdskraft, på den anden side falder nettoprofitten, hvilket betyder faldende investeringer. Begge dele fører til arbejdsløshed. Selvom arbejdsløsheden er det samme som krisen hos DØR, så fastholdes dog profitten som årsag hertil. Men profitten som profitkvote, eller som merværdirate om man vil, profit i forhold til lønnen, altså merværdiens relation til sin kilde, ikke profitten i forhold til den kapital, der skal udlægges for at producere den under gældende betingelser. Kun såfremt lønnen stiger hurtigere end profitten består hos DØR et profitproblem, at forceringen af profitmassen fordrer overproportionale kapitaludlæg, reflekteres ikke her. Lønstigningerne er krisens årsag, og derfor er der ingen modsætning mellem strukturelle beskæftigelsesproblemer eller strukturkrise i den førstnævnte forstand og denne. Hos DØR er årsagen den samme og midlet mod den er det samme, lønstyring.

Fejlen hos DØR består derfor i, at de kun betragter fordelingen af nyværdiens masse, forholdet mellem lønsum og profitmasse. Det fald i profitraten, som teoretisk må antages at være baggrunden for det relative fald $\mathrm{i}$ profitmassen, har sin årsag i, at vejen ud af profitklemmen, hvad den så end er betinget af, under givne omstændigheder for enkeltkapitalerne er bundet til forcering af kapitalindsatsen for forøgelse af produktiviteten, og dermed ledsaget af fald i profitraten. Dermed er vi fremme ved de relationer, der er centrale i den kapitalistiske udviklingsproces, og som skal indgå i den empiriske analyse nedenfor, profitraten som akkumulationens drivkraft og tvangen til at søge ekstraprofitter, formidlet for enkeltkapitalerne gennem konkurrencen på hjemmemarkedet og på verdensmarkedet. ${ }^{33}$

32. op. cit. p. 56.

33. Også SØ'erne binder som vist diskussionen til profitklemmen, til profitkvoten og formår derfor ikke at kritisere DØR for andet, end at deres tal og sammenstillinger er politisk motiverede. Fejlen hos DØR er således ikke, som S $\emptyset$ 'erne mener, at deres opfattelse af strukturkrisen er selvmodsigende, men snarere, at den entydigt er bundet til samme faktor, lønnen, og ikke til det, der først stiller delingsforholdet som problem, forholdet mellem profittens masse og dens forudsætning i det eksisterende kapitalapparat. 


\subsection{Sammenfatning og præcisering af forudsætningerne}

For begge de refererede analyser gælder således, at krisen begrundes i en aktualisering af forhold, der altid har gjort sig gældende, hos $\mathrm{M} / \mathrm{V}$ »forholdet mellem løn, priser og produktivitet«, hos DØR »betalingsbalancen og konkurrenceevnen «.

Mens M/V's strukturelle forklaringer eller grundliggende forhold fortaber sig i uholdbare antagelser om konkurrenceudsatte vs. beskyttede sektorer, og hvor kritikpunktet bliver markedsmekanismens fallit og i sammenhæng hermed den utilstrækkelige statslige styringsindsats, koncentrerer DØRs forklaring sig om profitkvotens aftagen som det centrale forhold og peger på en række af de udtryk, som ledsager den faldende vækst, og som må forklares som resultater af den stedfundne akkumulationsudvikling.

Men hverken DØR eller M/V fremkommer med en forklaring på, hvorledes de langsigtede udviklingstræk udgør baggrunden for den nuværende krise, og der med heller ikke på hvad der har betinget dels det kraftige gennemslag og dels den lange varighed krisen har haft.

Heroverfor skal jeg fors $\varnothing$ ge at eksemplificere, at en formidling mellem den langsigtede udvikling, mellem de strukturelle akkumulationsbetingelser og akkumulationens cykliske gennemsættelsesform er nødvendig for at diskutere især den aktuelle krise.

Krisen kan kun forståes som et cyklisk sammenbrud, men en »ren cyklisk« analyse ville være for kortsigtet og utilstrækkelig, fordi krisen nok abstrakt er en sammenpresning af profitratens langsigtede fald, men konkret er et udtryk for, at den langsigtede tendens (til udvikling i kapitalstrukturen, og dermed til fald i profitraten) som har gjort sig gældende siden begyndelsen af 50'erne nu igen fremstår på overfladen som faldende profitrate og masse. Netop den langvarige prosperierende udvikling, som har været karakteriseret af, at akkumulationen har kunnet øge tempoet, trods faldende profitrate, har betydet sådanne ændringer i kapitalforholdet, at dybden af den nuværende krise kun kan forståes i sammenhæng med fraværet af tidligere dyberegående recessioner. Mattick fremstiller i virkeligheden problematikken klart: »Antager man nu, at der foregår en uophørlig progressiv kapitalakkumulation, så må merværdiratens og profitratens kompenserende, men modsatte bevægelser i sidste ende føre til en situation, som udelukker fortsat akkumulation. Mens merværdiraten må forøges enormt for at kompensere profitratens fald, formindskes den varia- 
ble kapital og så fremdeles overfor den konstante, og antallet af merværdiproducenter falder i forhold til den kapital, som skal værdiøges. Stadigt færre arbejdere må frembringe en stadigt større merværdi, for at producere bestemte profitter, til den allerede forhåndenværende kapital, hvad der gør den fortsatte ekspansion mulig. Der må uundgåeligt indtræde et punkt, hvor selv den højest mulige merværdimasse, der kan trækkes ud af den formindskede arbejderstand, ikke rækker til fremdeles at værdiøge den akkumulerede kapital. $\ll^{34}$

Den langvarige prosperitet, eller måske rettere fraværet af dyberegående renselseskriser, har netop præget den danske akkumulation i efterkrigstiden, og problemet for den empiriske analyse nedenfor bliver i forlængelse heraf at undersøge, hvorledes denne udvikling sætter betingelserne for krisegennemslaget, at fremstille, hvorledes krisen netop kun kan forståes som slutpunktet for den langsigtede udvikling, som det punkt hvor den under givne betingelser højest mulige merværdimasse ikke rækker til fremdeles at værdiøge den akkumulerede kapital, kort sagt som overakkumulationskrise.

Derfor er en analyse alene af den seneste cyklus utilstrækkelig for fremstillingen af krisen. Selvom profitratens tendens, med Matticks ord, ikke er »synlig i dens egen skikkelse, men i de foranstaltninger som sættes imod den, i de processer, som Marx opregner som tendenser, der modvirker profitratens fald. « ${ }^{35}$ Så er det netop tesen her, at de andringer i kapitalstrukturen, som betinger denne tendens' historiske realitet, lader sig eftervise empirisk, og at den aktualisering af profitratens fald, som udløser krisen, må forståes som resultat af, at de modgående faktorers ophævende indflydelse er udtømt. Videre, at uden den cykliske formidling af akkumulationen med dens overophedning, spekulation, etc. ville det voldsomme fald i profitraten, som indledte den aktuelle krise ikke være forståeligt.

Selvom en lang række modvirkende faktorer på kort som på langt sigt kan udskyde eller hæmme den strukturelle tendens' gennemslag i en faldende profitrate, betyder dette ikke, at den strukturelle tendens sættes ud af kraft, som et determinerende forhold, men at det må tages i betragtning, at dens gennemslag ikke nødvendigvis kommer til udtryk som et successivt fald i profitraten. Afgørende herfor er tillige markedsdvs. realiseringsbetingelserne.

34. P. Mattick, Kriser og kriseteorier, p. 46.

35. op. cit. p. 47. 
Dermed bliver ikke alene de langsigtede udviklingstrends, men tillige deres konjunkturelle formidling centrale for analysen af krisens gennemslag.

Det må derfor fastholdes, at de modgående faktorers evt. realt modvirkende indflydelse mht. rentabilitetsudviklingen alene betyder, at det strukturelle modsætningsforhold ikke til enhver tid kommer til udtryk i profitraten som fald, men derimod ikke, at det ophæves eller sættes ud af kraft som sattende vakstbetingelserne. Jeg skal vende tilbage hertil i tolkningen af de empiriske udviklingstræk, og der søge at vurdere om ændringerne i produktionsgrundlaget mht. kapitalsammensætningen grundlæggende har ændret betingelserne for ekspansion i produktionen.

Men dette vedrører i første række vækstbetingelserne forstået som forholdet mellem akkumulationsfondet og kapitalinvesteringerne, som bestemt af kapitalens sammensætning og omfang. Men reproduktionsprocessens kontinuitet vedrører ikke alene kvantitative relationer indenfor profitforholdet. De strukturelle ændringer sætter sig tillige igennem som forskydninger i den samfundsmæssige produktions sammensætning, forskydninger, som overhovedet skærper kravene til produktionens og dermed realisationens absolutte kontinuitet. De ændrede reproduktionsbetingelser træder frem som $\emptyset$ get »konjunkturfølsomhed « på den ene side og nødvendiggør på den anden side yderligere statens indgreb til sikring af denne kontinuitet, samtidigt med at de ændrer betingelserne herfor. De udtrykker sig altså på den ene side som realiseringsproblemer pga. forskydningen mellem produktionens afdelinger og den faldende profitabilitet, på den anden side som kontinuitetskrav med den større vægt kapitalproduktionssektoren antager. Dette skal jeg vende tilbage til senere, men her præcisere, at i analysen af den strukturelle udvikling må fastholdes

1. valoriseringen af den udlagte kapital som sættende vækstbetingelserne, og

2. denne udviklings udtryk i forudsætningerne for reproduktionens gnidningsfrie videreførelse og i kravene hertil.

På forhånd er imidlertid klart, at den danske akkumulation ikke foregår i et internationalt vakuum, men at den $\varnothing$ konomiske udvikling i DK tværtimod i afgørende grad har været bundet til udviklingen på verdensmarkedet.

Madsen/Vangskjærs og DØRs bekymring over den danske industris konkurrenceevne på verdensmarkedet, som er refereret i foregående afsnit afspejler således det reale moment, at den økonomiske udvikling i DK har 
været afhængig af udviklingen på verdensmarkedet, og bliver det stadig mere.

Afhængigheden har mindst to aspekter:

1. Den danske akkumulation er blevet mere afhængig i kraft af, at en voksende del af dens produktion realiseres på verdensmarkedet, og at modsvarende en voksende del af dens forbrug af konstant kapital importeres.

2. Den er tillige blevet mere afhængig i kraft af, at en voksende del af produktionen kun kan finde sted som verdensmarkedsproduktion, fordi produktionen skal finde sted i en målestok, der overskrider det nationale markeds konsumkraft.

Den første form for afhængighed kan belyses af en række karakteristiske udviklingstræk:

- industriens voksende eksportkvote, $35 \%$ af industriens produktion eksporteredes i $73 \bmod 25 \%$ i 65 .

- industriens voksende andel af den samlede eksport, og sammenhængende hermed den aftagende betydning af landbrugets eksport, som er konjunkturstabiliserende mere end industrien. Hermed er dog ikke sagt, at landbruget er af ringe betydning for den samlede udvikling, tværtimod kan man sige, at udgangspunktet i landbrugsproduktionen var og er et af dansk industris problemer, som har betinget den store andel nærings/nydelsesmiddelbranchen har af den samlede produktion, og som igen har betinget en større hjemmemarkedsproduktion end i andre mindre landbrugsprægede lande. Det betyder at den danske industris konjunkturelle bindinger er anderledes end eks. den vesttyskes do. hvor investeringsgodeproduktionen udgør en langt større del, idet konsummiddelproduktionen er bundet til massernes konsum, og dermed bundet til lønudviklingen.

- faldende selvforsyningsgrad (det gælder for alle industrilande) især mht. produktionsmiddelindustri (faldende fra 70-80\% i 50'erne til 30$40 \%$ i 70'erne), hvad der hænger sammen med den generelt gældende tendens til specialisering.

- endelig hænger det kroniske underskud på betalingsbalancen sammen med importens sammensætning (70-80\% består af råvarer og halvfabrikata og produktionsudstyr til industri), som delvist afspejler mangelen på basisproduktion.

Det afgørende forhold bag disse karakteristika er det begrænsede nationale marked, både mht. realisering af de producerede varer og som leverandør af produktionens elementer, herunder arbejdskraft. 
1. Markedets begrænsethed betyder at flere kapitaler må producere til eksport for overhovedet at producere rentabelt. Dette er en konsekvens af, at med den grad af specialisering, der er udviklet på verdensmarkedet, og med stigningen i kapitalsammensætningen kræver produktionen for at være rentabel en produktion af en vis størrelse, som i mange tilfælde overskrider det nationale markeds konsumkraft. Men det gælder for stort set alle kapitaler, at de må producere under de betingelser, der er udviklet på verdensmarkedet, og at der derfor ikke eksisterer egentlig beskyttede dele af industrien.

2. Det begrænsede og ringe koncentrerede nationale arbejdsmarked betinger eksistensen af små kapitaler. Ikke alene er der ikke afsætningsmuligheder, men der er heller ikke produktionsmuligheder for en højere koncentrationsgrad, uden at det ville medføre en kraftigt forøget konkurrence om arbejdskraften (hvad der vel lader sig gennemføre i krisetider, men hvor enkeltkapitalers beslaglæggelse af arbejdskraft i et stort lokal-område kun vanskeligt lader sig fastholde i højkonjunktur). Dette betyder tillige, at opdelingen af produktionen i deloperationer allerede har sat sig igennem, som opdeling i virksomheder med udpræget karakter af underleverandør. Som massiv krisestrategi for enkeltkapitalerne falder derfor divisionalisering og udspaltning af dele af produktionen til dels bort, eller bliver til nedlæggelse af hele virksomheder.

3. I sidste ende er det derfor det begrænsede nationale marked, der betinger den danske akkumulations afhængighed af verdensmarkedet. Denne afhængighed gør sig tilsvarende gældende for andre små lande (eks. Belgien og Holland, der eksporterer hhv. 43 og $46 \%$ af BNP mod 30\% for DK) endog i højere grad, og selv for så store lande som Frankrig gælder at markedet for produktionsmiddelindustrien er for lille for profitabel produktion, og at sammenhængende hermed, en »selvbærende konjunktur« kun kan tænkes for de få store industrilande (som BRD og USA).

Denne karakter af afhængighed sætter betingelserne for den danske akkumulation, og dermed for krisegennemslaget. Men den indebærer tillige at den danske økonomi er blevet mindre styrbar fra nationalt hold, og at de restriktioner den $\varnothing$ konomiske politik underordnes som følge heraf, i mange tilfælde gør den tilsyneladende modsigelsesfuld.

Jeg skal vende tilbage til betydningen af afhængigheden i det senere afsnit om krisens karakter. 


\section{Udviklingen i kapitalstrukturen efter 1950}

I det følgende afsnit skal udviklingen i den danske kapitalakkumulation, eller ændringerne i kapitalstrukturen fremstilles i det omfang, den dels sætter betingelserne for den seneste konjunkturcyklus og dels, formidlet heraf udg $\varnothing \mathrm{r}$ betingelserne for krisegennembruddet, og dermed de relationer, som krisen må fungere rensende $\mathrm{i}$ forhold til for at genfrembringe det forhold mellem den producerede nyværdi og den anvendte kapital, der gør yderligere anvendelse heraf profitabel. ${ }^{36}$

Som det væsentligste karakteristikum ved den kapitalistiske produktionsmådes udvikling, og det som skal stå i centrum for den empiriske unders $\varnothing$ gelse nedenfor, anses udskiftningen af levende arbejde med genstandsgjort, hvorved hovedvægten lægges på stigningen i den tekniske sammensætning og denne gennemslag i værdisammensætningen. Det karakteristiske moment ved kapitaludviklingen anses således ikke for at være stigningen i kapitaludlæg i forhold til arbejde slet og ret, men den stigning der udtrykker, at forøgelsen af produktiviteten finder sted gennem relativ vækst i den fixe kapital, eller i at »arbejdsmængden pr. produktenhed « aftager i forhold til den værdidel, der er overført fra produktionsmidlerne. Dette er den immanente udvikling i kapitalforholdet, der kommer til udtryk i profitratens tendens til at falde.

For at udtrykke dette forhold lader jeg kapitalintensiteten $\mathrm{K} / \mathrm{L}$ alene være bestemt af investeringer i maskiner og transportmateriel i forhold til anvendte arbejdstimer. ${ }^{37}$ Herved udtrykkes alene stigningen i den tekniske sammensætning, som forholdet mellem massen af kapital og massen af anvendt arbejde, idet der ikke tages hensyn til at sidstnævnte (L) som værdi udtrykker sig i en større mængde produkter. Der må derfor tages hensyn til væksten i den mængde produkter, det levende arbejde udtrykkes i i forhold til mængden af arbejdstimer, altså arbejdsproduktiviteten.

36. Jeg har derfor tilstræbt, så vidt muligt at lade oplysninger løbe frem til 74, men ikke i dette afsnit at forlænge disse til kriseårene. En væsentlig komplikation herved ville være, at den forringelse eller destruktion af værdi, krisen har til resultat ikke kan medreflekteres i de statistiske opgørelser (eks. i K) og de helt afgørende ændringer i kapitalforholdet derfor ville finde sted udenfor det synsfelt, der er anlagt her.

37. Om beregning af kapitalstok m.m., se Bredsdorff, Brinch og Hansen, Indkomstpolitik og kapitalakkumulation i Danmark, $i$ KURASJE 17, p. 51ff. De statistiske opgørelser er ligeledes taget herfra. 
Ideelt udtrykker dette altså forholdet mellem den indskudte fixe kapital og den nyværdi, der tilføjes i et omslag (her et år). Da ikke hele nyværdien indgår i valoriseringen af den udlagte kapital, men en del fradrages som udlæg til den variable kapital, tages højde herfor ved at reducere nyværdien med den andel, der tilfalder arbejdskraften som løn (angivet ved lønkvoten w). Sammenfattes dette i et enkelt udtryk fås kapitalrentabiliteten, ${ }^{38}$ der er bestemt som forholdet mellem arbejdsproduktivitet og kapitalintensitet ganget med profitkvoten (= den komplementære værdi af lønkvoten, 1-w), $\mathrm{pi}=\frac{\mathrm{Y} / \mathrm{L}}{\mathrm{K} / \mathrm{L}}(1-\mathrm{w})$

Som det fremgår af figur 1 er kapitalrentabiliteten taget over hele perioden (50-74) faldet, og dette fald må primært tilskrives faldet i kapitalproduktiviteten $\mathrm{Y} / \mathrm{K}$. Kun for de seneste 2-3 år skyldes faldet direkte fald i profitkvoten (1-w).

Betragtet nærmere udviser pi langt fra en ensartet bevægelsesretning, men lader sig differentiere i forskellige faser, mest markant er det kraftige fald $\mathrm{i}$ begyndelsen af 50'erne og i begyndelsen af 60'erne frem til 1967. Forudsætningerne for den seneste cyklus (67-74) er således et klart fald i rentabiliteten, som allerede siden begyndelsen af 60'erne (1962) har medført faldende investeringsrater.

Gennem hele perioden udviser kapitalintensiteten en næsten ubrudt stigende tendens, omend svagere i slutningen af 50'erne og fra 67-69 (se figur 1), hvilket betyder, at den фkonomiske vakst og den stigende arbejdsproduktivitet gennem hele perioden har sine forudsatninger $i$ stigende kapitalintensitet. Hele efterkrigstiden er således karakteriseret ved, at produktivkraftsforøgelsen finder sted gennem en forøget indsats af maskineri, gennem »udskiftning af levende arbejde med genstandsgjort «. Den meget svage stigningstakt i K/L i årene 68,69, og 70 og den lidt svagere stigning i begyndelsen af 70'erne må således tilskrives det profitratefald, som den faldende rentabilitet må udtrykke sig i.

Den stigende anvendelse af fast kapital i produktionsprocessen udtrykker sig på den ene side $\mathrm{i}$ faldende profitabilitet, som (det må i hvert fald anses for sandsynligt) faldet i pi frem til 67 kommer til udtryk

38. Det er ikke stedet her at behandle forholdet mellem rentabiliteten og profitraten (transformationsproblemet). Se dertil Altvater m.fl., Kapitalens udviklingsfaser og -tendenser, $i$ Kurasje nr. 12, samt Jens Brinch, Kapitalakkumulation i DK II, p. 117-118. 
Figur 1. Arbejdsproduktivitet, kapitalintensitet, kapitalproduktivitet og kapitalrentabilitet i dansk industri 1951 - 74

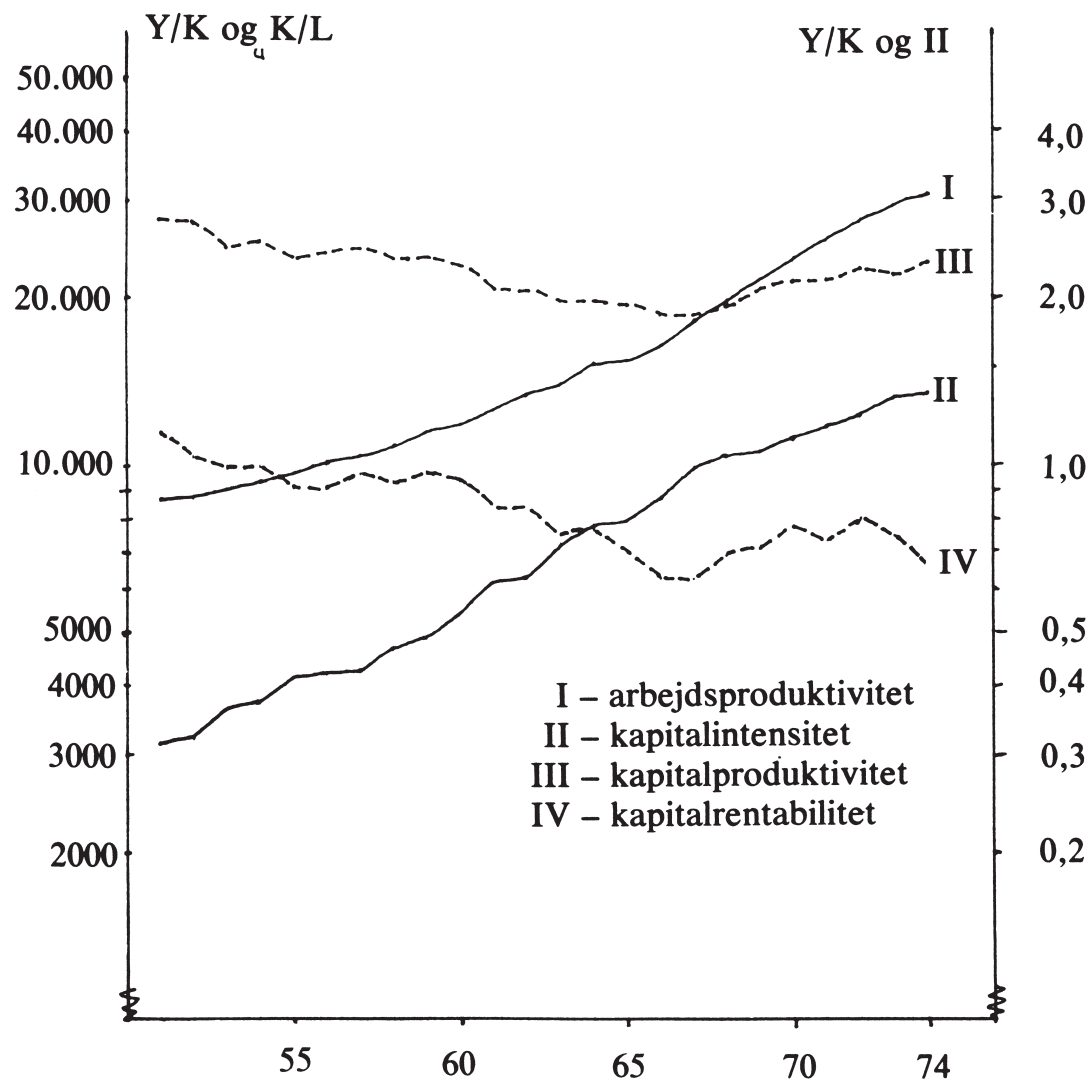

Kilde: Bredsdorff m.fl. op. cit. 
i, og på den anden side, hvad der er konsekvensen af dette forhold, i stigende profitmasse. Så længe stigningen i profittens masse er tilstrækkelig til at kompensere for faldet i profittens rate, dvs. så længe profittens masse stiger hurtigere end dens rate falder, kan akkumulationen fortsætte i uforandret tempo. Når dette ikke længere er tilfældet, når massen ganske vist kan kompensere, men $\mathrm{i}$ aftagende grad, når massen (og dermed akkumuleringen af cfix) vokser langsommere end raten falder, falder alt andet lige på længere sigt også vækstindikatorerne, økonomien stagnerer eller produktionen falder. Med andre ord, vi diskuterer symptomerne på, at krisen er på vej.

At dette også karakteriserer den danske udvikling og har gjort sig gældende allerede fra begyndelsen af 60'erne, skal jeg forsøge at gøre rede for.

Forholdet mellem pi's fald og den aftagende vækst i industriens produktionsresultat, kommer primært til udtryk i at:

1. trods stigende kapitalintensitet og stigende arbejdsproduktivitet falder stigningstakterne for nettoproduktionsresultatet.

2. forbruget af arbejdskraft (antal arb.timer) falder, og dermed falder tendentielt det ubetalte arbejde. ${ }^{39}$

3. investeringskvoterne både totalt og for maskininvesteringer falder. Sammenhængen mellem disse indikatorer skal jeg søge at fremstille nedenfor, og diskutere hvorledes de kan tolkes som udtryk for skærpelse af vanskeligheder mht. den kontinuerte reproduktion, og på den anden side, hvorledes de strukturelle ændringer i kapitalforholdet, som har betinget denne udvikling, og som fremstår heri, er selve skrankerne for akkumulationens fortsættelse. (m.a.o. hvorledes kapitalforholdet fremstår som en skranke for udvidelsen af produktionen, samtidig med at kapitalen som kapital fordrer den i endnu højere grad).

\subsection{Den aftagende vækst}

Selv om profitraten, som det fremgår af figur 1, er faldet kraftigt fra begyndelsen af 50'erne frem til recessionen i 67 har dette fald ikke givet sig udtryk i profittens masse, i det mindste ikke i den del heraf, der er akkumuleret. Tværtimod er investeringerne, eller hvad der er det samme akku-

39. Selvom den stigende udbytning kompenserer for faldet i L. 
mulationen af fast kapital steget år for år, i accelererende tempo frem til 62 $(65)^{40}$ som absolut størrelse. Det samme gælder, hvis man betragter deres andel af nyværdien (BFI) (og med konstant lønkvote tillige deres andel af profitten) som udtrykkes i investeringskvoten I/Y (se figur 2).

Figur 2. I/Y maskiner for industrien

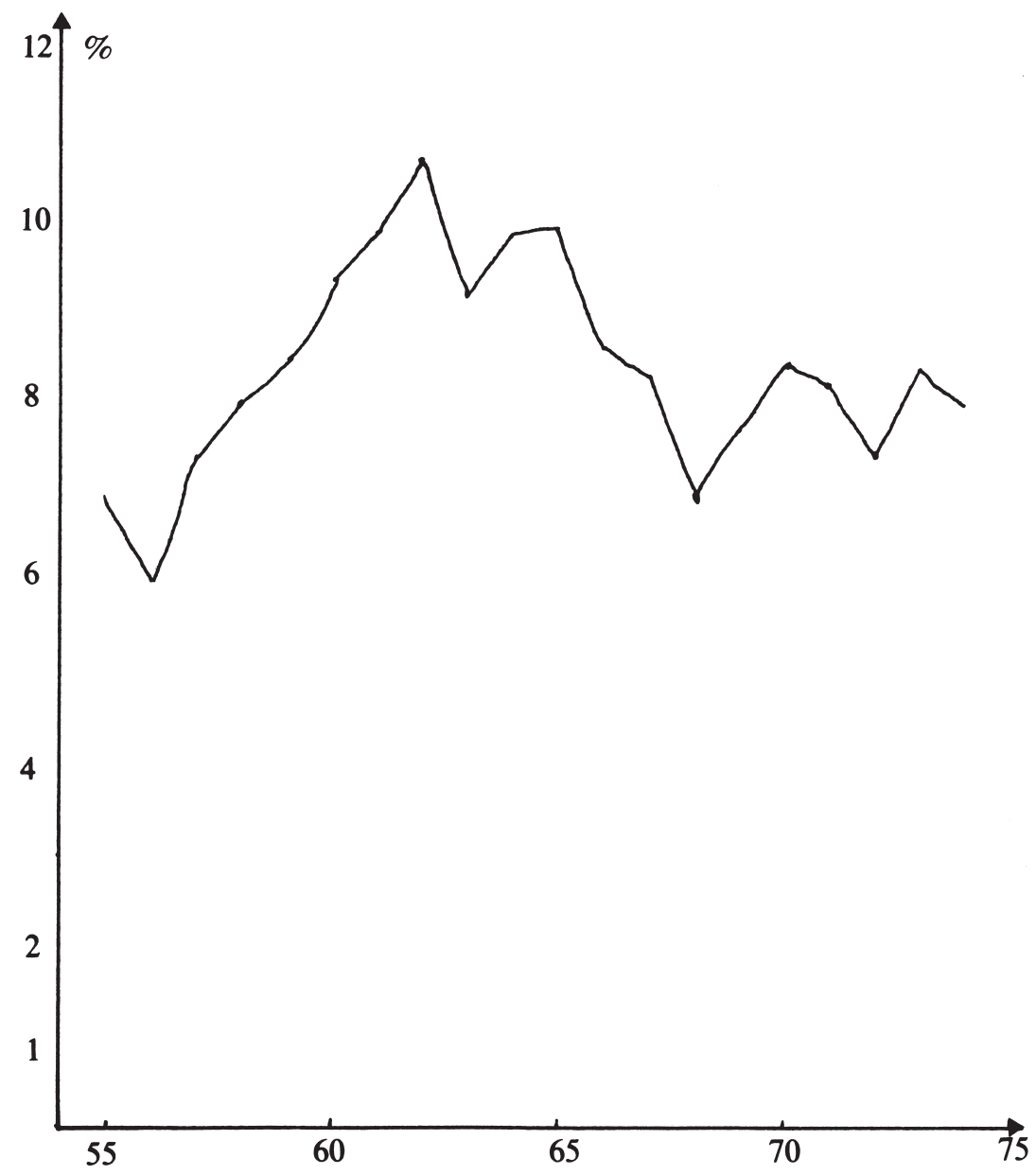

40. Det samme fremgår hos J. Brinch, Kapitalakk. I, p. 56, for de samlede investeringer. 
Her stiger den akkumulerede del ligeledes frem til 62 (65). Selvom dette ikke er tilstrækkeligt grundlag at slutte på, (bl.a. betyder kreditfinansiering af investeringerne stadigt mere, hvad der udtrykker at profitmassen ikke stiger nok) så antyder disse sammenhænge dog:

1. at vaksten i profittens masse for en tid har kunnet kompensere faldet i profitraten, at altså profitratens fald ikke i sig selv fører til fald i akkumulationen, tværtimod forstærker de samme faktorer, der fremkalder faldet i raten væksten i massen og dermed i akkumulationens absolutte omfang, men tillige i dens relative del. Teoretisk og tilsyneladende heller ikke empirisk er der således nogen grund til at antage et entydigt sammenfald mellem fald i profitraten og krisen. Først når faldet i profittens rate ikke kompenseres af stigningen i profittens masse, og absolut når yderligere investeringer ikke medfører nogen tilvækst i profitmassen, indtræder krisen med sikker nødvendighed. At den historisk kan indtræde tidligere skal kun bemærkes her. ${ }^{41}$

2. Denne sammenhæng antyder tillige et af den danske industris problemer i 50'erne, at industrien som helhed var for »svag «, og det vil væsentligst sige for lille, til selvstændigt at igangsætte en prosperierende akkumulation. Dette må tillige ses i sammenhæng med det begrænsede nationale marked, som på daværende tidspunkt langt hen var markedet overhovedet. Sagt med andre ord, de enkelte kapitaler var med få undtagelser for små og markedet var for lille til, trods en høj profitrate, at sikre en økonomisk vækst og til at akkumulere i nævneværdigt tempo.

Den danske industri var fra begyndelsen af 50'erne præget af en tilbagestående kapitalstruktur, som har sin rod dels i 30'ernes protektionisme og dels i krigens derationalisering.

Strukturrationaliseringen i 50'erne ${ }^{42}$ (den relative vækst i virksomhedsstørrelse angivet i forhold til beskæftigelsen), må betragtes som en af de faktorer, der sammen med væksten i kapitalernes størrelse (kapitaludlægget) har betinget stigende vækstrater trods faldende profitabilitet. Altså at koncentrationen har fundet sted i to henseender, a) antal beskæftigede, og b) kapital fixe.

41. Nemlig når det under de givne historiske betingelser ikke er muligt (f.eks. af politiske grunde) at forøge profitmassen tilstrakkeligt for den industrielle kapital. Renten som undergrænse for profitraten, det statslige merværdiforbrug etc. spiller ind her, som sættende de historiske grænser for akkumulationens forløb.

42. Antal virksomheder faldt med ca. $22 \%$ fra 50 - 58, mens antal beskæftigede pr. virksomhed steg med 36\%, se Søren Kjeldsen-Kragh: Specialisering og konkurrenceevne, p. 31. 
Modsat i 60'erne: her er rationaliseringen stagneret, monopoliseringen har nærmest været kapitalistisk regressiv mht. ${ }^{43}$ antal beskæftigede/virksomhed.

I forhold til 50'erne er vækstraterne for 60'erne kraftigt stigende:

Tabel 1. Væksten i industriens BFI (faste priser)

\begin{tabular}{|c|c|c|c|}
\hline & $50-58$ & $58-66$ & $66-74$ \\
\hline$\%$ vækst i BFI & 23,1 & 74,4 & 58,2 \\
\hline
\end{tabular}

Kilde: Bredsdorff m.fl. op.cit.

der som resultat må ses som følge af stigende kapitalsammensætning og absolut vækst i værdiproduktet (stigende beskæftigelse og antal arbejdstimer).

\subsection{Uddybningen af modsæatningerne i kapitaludviklingen}

Men dermed er de lyse tider for kapitalekspansionen tilsyneladende forbi. Fra det foreløbige højdepunkt i 65 peger stort set alle indikatorer på skærpelse af modsætningerne i akkumulationen.

Trods fortsatte stigninger i K/L fra midten af 60'erne (som udadtil delvist skyldes fald i L, men som på længere sigt må modsvares af en real stigning i kapitalindsats i forhold til levende arbejde, altså at stigningen udtrykker kun på kort sigt overkapacitet, men på lidt længere sigt udskiftning af menneskelige arbejdsfunktioner med maskinelle) og på trods af ekstraordinært store stigninger i arbejdsproduktiviteten (sml. figur 1, hvoraf fremgår at $\mathrm{Y} / \mathrm{L}$ accelererer efter 67) falder stigningstakten for værdiproduktet - og med konstant profitkvote også stigningstakten for profitmassen - hvilket udtrykker at akkumulationen ikke længere er kraftig nok til at fastholde beskæftigelsen, og dermed væksten i værdiprodukt og merværdimasse.

Akkumulationsbetingelserne efter 65 er derfor fundamentalt forskellige fra betingelserne før 65. Skal merværdimassen forøges, kan det

43. Sml. Bredsdorff.m.fl. op. cit., s. 16f. 
kun finde sted gennem produktion af relativ merværdi, og stigningen i merværdiraten skal være større end den tilbagegang i merværdimassen, der følger af faldet i beskæftigelsen. Dermed er vi inde i diskussionen omkring profitratens faldende tendens og den kompenserende virkning af væksten i merværdiens masse gennem sænkning af arbejdskraftens værdi. ${ }^{44}$ Med baggrund i denne diskussion kan problemstillingen her præciseres yderligere. Jo mindre arbejdskraftens værdi allerede er, jo mindre altså den nфdvendige del af arbejdsdagen er, jo mere skal produktivkraften forøges for at frembringe en stigning i merværdiens rate, der med hensyn til merværdiens masse kompenserer for et givet fald i den samlede mængde arbejde (betalt som ubetalt). Dette kan belyses med et eksempel:

Er antal arbejdere 100, det betalte arbejde 4 timer og merarbejdet 4 timer og faldet i beskæftigelsen 1\%, skal produktiviteten for at frembringe samme merværdi (nemlig 400), dvs. for at sænke arbejdskraftens værdi tilstrækkeligt, forøges med $1 \%$. Er forholdet $\mathrm{m} / \mathrm{v}$ lig $7 / 1$ betyder fald $\mathrm{i}$ antal arbejdere på 1\% et fald i merværdimassen på 7 (til 693) og de 100 betalte arbejdstimer skal nu sænkes til 93, altså en forøgelse på produktiviteten med mindst $7 \%$, eller med andre ord forøgelsen af produktiviteten skal stå $i$ omvendt forhold til den del det nфdvendige arbejde udg $\phi r$ af hele arbejdsdagen. Da arbejdskraftens værdi med stigningen i produktiviteten sænkes år for år, eller omslag for omslag, betyder en konstant faldende tendens i beskæftigelsen at produktivitetsforøgelsen må stige progressivt. Dette på den ene side.

På den anden side er klart, at en stigning i produktiviteten primært er betinget af en stigning i genstandsgjort i forhold til levende arbejde, altså af en stigende organisk sammensætning, indiceret ved K/Y. Med stigende $\mathrm{K} / \mathrm{Y}$ (eller faldende $\mathrm{Y} / \mathrm{K}$ ) skal produktiviteten stige progressivt for at fastholde forholdet mellem forøgelsen af merværdiens masse og væksten i kapitalsammensætningen, altså for at opretholde en konstant profitrate, udtrykt i værditermer, fordi den del af arbejdsdagen, der er betalt udg $\varnothing \mathrm{r}$ en stadigt aftagende del. Hertil kommer, kan nu tilføjes, at med konstant faldende arbejdskraftsforbrug skal ligegyldigt i hvilken retning kapitalsammensætningen bevæger sig, produktiviteten stige progressivt alene for at fastholde mervardimassen. Disse to forhold er de egentlige vanskeligheder

44. Sml. K. Marx, Grundrids p. 223 - 230. 
og den uoverstigelige modsætning den kapitalistiske produktion er bundet til, og som må komme til udtryk på samfundets overflade som stagnation eller krise. ${ }^{45}$

At det ikke lader sig gøre enkeltvist at estimere de elementer, der indgår i disse forhold (merværdi, merværdirate, arbejdskraftens værdi) umuliggør ikke en belysning af krisetendenserne. Hensigten her er ikke at give eksakte »termometerangivelser « af valoriseringsvanskelighederne, men at påpege de skarpelser og fordybningen af modsatningerne som en given udvikling i kapitalforholdet fører med sig, og det er denne (udviklingen i kapitalforholdet) vi vil søge at beskrive her for at give empirisk baggrund for profitproblemerne. Forklaringerne på de aktuelle sammenbrud i akkumulationen må så fra denne side hente stof i de teoretiske eksplikationer som danner substansen i forklaringen af kapitalstrukturen.

Vi kan derfor alene forsøge at undersøge om udviklingsretningen svarer til de forudsætninger, der er fremstillet abstrakt mht. fastholdelsen af profitrate og -masse.

Betragtes udviklingen fra 1965 - 74:

45. De indikationsmæssige problemer i denne sammenhæng fremstår af, at merværdiens størrelse som værdi og merværdiraten ikke lader sig estimere, til dels pga. manglende skelnen mellem produktivt og uproduktivt arbejde i det statistiske materiale, og dels fordi merværdiens fordeling ikke lader sig efterspore. Det betyder, at vi ikke kan diskutere ændringer ud fra merværdien eller merværdiraten, men må tage udgangspunkt i arbejdskraftens værdi og diskutere forøgelsen af merværdimassen i forhold til sænkningen af denne og vurdere forøgelsen i forhold.til faldet i beskæftigelsen og stigningen i K/Y.

Arbejdskraftens værdi som udgangspunkt er her indikeret ved reallønnen et givet år, og ændringerne i arbejdskraftens værdi som forholdet mellem udviklingen i reallønnen og produktiviteten. Der kan således ikke blive tale om nogen angivelse af værdien absolut, men kun af ændringerne heri, men også her er bestemmelsen yderst mangelfuld. Det værdibegreb, der her opereres med er en art »objektiv værdi«, en bestemmelse, som alene tager hensyn til bestemmelsen af værdiændringerne, som de udspringer af produktionen, men ikke medflekterer, at arbejdskraftens værdi tillige er bestemt af politiske forhold, af klassernes styrkeforhold. Når jeg alligevel tillader mig at bruge reallønsudvikling og produktivitet som indikator, er det fordi den tager udgangspunkt i den opnåede $1 \varnothing n$ og altså ikke diskuterer hvad der har bestemt denne, og dermed ikke hvad der har bestemt vardien. 
Tabel 2. Udviklingen i antal arbejdstimer, realløn og produktivitet i industrien fra $65-74$

\begin{tabular}{|l|c|c|c|}
\hline & 65 & 74 & $\%$-vækst 65-74 \\
\hline antal arb.timer & 628,5 & 526,5 & $-20,6$ \\
\hline produktivitet & 16.091 & 30.769 & 91,2 \\
\hline realløn & 9,30 & 14,36 & 54,4 \\
\hline
\end{tabular}

Kilde: Bredsdoff m.fl. op.cit.

Her er ingen tvivl om, at produktiviteten er vokset langt kraftigere end reallønnen, og sandsynligvis har forskellen mellem disse været stor nok til at kompensere tilbagegangen $\mathrm{i}$ antal præsterede eller fra kapitalens side antal opsugede arbejdstimer. Men denne konstatering alene kan ikke belyse problematikken som en fremadskridende udvikling af modsætningen mellem forøgelse af udbytningsgraden og indskrænkningen af grundlaget for merværdiens produktion.

Betragtes udviklingen år for år fra 1960 - 75 ser sagen anderledes ud:

Tabel 3. Forskellen mellem vækst i produktivitet (dY/L) og vækst i realløn $(d R w)$ og procentuel vakst $i$ antal arbejdstimer

\begin{tabular}{|l|c|c|c|c|c|c|c|c|c|}
\hline & 60 & 61 & 62 & 63 & 64 & 65 & 66 & 67 & 68 \\
\hline dY/L-dRw & $-0,4$ & $-1,8$ & 3,6 & 0,4 & 4,8 & 0,0 & 1,8 & 8,7 & 7,0 \\
\hline$\%$-vækst i L & 6,9 & $-1,0$ & 2,8 & $-2,5$ & 2,4 & 1,0 & 0,1 & $-6,5$ & $-3,0$ \\
\hline
\end{tabular}

\begin{tabular}{|l|c|c|c|c|c|c|c|c|c|}
\hline & 69 & 70 & 71 & 72 & 73 & 74 & & & \\
\hline dY/L-dRw & 1,1 & 3,4 & $-0,2$ & 4,1 & $-0,1$ & 2,2 & & & \\
\hline$\%$-vækst i L & 3,3 & $-1,8$ & $-4,2$ & $-1,0$ & $-1,5$ & $-2,5$ & & & \\
\hline
\end{tabular}

Kilde: Bredsdoff m.fl. op.cit. 
Figur 3. Forskellen mellen vækst i produktivitet og vækst i realløn, toårs gennemsnit

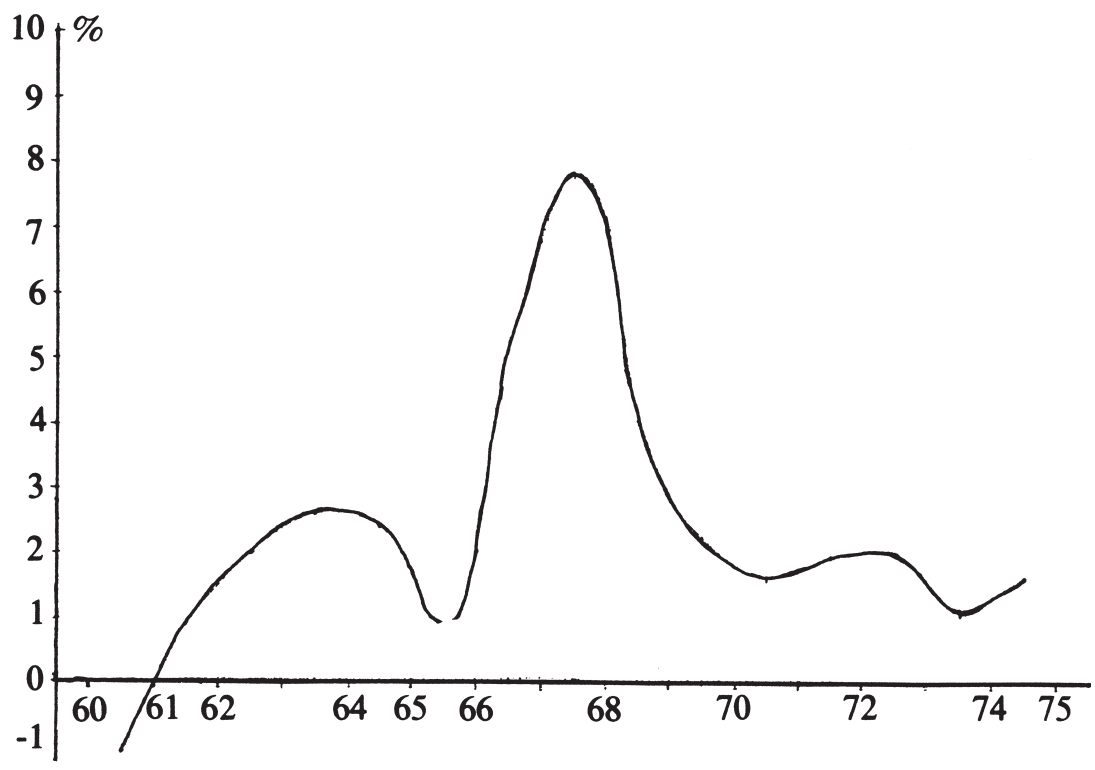

Af figur 3 fremgår, at »sænkningen af arbejdskraftens værdi $\aleph^{46} \mathrm{ikke}$ viser nogen stigende tendens i den betragtede periode, nok i begyndelsen af 60'erne, men ikke siden 1967. Dermed skarpes med hensyn til forфgelsen af mervardiraten problemerne ved kapitalekspansionen (idet forudsætningen for fastholdelse af profitraten ved stigende kapitalsammensætning var, at sænkningen af arbejdskraftens værdi skulle finde sted i voksende omfang. ${ }^{47}$

Betragter vi derefter sammenhængen mellem »sænkningen af arbejdskraftens værdi « og tilvæksten i beskæftigelsen, ser vi, at kun indtil 1970 har differencen mellem produktivitetsstigning og reallønstigning (»sænkningen af arbejdskraftens værdi «) været større end tilbagegangen i beskæftigelsen. Efter 1970 har tilbagegangen $i$ antal arbejdstimer varet st $\phi r r e$ end »sankningen af arbejdskraftens vardi og hertil kommer at denne,

46. Som er forskellen mellem vækst i produktivitet (d Y/L) og vækst i realløn (dRw). Er forskellen mellem disse større end o, er »arbejdskraftens værdi« faldende og vice versa.

47. At der ikke i hele tidsrummet er tale om stigende kapitalsammensætning (ikke fra 67-71) betyder kun, at problemet udskydes. Fra $71 \mathrm{og}$ frem gør det sig påny gældende. 
som ovenfor nævnt, ikke viser nogen stigende tendens. Dette må betyde, at mervardien stagnerer.

Sammenfattende herpå skulle vi kunne konkludere:

1. Den stigende tendens i arbejdskraftsværdisænkningen, som ifølge vore teoretiske forudsætninger skulle være tilfældet har ikke fundet sted. Hvis ikke $\mathrm{Y} / \mathrm{K}$ er konstant eller stiger tilsvarende betyder det et fald $i$ profitraten.

2. Fra begyndelsen af 70'erne har mervardimassen stagneret, hvad der sammen med stigende kapitalsammensætning betyder fald i profitabiliteten. Vi kan præcisere fænomenet fra 72 nærmere: profitraten er faldet, og den størrelse, som skulle have vist en modsvarende stigning, profitmassen er stagneret, der er med andre ord tale om overakkumulation (og ydermere fra produktionssiden absolut overakkumulation for totalkapitalen) ${ }^{48}$

3. Derimod kan der ikke herske nogen tvivl om, at udbytningen er for$\emptyset$ get kraftigt. Mens reallønnens andel af produktionen pr. arbejdstime i 1965 udgjorde 58\%, var dens andel i 1974 formindsket til 47\% eller en formindskelse med næsten $20 \%$. Hertil kommer den forøgelse af det uproduktive arbejde, som finansieres via en omfordeling af merværdien, der ikke kommer til syne i disse tal, men som indicerer, at udbytningen er forøget endnu kraftigere. Men vi kan slå fast, at allerede $i$ produktionen kommer en kraftig forøgelse af udbytningen til syne, men som vi så ovenfor ikke kraftig nok til at undgå profitratens fald.

\subsection{Konsekvenserne af den aftagende akkumulation}

Ikke alene den absolutte vækst i profitten er for lille til at fastholde beskæftigelsen, men langt mere den relative vækst i den akkumulerede profit (investeringerne) er i forhold til stigningen i kapitalintensiteten for lav til at fastholde det samlede værdiprodukt gennem fastholdelse af beskæftigelsen. Mens »prisen pr. arbejdsplads«, det vil her sige det nødvendige kapitaludlæg pr. arbejdstime, som afspejler kapitalintensiteten, fra 64-71 (altså 7 år nogenlunde svarende til investeringernes levetid) vokser med $45 \%$, stiger investeringerne i samme tidsrum kun med 23\%

48. Fra produktionssiden, idet der her kun er tale om den »objektive værdibestemmelse«. 
(for $65-72$ er tallene $37 \%$ og 12\%). Altså investeringerne stiger kun halvt så meget (eller mindre) end det er nødvendigt for at beskæftige samme antal arbejdstimer. Konsekvensen har været faldende arbejdstimeforbrug og efterhånden faldende beskæftigelse, som må komme til udtryk $i$ en stigende »strukturel « arbejdsløshed, med mindre den frisatte arbejdskraft og tilgangen til arbejdsmarkedet opsuges af uproduktive sektorer.

Selvom det sidste har været tilfældet i DK (og til dels i andre vestlige lande), således beskæftiger liberale erhverv, administration m.v. 20,5\% af arbejdsstyrken i 70 mod 15,6\% i 65, så kommer den vigende beskæftigelse $\mathrm{i}$ industrien til udtryk i niveauet for arbejdsløsheden: ${ }^{49}$

Tabel 4. Antal ledige i \% af forsikrede

\begin{tabular}{ccccccccccc}
\hline & 65 & 66 & 67 & 68 & 69 & 70 & 71 & 72 & 73 & 74 \\
\hline \%-ledige & 2,3 & 2,6 & 3,2 & 5,2 & 4,4 & 3,6 & 4,2 & 3,9 & 2,9 & 5,5 \\
\hline
\end{tabular}

Kilde: Statistisk Tiårsoversigt 1976.

Selv i 1973, der normalt betegnes som et år med fuld beskæftigelse ligger arbejdsløsheden væsentlig højere end i midten af 60'erne.

Den stigende strukturelle arbejdsløshed skyldes derfor ikke, som DØR (i april-rapporten fra 76) synes at mene, stigningerne i produktivitet eller for lille vækst i BFI i forhold til produktivitetsstigningen, men at akkumuleringen af profit er for lille $\mathrm{i}$ forhold til stigningen i den nødvendige kapitalindsats. Denne for lille akkumulering har sin baggrund i den faldende profitrate og væsentligst, at stigningen i profitmassen ikke laengere er tilstraekelig til at modvirke faldet $i$ profitraten.

49. Samme fænomen gør sig gældende i Sverige med større styrke, her skjules problemet dog delvist af, at en del af den »strukturelle arbejdsløse« er beskæftiget med »arkivarbejde«. Videre har det her givet sig udslag i en stigning i den »hypertunge« ledighed, dvs. i langtidsarbejdsløshed, hvor beskæftigelsesvanskelighederne tilskrives inadækvate kvalifikationer i forhold til stillingsudbud. Selvom dette er et væsentligt karakteristikum, angiver det alene hvilke dele af arbejderklassen, der udstødes, det stigende niveau i arbejdsløsheden må derimod primært ses som betinget af den manglende akkumulationskraft, og i forbindelse hermed skærpelsen af konkurrencen, forøget pres på enkeltkapitalerne for intensivering og opskruning af jagten på ekstraprofitter via stigende kapitalindsats i produktionen. 
Mens investeringerne i maskiner efter nedgang fra 65-67 atter stiger frem til 73/74 i absolutte størrelser kommer investeringsraten aldrig op på niveauet fra 65, tværtimod falder raten som tendens i hele perioden efter 65 (se fig. 2).

Mht. investeringerne gør to forhold disse betragtninger relevante:

1. Skiftet i akkumulationsformen fra ekstensiv til intensiv akkumulation, som er påpeget af andre, forstærkes yderligere efter 65 og især i slutningen af perioden. Således udviser maskininvesteringernes andel af de samlede investeringer en stigende tendens, som det fremgår af tabel 5, hvilket betyder, at tendensen til, at akkumulationen finder sted som udskiftning af levende arbejde, forstærkes gennem hele perioden og især i den sidste del. Men intensiveringen af akkumulationen finder nu ikke sted primært begrun-

\section{Tabel 5. Maskininvesteringernes procentvise andel af de samlede investeringer $\mathrm{i}$ industrien (faste priser)}

\begin{tabular}{|l|c|c|c|c|c|c|c|}
\hline & 60 & 61 & 62 & 63 & 64 & 65 & 66 \\
\hline$\%$-andel & 44,7 & 45,4 & 50,4 & 52,6 & 56,1 & 54,2 & 55,6 \\
\hline
\end{tabular}

\begin{tabular}{|l|c|c|c|c|c|c|c|}
\hline & 67 & 68 & 69 & 70 & 71 & 72 & \\
\hline$\%$-andel & 58,6 & 60,9 & 58,8 & 60,1 & 67,5 & 66,7 & \\
\hline
\end{tabular}

Kilde: egne beregninger efter: Jarn Schauby: Kapitalbehov i industrien. p. $321 i$ Kapital og Produktion., red. af Niels Groes.

det i beskæftigelsesskranker, men formidlet af den skærpede konkurrence, som den næsten sammenfaldende overakkumulation udtrykker sig i nationalt som internationelt. Tvangen til kapitalintensivering af produktionen som følge $\mathrm{af}^{50}$ beskæftigelsesskranker finder sted når markedet er ekspanderende, når efterspørgslens »overskud « overfor udbuddet gør konkurrencen »mindre skarp«, til en konkurrence om forøgelsen af profitmassen, altså i faser hvor kapitaler med størst relativt arbejdskraftsforbrug kan videreeksistere. Denne tilstand forsvinder med højkonjunkturens stagnation, hvor intensiveringen af produktionen bliver forudsætning for fastholdelsen af markedsandelen, og dermed profitandelen, med en faldende profitrate. De samme faktorer, 50. Sml. J. Brinch, Kapitalakk. II. 
som for enkeltkapitalerne muliggør, at deres andel af den samlede profit, deres individuelle profitrate, ikke falder under gennemsnittet, og som kun der igennem momentant sikrer deres eksistens, fremmer gennemsnittets fald og truer derigennem alle kapitalernes eksistens. Denne nødvendighed formidles for enkeltkapitalerne af den skærpede konkurrence, men konkurrencens skærpelse er på sin side kun udtryk for, at tendensen allerede er virksom, at intensiveringen allerede har fundet sted i et omfang, der har fået profitraten til at falde. Og det er en udvikling, der rammer alle kapitaler, fordi tvangen til intensivering i denne fase er et udtryk for, at der forbruges mere arbejde til produktionen, end det samfundsmæssigt er nødvendigt, at med andre ord ikke alt det arbejde, der materialiseres, er værdisættende, hvad der først viser sig i realisationsfasen som skærpet konkurrence og destruktion af »individuelt sat værdi«, som fald i de individuelle profitrater.

I denne forstand formidler konkurrencen for enkeltkapitalerne den »gennemsnitligt nødvendigt arbejdstid « som bestemt af den betalingsdygtige efterspørgsel, og disse nye gennemsnit er samfundsmæssigt bestemte og formidles som sådanne for enkeltkapitalerne. Dannelsen af den gennemsnitlige profitrate er derfor ikke kun et fremstillingsproblem i Kapitalen, men den aktive proces, der »bag om ryggen « på enkeltkapitalerne sætter nye gennemsnit som tvang til omkostningsreduktion. Der er derfor ikke tale om konkurrenceudsatte og ikke-konkurrenceudsatte brancher, ${ }^{51}$ men om forskellige brancher »hvis « marked i forskellige tidsrum kan være mere eller mindre ekspanderende i forhold til produktionskapaciteten, men hvor krisen (i absolut forstand) tvangsmæssigt for alle kapitaler gennemsætter det nye samfundsmæssige gennemsnit.

2. Den postulerede sammenhæng mellem produktivkraftsforøgelse og kapitalintensivering, som jeg fremførte tidligere lader sig også eftervise empirisk.

Ifølge figur 4 har den stigende vækst i produktiviteten mod 60'ernes slutning været betinget af en tilsvarende vækst i maskininvesteringernes andel af nettoproduktet, med et karakteristisk efterslæb (på 2-3 år) og en lidt ringere stigningstakt. Dette modsvares af en tiltagende stigning i kapitalintensiteten i samme periode med konsekvens, at det sammenfattede udtryk, kapitalproduktiviteten, har været faldende. Med faldende investeringsrate efter 65 falder med nogle års forsinkelse tillige vækstraten for produktivitetsstigningerne.

51. Som hos Madsen og Vangskjær, jvnf. kritikken heraf tidligere. 
Figur 4. Y/L og I/Y for industrien

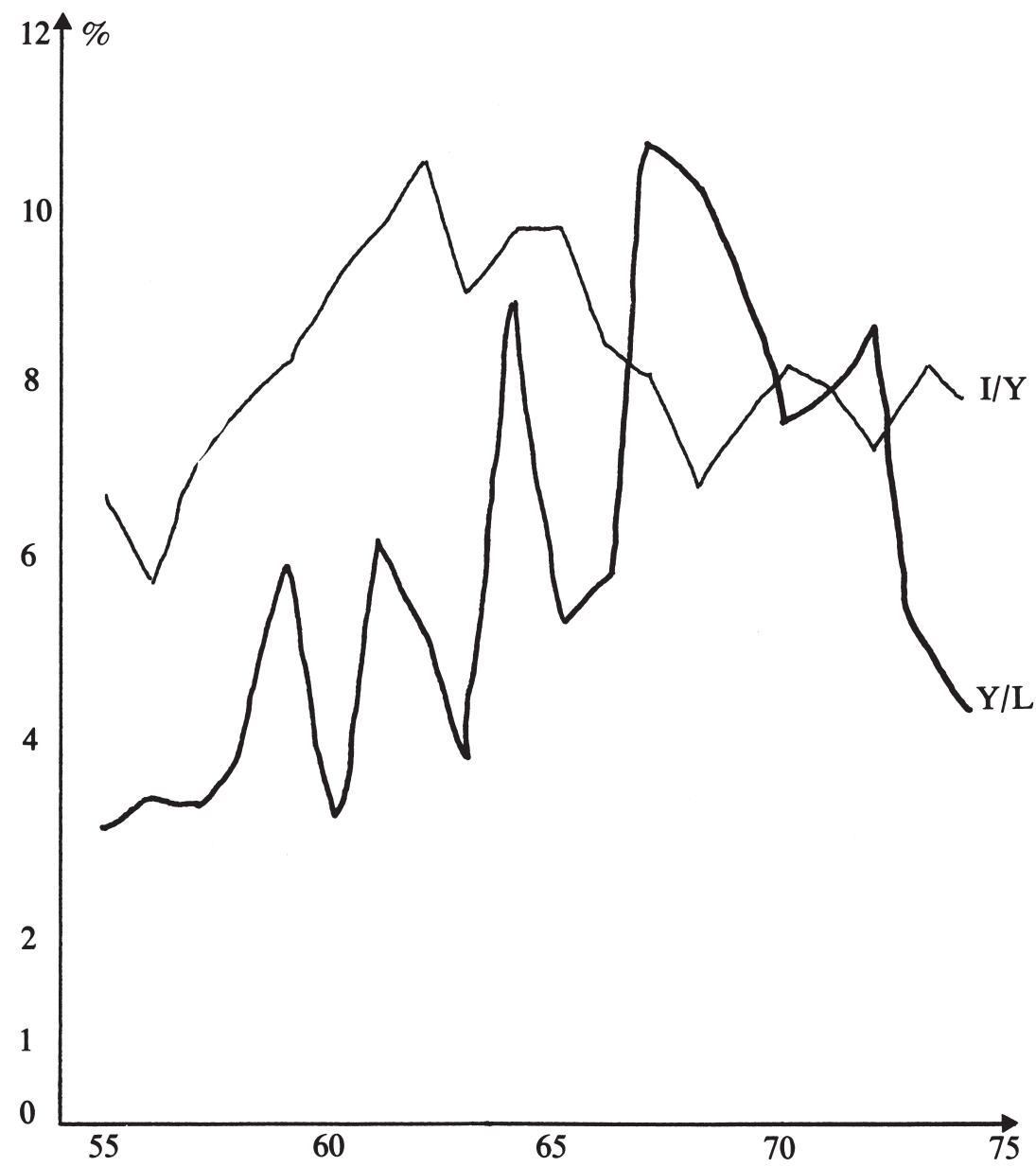

Uden at fortolke dette ind i en simpel produktionsteknisk sammenhæng kan vi fastholde vores tidligere konklusion om, at produktivitetsstigningerne gennem hele perioden er betinget af og bundet til stigninger i kapitalens tekniske sammensætning (indiceret ved kapitalintensiteten), og at derfor fastholdelse af vaksten i produktionsresultatet med faldende arbejdskrafts- 
forbrug, som i slutningen af 60'erne og begyndelsen af 70-erne kun kan sikres gennem stigende investeringskvoter. ${ }^{52}$

Heri adskiller udviklingen i DK sig ikke fra udviklingen i flere andre vesteuropæiske lande, bla. BRD. Konklusionen herpå kunne være den samme som hos Semmler/Hoffmann: »så betyder dette, at en voksende kapitalindsats er nødvendig for at frembringe en lige så stor tilvækst i nettoproduktet. Den $»$ marginale kapitalkoefficient stiger «. ${ }^{53}$

Men dette er, som det fremgår af både figur 2 og figur 1 ikke ubetinget tilfældet i DK. Den afgørende forskel fra den tyske udvikling er, at den »marginale kapitalkoefficient « ikke stiger, men at omvendt den stigning i produktiviteten som fandt sted i 60 'ernes begyndelse fortsætter, ikke alene i kriseårene 67 og 68, men fastholdes på et højt niveau frem til 72. Det afgørende træk ved den danske udvikling som kommer frem i stigningen i kapitalproduktiviteten (og som også viser sig i rentabiliteten) indtil 1972 er på kapitalsiden den lange fase med sekundærinnovationer, som på arbejdssiden kommer til udtryk i forøget arbejdsproduktivitet og -intensitet uden tilsvarende forøgelse af kapitalintensiteten (se figur 1).

En væsentlig del af produktivitetsstigningen i denne periode skyldes sandsynligvis, at de forhold som betinger, at en stigning i arbejdsintensiteten lader sig gennemføre i 67/68, også i årene efter krisen er virksomme. Årsager hertil skal jeg ikke komme ind på, men den med det danske lønsystem forventelige afsmitning af tempo- og især ikketeknologibårede produktivitetsforøgelser i lønforøgelser synes for årene 69-71 at bekræfte, at intensiveringen har været fremherskende. ${ }^{54}$

Som tidligere nævnt kan de modgående faktorer til profitratefaldet, som udløses af dette, og hvis gennemsættelsesbetingelser i høj grad hænger sammen med styrkeforholdene mellem klasserne (og for DK med reformismens styrke i arbejderbevægelsens organisationer), kun udskyde, men ikke ophæve virkningen af den forøgede kapitalindsats mhp. profitraten. Dette viser sig med al tydelighed: de ekstraordinære forbedringer i arbejdsproduktiviteten omkring 70 ophфrer stort set fra 72, og betingelserne for den kapitalistiske

52. Det samme fremgår hos J. Schauby: Kapitalbehov i industrien, p. 324 i Nils Groes, Kapital og produktion. For at fastholde en 5\% vækst frem til 1980, skal bruttoinvesteringskvoten op på $20 \%$ $\bmod 12,3$ i 1970.

53. Semmler/Hoffmann, Økonomisk krise, massearbejdsløshed og global-styring i KURASJE 17 , p. 60 .

54. Sml. tillige J. Brinch, Kapitalakk. II om de modgående faktorers forklaringsværdi mht. for$\emptyset$ gelsen af produktiviteten. 
ekspansion er som i 60'erne bundet til forøgelse af kapitalindsatsen med det deraf følgende fald i kapitalproduktiviteten og i sidste ende i profitraten.

\subsection{Foreløbig sammenfatning}

Vi kan af det foreløbigt skrevne konkludere, at udviklingen i kapitalforholdet frem til krisens gennemslag i 74/75 har skærpet profitvilkårene i flere henseender:

1. Den næsten ubrudte stigning i $\mathrm{K} / \mathrm{L}$ har været ensbetydende med stigende kapitalbehov, som kun kan realiseres, hvis produktiviteten stiger tilsvarende (altså minimum konstant $\mathrm{Y} / \mathrm{K}$, det har med undtagelse af 67-72 ikke været tilfældet) og/eller profittens andel af nyværdien vokser i samme grad (konstans i pi), at det ikke har været tilfældet, er fremgået. Den stigende kapitalintensitet er et andet udtryk for at den nødvendige kapitaludrustning pr. arbejdsplads stiger, eller omvendt at samme akkumulerede profit kan beskæftige færre antal arbejdstimer, mindre variable kapital og dermed tendentielt opsuge mindre merværdi. Det er yderligere fremgået at

2. Væksten i profitmassen ikke har kunnet kompensere faldet i -raten på langt sigt, hvad der har givet sig udtryk i periodisk overakkumulation i midten af 60'erne og i den nuværende krise, dermed må i forlængelse af 1) antal arbejdstimer, beskæftiget gennem akkumuleret profit, stagnere eller gå tilbage, og med andre ord forstærke den tendens til underbeskæftigelse, der initierede tilbagegangen. Den eneste udvej herfra er forøgelse af profitraten, enten gennem sænkning af arbejdskraftens værdi uden modsvarende forøgelse af kapitalindsatsen eller gennem sænkning af værdien af det kapitaludlæg profitten skal stå i forhold til.

\subsection{Lønnen}

Af kritikere af den kapitallogiske tradition og af borgerlige økonomer fremføres i god overensstemmelse med forvekslingen af merværdirate med profitrate, at den egentlige årsag til det fald i profitraten, som er konstaterbart er lønstigningerne, »ikke den stigende mekanisering (som Brinch mener), men den omstændighed, at arbejdere og funktionærer gennem lønkampen har opnået reallønstigninger, der ikke blot har fulgt produktivitetsstigningerne, men i en vis udstrækning overgår dem, har været den afgørende faktor bag den faldende profitrate i 60 'erne. $\ll^{55}$

55. Groth i Kap.akk. II, op. cit. p. 30. 
Som det fremgår af figur 5 mere end modificerer den empirisk konstaterbare udvikling denne påstand.

Figur 5. Udviklingen i kapitalproduktivitet og -rentabilitet, indeks (1964=100)

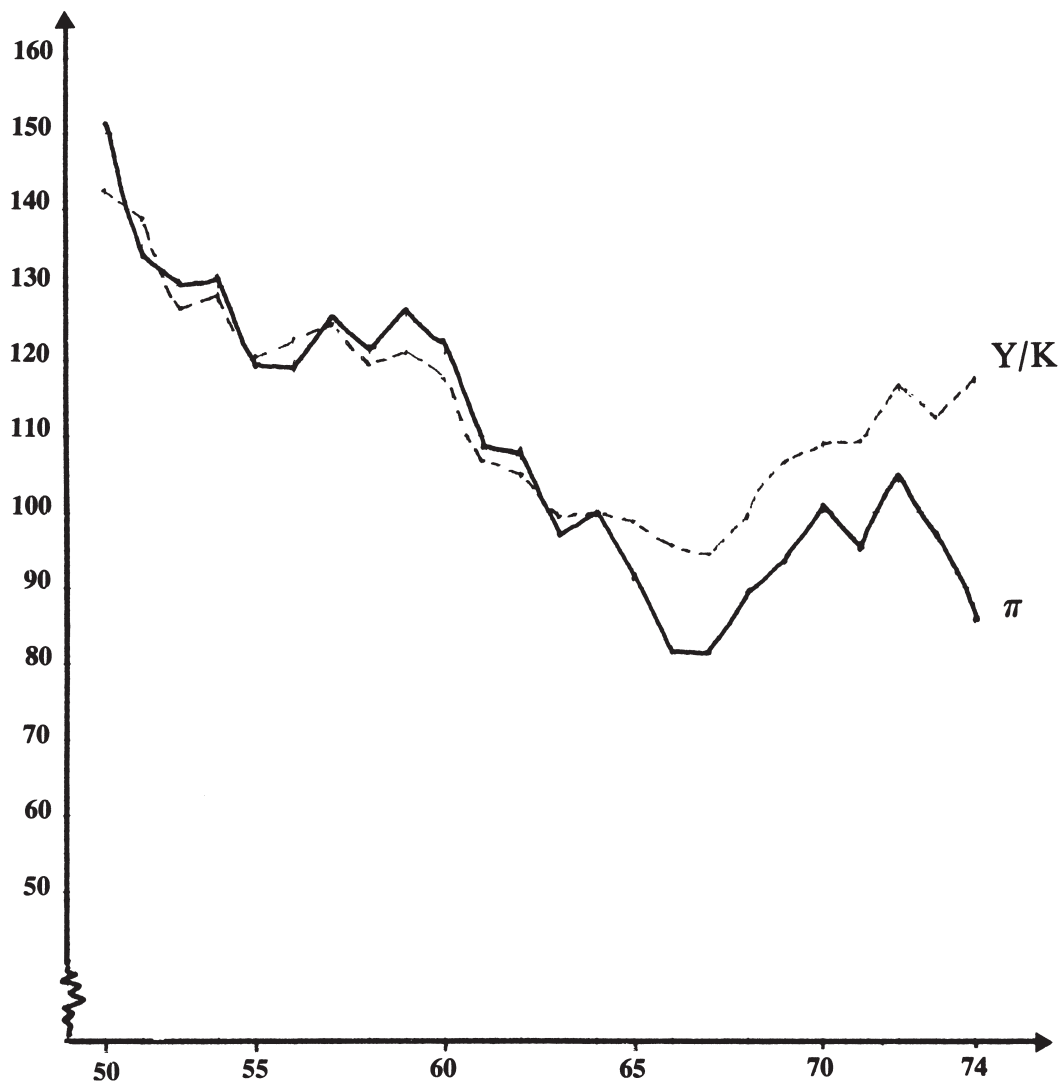

Kilde: Egne beregninger på basis af Bredsdorff m.fl. op.cit.

De mest fremherskende karakteristika ved forholdet mellem rentabilitet og kapitalproduktivitet er således, at de »følges ad« i op- og nedgange. På intet tidspunkt bevager pi sig $i$ en retning, som er modsat bevagelsen $i$ kapitalproduktiviteten. Stigninger og fald i profitabiliteten kan således uden undta- 
gelse forklares ved bevægelserne i kapitalens sammensætning, ved forholdet mellem levende og dødt arbejde. Det andet karakteristikum er, at lønudviklingen forstcerker bevægelsesretningen i kapitalproduktiviteten, men dette gælder ikke alene for nedgange heri. Også når pi stiger, stiger den kraftigere end $\mathrm{Y} / \mathrm{K}$, fordi lфnkvoten falder (gælder fra 56-59 og fra 67-70 og selv efter »minirecessionen « i 72 stiger profitkvoten, se tabel). Når det alligevel kan se ud som om lønstigningerne er krisens årsag, kan det hænge sammen med den kraftige uddybning af tilbageslagene i pi som finder sted i 67 og 74. Denne uddybning er en konsekvens af sammenfaldet af realiseringsvanskeligheder og produktivitetsstigninger i krisegennemslaget. På den ene side vanskeliggøres realiseringen af de producerede varer, i hvert fald til de hidtil gældende priser og dermed den fulde profit (evt. inflationerede), på den anden side fortsætter lønningerne at stige, dels fordi krisens disciplinerende virkninger på lønkampen endnu ikke har sat sig igennen, og dels fordi lønningerne specielt i DK er bundet til produktivitetsstigningerne. ${ }^{56}$

At stigningen i profitkvoten (faldet i lønkvoten) ikke har været tilstrækkelig i perioden 67-70 til at genetablere »parallelliteten « mellem Y/K og pi (som fremgår af indeks), at lønstagnationen altså ikke har været kraftig nok (absolut nok) kan skyldes dels recessionens mildhed, dels dens korte varighed. ${ }^{57}$ Alt tyder derimod på, at der i den nuværende krise med fald i reallønnen i både 76 og 77 og sandsynligvis i 78 vil være så stor forbedring i profitkvoten, at pi forbedres i forhold til Y/K. Men dermed er ikke sagt, at pi vil være forbedret nok, idet netop kapitalproduktiviteten har vist et voldsomt fald i hvert fald i krisens første år. Dette sidste i forlængelse af det ovenfor skrevne præciserer kun kriseproblemet til at være bundet til kapitalstrukturudviklingen og ikke til den langfristede udvikling i fordelingsforholdet mellem lønarbejde og kapital, eller til den »funktionelle fordeling $\ll^{58}$

56. Det gælder direkte for de 70\% af arbejdskraften (under DA) som er aflønnet efter bevægelige lønsystemer, men også ved de generelle overenskomstforhandlinger er der tale om binding til produktivitetsforøgelsen, men til forgående års forøgelse, idet tidligere lønglidning lægges til grund for generelle krav.

57. Og ikke mindst, at stigningen i produktiviteten har været bundet til arbejdsintensivering, som med de bevægelige lønsystemer i højere grad slår igennem i lønstigninger end produktivitetsstigninger betinget af teknologiske ændringer.

58. Som hos Per Kongshøj Madsen og Carsten Koch: Den funktionelle fordeling i Danmark i efterkrigstiden. 


\subsection{Endringer i produktionens fordeling på sektorerne}

Betragtet som reproduktionsproces må den langfristede stigning i kapitalsammensætningen, som konstateres ovenfor, betinge en modsvarende stigning $\mathrm{i}$ investeringsgodeproduktionen samt $\mathrm{i}$ de sektorer, der producerer den flydende konstante kapitals elementer. ${ }^{59}$

For så vidt denne stigning er ensbetydende med vækst i den konstante kapitaldel i forhold til den variable, det vil sige for så vidt en tilsvarende eller, som det fremgår af forskellen mellem produktivitet og realløn, en faldende del af mængden af levende arbejde går til reproduktion af arbejdskraften, må forandringerne i kapitalens struktur modsvares af forandringer i henholdsvis sektor I's (konstant kapital) og sektor II's (konsummidler) andele af produktionen, således, at sektor I vokser relativt til sektor II, mens de begge vokser absolut.

Selvom det ikke er muligt empirisk at differentiere eksakt mellem produktionsmidler og konsumtionsmidler, og derfor heller ikke mellem produktionsmiddel- og konsumtionsmiddelbrancher (hertil kommer at brancher og enkeltvirksomheder producerer flere produkter, hvoraf nogle er produktionsmidler eller halvfabrikata og nogle er konsummidler) kan man søge at illustrere udviklingen i branchernes andele ved to indikatorer:

a) andele af de ydede arbejdstimer og

b) andele af værditilvæksten.

Tabel 6. Procentvise andele af antal prasterede arbejdstimer i industrien

\begin{tabular}{|l|c|c|c|c|c|c|c|}
\hline & 50 & 59 & 65 & 65 & 68 & 71 & 74 \\
\hline sektor I & 45,0 & 51,3 & 51,8 & 50,6 & 49,1 & 50,3 & 56,2 \\
\hline sektor II & 37,2 & 29,8 & 30,0 & 30,4 & 29,8 & 28,9 & 25,4 \\
\hline
\end{tabular}

Kilde: Statistisk Tiårsoversigt div. år.

59. Som hørende til sektor I er regnet følgende brancher: råstofudvinding, kemisk industri, sten-, ler- og glasindustri, jern- og metalindustri samt transportmiddelindustri. Til sektor II er regnet: Næringsmiddelindustri m.m., tekstilindustri samt fodtøjsog beklædningsindustri. 
Ad a) Af tabel 6 fremgår, at sektor I's andel af ydede arbejdstimer er vokset kraftigt fra 45\% i 1950 til over $56 \%$ i 1974 i forhold til de øvrige industribrancher, mens konsummiddelsektorens andel er faldet tilsvarende fra ca. 37\% til ca. 25\% fra 50-74. Der er således sket en forskydning i beskæftigelsen fra sektor II til sektor I. Især den kemiske industri er vokset kraftigt i perioden, men den tilsvarende forskydning finder sted, hvis man alene betragter investeringsgodesektoren. ${ }^{60}$

Ad b) Vi betragter dernæst fordelingen af værditilvæksten i tabel 7.

Tabel 7. Procentvis andel af industriens værditilvækst

\begin{tabular}{|l|c|c|c|c|c|c|c|}
\hline & 50 & 59 & 65 & 65 & 68 & 71 & 74 \\
\hline sektor I & 45,1 & 52,8 & 53,3 & 51,0 & 51,2 & 51,4 & 57,3 \\
\hline sektor II & 38,5 & 28,4 & 26,1 & 29,7 & 28,5 & 27,9 & 26,7 \\
\hline
\end{tabular}

Kilde: Statistiske Tiårsoversigt div. år.

Sektorernes andele af værditilvæksten udviser samme tendens som under a), her stiger sektor I med ca. 15\%-point mens sektor II's andel falder tilsvarende.

Den lidt større stigning i sektor I's andel af værditilvæksten end af antal arbejdstimer skyldes, at produktivitetsstigningerne har været lidt større her (især i kemisk industri).

Denne trendmæssige stigning i produktionsmiddelsektorens andel af den samlede produktion understreger det, der er fremført tidligere om stigningen i den organiske sammensætning. Også for DK gør dette sig altså gældende. Er der ikke teoretiske, så er der i hvert fald empiriske argumenter for uomgængeligheden af stigning i organisk sammensætning og

60. Således er både jern- og metalindustriens andel af den samlede arbejdsstyrke og værditilvækst vokset, og heraf er maskinindustrien og især de dele heraf, der fremstiller industrielle maskiner vokset kraftigst (fra 33\% i 66 til 67\% i 71, se Teknologi, arbejdsorganisation og kvalifikation - og udviklingen i den danske industri efter 1950, af J. F. Lauridsen m.fl., p. 297-298. Dette forstærker således de tendenser, der er nævnt ovenfor, og også her er der tale om en vedvarende stigning gennem hele perioden. 
værdisammensætningen. Da dette ikke blot er et nationalt dansk fænomen, tværtimod er DK et af de lande de har haft størst relativ vækst i konsummiddelproduktionen, kan stigende eksport af kapitaludstyr ikke bortforklare denne stigning.

\subsection{Sammenfatning}

For udviklingen i efterkrigstiden er det karakteristisk både for DK og for en række andre kapitalistiske lande, at kapitalsammensætningen er steget, udbytningen er forøget, men ikke nok til at modvirke profitratens faldende tendens. Det afgørende træk i forhold til den nuværende krise er stigningen i kapitalsammensætningen. Dette udtrykker sig i en stigning i investeringsgodesektoren og i de sektorer, der producerer den flydende konstante kapitals elementer. Denne overudvikling i sektor I antyder således også, at den samfundsmæssige efterspørgsel i stadig højere grad er efterspørgsel efter kapital. Produktionen af kapital bestemmer efterspørgslens størrelse og natur (sammensætning). Dermed angives tillige hvorfor overekspansion af og til i sektor I bliver et problem. Det, der falder med den nuværende krise, og i det hele taget med overproduktionskriser er efterspørgslen fra og af kapital, konsumefterspørgslen abstrakt naturligvis tilsvarende, omend i mindre grad, og realt i endnu mindre omfang pga. sikringen ved arbejdsløshed. Det, der er for stort, er derimod ikke sektor I men sektor II, for stor fordi den udtrykker, at arbejdskraftens værdi er sænket mindre end nødvendigt for kapitalens fortsatte ekspansion, derfor vil opsvinget heller ikke (men måske nok krisen) indledes med en reduktion af den »for store « sektor I, men af ekspansion heri og stagnation og dermed relativ tilbagegang i sektor II. Det, der således ved krisens gennemslag kan synes en fordel for DK, den høje andel af produktionen, der består af »nødvendige subsistensmidler«, kan ved genopsvinget blive møllestenen, der sinker hastigheden her.

Endelig skal betones, at med forskydningen af produktionen til sektor I, bliver hele den samfundsmæssige $\varnothing$ konomiske stabilitet i langt højere grad afhængig af en kontinuert efterspørgsel efter produkter fra begge afdelinger. Falder efterspørgslen efter konsummidler, svinder også grundlaget for nye investeringer i produktionsudstyr i sektor II, og dermed falder efterspørgslen efter sektor I's produkter. Konsekvensen bliver yderligere indskrænkninger, mangel på efterspørgsel indenfor sektor I etc. 
Dette kan også udtrykkes anderledes:

Når den del af den samfundsmæssige produktion, der fremstiller produktionsmidler, vokser relativt i forhold til den samlede produktion, må, for at sikre realiseringen af den producerede værdi, den del af den samfundsmæssige nyværdi, der investeres i fast kapital, stige relativt i forhold til nyværdiens totale størrelse, eller med andre ord: investeringsraten skal vokse tilsvarende.

Men investeringsraten er i første række bestemt af væksten i profitmassen, der som vi har set, har været faldende. Teoretisk og empirisk vistes, at den stigning i kapitalsammensætningen, der samtidig betinger forskydningen i den samfundsmæssige produktion, modsvares af en faldende tilvækst i profitmassen.

Dermed fremstår umuligheden af en ligevægtig kontinuert kapitalistisk ekspansion. De samme faktorer, som fremkalder en faldende profitrate, stiller for den kontinuerte realisering nødvendigheden af en tiltagende akkumulation, som kun kan »indløses« så længe profittens masse vokser mere, end dens rate falder. Men som vi har set ovenfor, vokser profittens masse med en aftagende tilvækst, fordi den del af arbejdsdagen, som er ubetalt, og som tilvæksten står i forhold til, er voksende, mens den del af arbejdsdagen, hvorfra tilvæksten til merværdien »tages«, er stadigt aftagende. Processen når til et punkt, hvor denne tilvækst ikke er tilstrækkelig til at valorisere den udlagte kapital, og derfor heller ikke tilstrækkelig til at sikre at akkumulationen fortsætter, endsige udvides. Konsekvensen er, at efterspørgslen efter produkter fra sektor I stagnerer. Den manglende udvidelse af merværdien fremstår i den samfundsmæssige reproduktionsproces som realiseringsvanskeligheder for de kapitaler, der producerer produktionsmidler. ${ }^{61}$

Dermed er også klart, at den logiske konsekvens af den kapitalistiske udvikling ikke er underkonsumtion som kriseårsag, men overakkumulation. Den manglende realisering er mangelende realisering af den forvoksede produktionsmiddelsektors produkter, fordi profitten ikke laengere er voksende. ${ }^{62}$

61. Derfor er betingelserne for genopsving i den borgerlige økonomi også knyttet til forøget efterspørgsel efter produktionsmidler, som det kommer til udtryk hos bla. DØR.

62. Også for DK har denne modsætningsfyldte udvikling gjort sig gældende. Som det er fremgået tidligere har investeringsraten været faldende, mens som vist i dette afsnit, produktionsmiddelproduktionen har været stigende. Når bortses fra stigende eksport, kan udeblivelsen af en åben efterspørgselsmangel før krisegennemslaget overfor sektor I bla. forklares ved, at statens investeringer i den periode hvor investeringsraten faldt, var tiltagende (67-72), men fra 72 faldende. Udvidelsen af de statslige investeringer faldt (utilsigtet, men heldigt) så at sige i et hul i de private investeringer. 
Dette tiltagende realiseringsproblem, som fremtræder i konjunkturbevægelsen som manglende efterspørgsel, skal jeg i næste afsnit om den cykliske formidling søge at eksplicitere som udlфsende krisen, og dermed indikere at krisen er en overakkumulationskrise.

\section{Den cykliske udvikling og krisens gennemslag}

Hovedpointen med undersøgelsen af den langfristede udvikling skulle være at unders $\emptyset$ ge, om der set fra forholdet mellem den producerede værdi og de »aktive « kapitaludlæg for dansk industris vedkommende er tale om overakkumulation, om der altså i den lange prosperitetsfase har fundet sådanne ændringer sted i kapitalforholdets sammensætning, at produktionens kontinuerte udvidelse i afgørende grad var truet heraf eller blev bundet til så restriktive forudsætninger, at kun ekstraordinære foranstaltninger, herunder først og fremmest krisen, kan sikre en fortsat akkumulation.

Resultaterne af denne undersøgelse, som er sammenfattet overfor peger på:

1. at den industrielle kapitals akkumulationsbetingelser er stærkt forringede både med hensyn til profitraten og med hensyn til udviklingen i profitmassen, og

2. at stigningen i den organiske sammensætning er forbundet med en relativ vækst i sektor I's andel af produktionen og dermed med en forøget følsomhed for hele systemet overfor efterspørgslen.

Betydningen af disse langfristede udviklingstræk fremstår ikke i sig selv, men formidles af den konjunkturelle cyklus. Så længe markedet er ekspanderende, så længe alle varer realiseres, og derfor så længe nedlagt arbejde realiseres som værdiskabende, fremstår stigningen i kapitalsammensætningen og forskydningen i den samfundsmæssige produktion ikke som skranke for den fortsatte akkumulation. Først når markedet er kontraktivt, når allerede producerede varer ikke kan sælges, ophører nedlagt arbejde at være ensbetydende med værdiskabelse, kun en del af det ydede arbejde realiseres som værdi. Krisen eller skrankerne for den kapitalistiske produktion fremstår derfor først som realiseringsproblem på markedet, som manglende efterspørgsel.

I forlængelse heraf må undersøgelsen af krisegennemslaget derfor prøve, med udgangspunkt i den cykliske akkumulationsudvikling, at klarlæg- 
ge, hvorledes efterspørgslen bliver et problem i forhold til de gennemsatte ændringer i kapitalstrukturen, og på den anden side hvorledes ændringerne i denne atter determinerer efterspørgslen både efter bestemte produkter, men tillige niveauet for efterspørgslen.

Anvendeligheden og tilstrækkeligheden af trendanalysen er derfor begrænset af flere grunde; for det første fordi de strukturelle ændringer ganske vist udgør betingelserne for den $\varnothing$ konomiske reguleringspolitiks effektivitet overfor krisefænomenerne, men ikke angiver indgrebsgenstanden og dermed erfaringsgrundlaget, således som det fremstår på det borgerlige samfunds overflade. For det andet fordi den aftegnede udvikling fremstiller resultaterne af enkeltkapitalernes handlinger, men derimod ikke kan fremstille det grundlag, disse reagerer på og dermed ikke den cyklicitet, som formidler ændringerne i kapitalsammensætningen.

Den cykliske udvikling som fremstår i konjunkturbevægelserne, der med Mattick kan karakteriseres som en sammenpresning af profitratens langsigtede fald ${ }^{63}$ har som udgangspunkt industrikapitalens afkast, ${ }^{64}$ det vil sige

63. Se Marx og Keynes, p. 64. Men dette er kun en karakteristik, andet steds fastslår Mattick selv problemerne i forbindelse med forståelsen af konjunkturens op- og nedgange til at være bundet til markedets betingede bevægelser: »Således kan enhver krise kun forklares ud fra den foregående konjunktur og denne igen ud fra, at konjunkturen ikke afhang af samfundets konsumtionskraft, men af enkeltkapitalernes akkumulationsbehov - givet gennem kapitalkonkurrencen - som til enhver tid ikke vokser svarende til et givet marked, men derimod udvider sig svarende til et forventet marked «. Men problemet er at forstå markedet: »Krisen er lettere at forstå end konjunkturen,... Men det er slet ikke så indlysende, hvordan kapitalen i længere perioder kan skride fra konjunktur til højkonjunktur trods dens iboende modsigelser, når udbuddet samtidigt er svagere end efterspørgslen. Det bliver forståeligt gennem den historisk bekræftede kendsgerning, at det marked som akkumulationen skaber, ikke er andet end udviklingen af det kapitalistiske samfund selv.« og »Denne aldrig afbrudte proces (udviklingen af det kapitalistiske samfund) og dens acceleration tillader, at selv de voksende varemængder finder et marked, eftersom dette vedvarende bliver udvidet gennem akkumulationsprocessen.« Mattick, Kriser og kriseteorier, p. 58 og 59.

64. Forskellen mellem dette profitabilitetsmål og kapitalrentabiliteten i foregående afsnit, hvor afkastet eller afkastningsgraden udtrykker nettoprofitten mens kapitalrentabiliteten angiver den værdisættende evne, kapitalens produktivitet, er betinget af en række udenfor det umiddelbare kapitalforhold stående faktorer (eks. skatter, rentebelastninger, prisfluktuationer) som reducerer eller forøger nettoprofitten. For korttidssvingninger er der således ikke noget umiddelbart parallellitetsforhold mellem disse profitrelationer. På langt sigt derimod er de forhold, der er bestemmende for kapitalrentabiliteten tillige regulerende for bevægelsesretningen i afkastningsgraden.

Når afkastningsgraden derfor tages som udgangspunkt for konjunkturanalysen, er det dels fordi den alene udtrykker konjunkturfænomenernes indvirkning på profitforholdene, dels fordi den dermed er den forrentning enkeltkapitalerne kan se og måle, og som de reagerer i forhold til. 
forholdet mellem realiseret profit og udlagt kapital, som det fremstår på samfundets overflade. Profitraten som konjunkturcyklens drivkraft, ${ }^{65} \mathrm{dvs}$. kapitalernes reaktioner med udgangspunkt i den realiserede profitrate og dens forventede udvikling i profitabiliteten danner således udgangspunkt for fremstillingen af, hvorledes mangel på merværdi fremstår som overproduktion af varer, hvorledes overakkumulationskrise fremtræder som overproduktionskrise, og dermed med andre ord for at fremstille sammenhængen mellem den langfristede udvikling i kapitalforholdet og den cykliske akkumulation og dermed den nuværende krises fremtrædelsesform.

Hertil er det vigtigt, som Semmler og Hoffmann fastslår, at betragte kapitalen i dens dobbelte eksistensform som kapitalvardi og som produktiv kapital i stoflig form. Som kapital i pengeform, som udlagt pengekapital, der skal valoriseres i forhold til en vis profitrate, og - især med henblik på den cykliske udvikling - som kapital i stoflig form som »akkumuleret produktionspotens «, »hvis anvendelse og udnyttelse afhænger af den kontinuerte realisering af den producerede varekapital, kort: af eftersp $\phi$ rgslen. $\ll^{66}$ Herved bliver udnyttelsen af den akkumulerede produktionskapacitet, og dermed efterspørgslen, som regulerer anvendelsen heraf på kort sigt, i denne henseende bestemmende for profitraten, mens omvendt profitraten er bestemmende for udviklingen i efterspørgslen, og dermed for udnyttelsesgraden af den eksisterende produktionskapacitet.

Set i denne sammenhæng bliver derfor den eksisterende profitrate forudsætningen for udviklingen i den kommende profitrate: eller den forventede profitrate bliver i den udstrækning den har baggrund i den eksisterende profitrate og afspejler ændringerne heri, til den virkelige profitrate via reguleringen af efterspørgslen. I den forstand afspejler den borgerlige $\emptyset$ konomis konjunkturforståelse realiteten i markedet som forudsætning for profitabiliteten. ${ }^{67} \mathrm{På}$ den anden side hviler denne forståelse på en række forudsætninger, som afgørende sætter dens realitetsnærhed ud af kraft. Den baserer sin opfattelse på enkeltkapitalernes forventninger, på disses forestillinger om den fremtidige markedssituation, profitrate etc., og kun i den udstrækning de handlinger, disse forventninger afføder, har konsekvenser

65. Sml. Semmler/Hoffmann, op. cit. p. 65.

66. Semmler/Hoffmann, op. cit. p. 65.

67. Men dette gælder naturligvis kun i den udstrækning profitraten er bestemt af udnyttelsen af den eksisterende kapacitet. Her afspejles derimod ikke sænkningen af profitraten af de strukturelle grunde, deraf dobbeltheden. 
for den samlede $\varnothing$ konomi ${ }^{68}$ som modsvarer forventningerne hos enkeltkapitalerne, som realiserer disse forestillinger, kun i den udstrækning udgør kapitalagenternes selvforståelse et adækvat udgangspunkt for beskrivelse af konjunkturudviklingen. Men som det kendes fra fremstillingen af gennemsnitsprofitraten, er det netop karakteristisk, at udviklingen i de samfundsmæssige relationer sætter sig igennem »bag ryggen« på kapitalagenterne og fremstår på samfundets overflade som uforklarede forudsatninger for disses ageren. ${ }^{69}$

På denne baggrund kan det være vigtigt at slå fast, at den borgerlige $\varnothing$ konomiforståelse ganske vist på den ene side danner udgangspunkt for enkeltkapitalernes handlinger, men at den på den anden side ikke kan medreflektere de samfundsmæssige konsekvenser heraf. Med henblik på analysen her: at markedfænomenerne danner udgangspunkt for produktionens agenters (og det vil tillige sige statens) handlinger, og derfor skal indgå som forklarende her, mens konsekvenserne i de fleste tilfælde ligger udenfor markeds $\varnothing$ konomiens horisont, og derfor fremstår som uforudsete følgevirkninger som - i tilfældet staten - kræver nye korrektive indgreb.

Der fremstår heraf tre forhold, som må indgå i undersøgelsen af den seneste cyklus og forklaringen på krisens form:

1. Forrentningen af den udlagte kapital og udviklingen i de komponenter, der kan forklare bevægelserne heri (som tidl. kapitalintensitet, arbejdsproduktivitet og lønnen, men tillige en række andre faktorer).

2. Ophobningen af produktiv kapital i stoflig form, hvis udnyttelse er betinget af efterspørgslen, og som atter betinger denne.

3. Udviklingen i efterspørgslen, som er betinget af profitabiliteten og afsætningsmulighederne på verdensmarkedet.

\subsection{Forudsætninger for konjunkturens forløb}

Den langfristede udvikling i den danske industri har haft afgørende betydning for den cykliske bevægelsesform i mindst to henseender:

68. Men sådanne konsekvenser forbliver mest tilfældigheder. Et karakteristisk træk ved markedet er netop dets uigennemskuelighed, som for enkeltkapitaler er større jo mindre deres markedsandel er, jo stærkere konkurrencen er. Derfor øges uigennemskueligheden i krisen, og optræder for enkeltkapitaler som årsagen til deres vanskeligheder, mens det i realiteten forholder sig omvendt.

69. Sml. kritikken af Madsen/Vangskjær tidligere. 
1. Med dannelse af en egentlig industrikapital (den »anden industrialisering «) fra slutningen af 50'erne, som blev det dominerende element i den samlede $\varnothing$ konomi, udvikler der sig tillige en egentlig selvstændig industriel cyklus. Fra recessionen i 63 (som var internationalt udbredt) fremtræder parallelle konjunkturudsving. ${ }^{70}$ Fra den samtidige krise i 67 udvikles en egen industriel cyklus med samme forløb og næsten samme varighed, som i resten af den kapitalistiske verden, og som jo længere jo mere falder sammen med udviklingen i den vesttyske kapital.

2. Med den danske akkumulationsudviklings karakter som »afhængig« og med stigende integration i verdenshandelen via voksende import- og eksportkvoter, bliver tilsvarende den cykliske akkumulationsbevægelse og krisens gennemslag bestemt i stadig højere grad af forholdene på verdensmarkedet. Dette er baggrunden for den synkronisering af konjunkturerne - og for DK's vedkommende den binding af den »nationale konjunktur« til de vigtigste konjunkturbærende eksport/importmarkeder ${ }^{71}$ som for alle nationalstater hindrer at krisen kan eksporteres, og som i langt mere udpræget grad for de små nationalkapitaler, svækker styringseffekterne og mulighederne ved statslige interventioner, og bidrager dermed til, at krisen slår igennem med fuld styrke, som gennemsættelse af den verdensmarkedsbestemte gennemsnitligt nødvendige arbejdstid. ${ }^{72}$

For krisecyklen fra 67/68 til 74/75 er ligheden i forløbet udpræget. ${ }^{73}$ I denne periode udvikler krisecyklen i BRD sig som en 7-8 årig cyklus med en mellemkrise. Fra krisen i 66/67 over opsving i 68-69-70, mellemkrise i 71-72 og boom i 73 til krise i 74/75. For Danmark er udviklingen stort set den samme, dog forskudt en smule især i begyndelsen. Fra BRD importeres krisen, som bliver virksom i 67/68. Herefter følger opsving i 69 , kontraktion i 70 , tilbageslag i $71 / 72$, boom i $72 / 73$ og krise i slutningen af $74 \mathrm{og}$ ind i 75. Cyklens længde er som den tyske ca. 7 år

70. Indtil 1963 udviser den danske $\varnothing$ konomi stort set ikke de karakteristiske konjunktursvingninger som kendes fra de $\emptyset$ vrige kapitalistiske $\varnothing$ konomier. Tydeligt kommer dette frem i den stabile tendens i investeringskvoten (eks. fraværet af svingninger som følge af den internationale recession i 1958.

71. Som i stadig højere grad bliver BRD direkte i kraft af stigende samhandel, indirekte i kraft af BRD's voksende betydning som konjunkturbærende.

72. Den hidtidige udvikling på verdensmarkedet kan vanskeligt forståes som andet end en udligningsproces, der har sat sig relativt gnidningsløst igennem indtil videre.

73. Følgende er efter Bredsdorff m.fl. op. cit. 
og forløbet det samme: krise, opgang, tilbageslag, boom og krise. ${ }^{74}$ Denne udvikling understreger således det, der er skrevet ovenfor. På den ene side er den danske udvikling bestemt eksternt af de konjunkturbærende nationalkapitaler, men på den anden side udelukker ensartetheden ikke, at der også er interne grunde til forløbet, at den danske industri har gennemløbet en akkumulationsudvikling, der stort set svarer til den tyske, og at denne udvikling selvstændigt har betinget krisen i DK, dette sidste skal selvfølgelig ikke tages for absolut, under alle omstændigheder er sammenfaldet i udviklingen afgørende, dels fordi akkumulationens forløb også er bestemt eksternt, og dels fordi selv med den givne danske udvikling ville resultatet (krisen) sandsynligvis ikke have været det samme uden den sammenfaldende udvikling.

Hvor produktion og realisering er adskilte fænomener, men dog således at produktionen bestemmer realiseringen, mens omvendt realiseringen er forudsætningen for produktionens kontinuitet, bliver verdensmarkedet som realiseringspotentiale en uafhaengig forudsætning for den danske industriudvikling. Krisen i 67/68 gør afhængigheden tydelig. Tysklands »eksportering « af krisen modsvares af bla. Danmarks »importering « heraf. Men samtidig havde, som det fremgår af forrige afsnit, den danske akkumulation vist symptomer på stagnation, som med tilbageslaget internationalt i produktion og skærpede realiseringsbetingelser på verdensmarkedet, og dermed manglende muligheder for at eksportere sig ud af stagnationen betød, at krisen slog igennem som faldende vækst (industriens BFI voksede i faste priser kun med under 6\% i 66 og $67 \bmod$ mere end 18\% i de to foregående år) og stigende arbejdsløshed (3,2\% i 67 og 5,2\% i 68) i slutningen af 67 og i 68.

Krisens funktion i den kapitalistiske udvikling fornægtede sig ikke. Som renselseskrise var den med hensyn til en række forhold effektiv. Produktiviteten steg mere end nogensinde før, mere end $20 \%$ i de to år 67 og 68, og vel at mærke en stigning, som ikke alene er et »statistisk fænomen «, dvs. ikke alene er et udtryk for at de mindst produktive arbejdere er fyrede, eller at de lavest produktive kapitaler er udrenset, i så fald skulle stigningen have været kortvarig. Tværtimod steg også produktiviteten de følgende år, var altså dels en varig forbedring og dels en

74. En sammenligning af investeringsforløbet ville understrege ligheden yderligere. Her ville det vise sig at »investeringskurverne « for BRD og DK er stort set ens, med ca. 1/2 års forskydning. 
forbedring, som fortsatte ud over selve kriseårene. Sammenholdt med de lave investeringer kan dette ikke betyde andet, end at de investeringer, der fandt sted, var udprægede rationaliseringsinvesteringer, og at indførelsen af nye arbejdsprocesorganiseringer, gennemsættelsen eller udbygningen af modsvarende produktivitetsfremmende lønsystemer etc. forøgede arbejdsintensiteten i voldsom grad. Hvad angår lønudviklingen faldt stigningstakterne for lønnen, mens inflationen på det nærmeste skærpedes med resultat, at reallønstigningerne ${ }^{75}$ blev små og profitkvoten steg. Når dette sammenholdes med den udrensning af kapitaler, der fandt sted, ${ }^{76}$ kan sammenfattende konkluderes, at krisen resulterede i en forbedring af profitabiliteten (udtrykt i rentabilitetsmålet), der muliggjorde, at opsvinget på verdensmarkedet kunne følges af opsving i den danske industriproduktion.

Men i denne sammenhæng er det vigtigt at præcisere, at profitabilitets- eller rettere rentabilitetsforbedringen væsentligst skyldes to faktorer, nemlig en økonomisering med den faste konstante kapital, som for en dels vedkommende er et engangsfænomen (eks. nedlæggelse af forældede produktionsanlæg i krisen, men derimod ikke udprægede koncentrationstendenser, hverken

75. Stigningen i $\%$ i nominal og realløn.

\begin{tabular}{|l|c|c|c|}
\hline & 66 & 67 & 68 \\
\hline nominalløn & 12,2 & 8,7 & 11,7 \\
\hline inflation & 7,6 & 7,0 & 8,2 \\
\hline realløn & 4,3 & 2,3 & 3,3 \\
\hline
\end{tabular}

76. Således faldt antallet af virksomheder i industrien kraftigere end ellers i 1967.

Antal virksomheder i industrien:

\begin{tabular}{|c|c|c|c|c|c|c|c|}
\hline 63 & 64 & 65 & 65 & 66 & 67 & 68 & 69 \\
\hline 6735 & 6800 & 6805 & 6304 & 6264 & 5872 & 6089 & 6033 \\
\hline
\end{tabular}

\begin{tabular}{|c|c|c|c|c|c|c|}
\hline 70 & 70 & 71 & 71 & 72 & 73 & 74 \\
\hline 5936 & 6921 & 6805 & 6807 & 6870 & 6705 & 6712 \\
\hline
\end{tabular}

Kilde: Statistisk Tiårsoversigt div. år. 
i krisen eller efter ${ }^{77}$ heller ikke en forøgelse af den gennemsnitlige ugentlige arbejdstid, der kunne forkorte kapitalens omslagstid) og en forøgelse af arbejdsproduktiviteten, som er betinget af intensivering af arbejdet, men hvis mulighedsbetingelse er produktivkraftsudviklingen i 60'ernes begyndelse, og derfor rejser problemet om dens varighed uden en tilsvarende for $\varnothing$ gelse af kapitalintensiteten. Endelig er grænserne for arbejdsintensiveringen ikke $\emptyset$ konomisk bestemte, men subjektivt satte, bestemt af arbejderklassens politiske accept af fortsatte tempoforøgelser, nedslidning, etc.

\subsection{Udviklingen i profitabiliteten}

Det bemærkelsesværdige ved den cykliske udvikling efter 67/68 er ikke stigningen i profitraten, eller at den er betinget af stigninger i arbejdsproduktiviteten, der er større end stigningerne i kapitalintensiteten. Det samme forhold mellem disse relationer gør sig gældende i BRD i de første år efter krisen. ${ }^{78}$ Det særlige ved udviklingen i profitabiliteten i DK er derimod storrelsen af produktivitetsstigninger og deres varighed. Uden modsvarende stigninger i kapitalindsatsen stiger produktiviteten med 53\% fra 6772 , og denne stigning er ikke alene absolut stor, men tillige større end de fleste $\varnothing$ vrige vesteuropæiske lande. ${ }^{79}$ Stigningen i arbejdsproduktiviteten har også givet sig udslag i en vækst i kapitalproduktiviteten frem til 72 (når undtages 71 , se senere) og i rentabiliteten. Betragter man den realiserede nettoprofitrate for industrien i forhold til det samlede kapitalforbrug, som afspejler ikke alene produktionsvilkårene, men også realiseringsbetingelserne, har den »gratis « produktivitetsforøgelse også slået igennem her som en forbedring (for enkeltkapitalerne) i afkastningsgrad, etc. ${ }^{80}$

77. Den lave koncentrationsgrad i den danske industri betegnes ofte som en fordel i krisesituationer, hvor små og mellemstore kapitaler synes at klare sig bedre end store kapitaler. Små kapitalers større fleksibilitet, mindre afhængighed af masseproduktion og en veluddannet (og velskolet?) arbejdskraft fremføres som forklaringer herpå. Men dette er dog en sandhed med modifikationer. Små og mellemstore virksomheder er også karakteriseret ved afhængighed af ét eller nogle få produkter, af større sårbarhed i kraft af deres størrelse, af manglende innovationskraft etc. En del af forklaringen på de små og mellemstores voksende andel af den samlede produktion og arbejdsstyrke i recessioner må nok så meget søges i, at tilgangen af små virksomheder overstiger nedgangen, at der altså finder en lang række konkurser sted, men at den ledige plads fyldes op af en nystartet kapital, eller selvfølgelig af store kapitaler, der bliver små.

78. Sml. Altvater, m.fl. Udviklingstendenser ... II, $i$ Kurasje 13 p. 35.

79. I det hele taget større end i de $\varnothing$ vrige OECD-lande, undtagen Japan.

80. Se hertil beregninger foretaget af Finansieringsinstituttet for Industri og Håndværk, gengivet i Dansk Økonomi, nov. 76. 
Den stagnation og tilbagegang i kapitalproduktiviteten, som indtræder i 70/71 må derfor, nærmere end at betragtes som årsag til kontraktionen på markedet, ses som effekt heraf, stigningen i kapitalintensiteten er mere betinget af tilbagegang $\mathrm{i}$ antal arbejdstimer end af forøgelse af kapitalstokken, den er altså mere udtryk for en momentan konjunkturel overkapacitet i forhold til en begrænset betalingsdygtig efterspørgsel, end for en cyklisk udviklet overakkumulering af produktiv kapacitet eller for en egentlig stigning i forbruget af fast kapital pr. arbejder (arbejdstime). Recessionen på verdensmarkedet og dæmpningen af det indenlandske forbrug i forlængelse af det store underskud på betalingsbalancen i 69 førte til overkapacitet. Sammen med større lønstigninger ${ }^{81}$ end i de foregående år, som var delvist betinget af arbejdsintensiveringens gennemslag i lønforhøjelser førte dette til fald i profitraten. Gennemførelsen af lønforbedringer var på sin side muliggjort af, dels at den stigende beskæftigelse styrkede arbejderklassen generelt og ved lokale lønfastsættelser, og dels at modstanden mod intensiveringspresset skærpedes (med større lønkompensationer til følge).

Mellemkrisen her understreger således kun, hvad der er skrevet ovenfor om den danske akkumulations afhængighed. Set fra produktionsforholdene er der intet der peger på tilbageslag, dette er alene betinget af markedsforhold, som ikke er reguleret hverken direkte eller indirekte af den danske industri, og hvor profitraten nærmere er en refleks af markedsforholdene end omvendt. Forudsætningen for den danske akkumulation er derfor som tidligere et ekspanderende marked, og vel at mærke et ekspanderende marked, hvor efterspørgselsudviklingen er bestemt eksternt i forhold til den danske industri. Dette indtryk forstærkes af udviklingen det følgende år.

Også her (slutn. af 72) var opsvinget på verdensmarkedet den direkte årsag til stigningen i produktionen. Forbedringen af kapacitetsudnyttelsen, mindre lønstigninger og fortsat stor produktivitetsstigning i 72 betød stigning i profitraten. Men fra da af var den »gratis « stigning i produktiviteten »opbrugt«, kapitalproduktiviteten faldt, investeringerne måtte forøges. Hertil kommer, at råvarepriserne steg voldsomt fra 73 , at priserne på kapitaludstyr (og dermed genanskaffelsespriserne) steg kraftigere end priserne på slutprodukter, hvad der ikke tidligere havde været tilfældet. Også i 74 hvor realinvesteringerne faldt, modsvaredes dette af stigninger i »capitalspending $« \mathrm{i}$ løbende priser, ${ }^{82}$ som ovenik $\varnothing$ bet oversteg stigningen i nominel

81. $15 \%$ i 1971.

82. Se OECD, Economic Survey, 1975, Denmark, p. 8. 
ikke-lønindkomst (profitten). Når også tilvæksten af ophobede lagervarer (især i 74) dels trykker profitten og dels forhøjer kapitaludlægget, hvorpå afkastningsgraden skal beregnes, er det ensbetydende med et fald i profitraten, et fald som satter ind allerede $i 73$, altså $i$ den tidlige fase af boom'et, og som forstcerkes af nedgangen i 74 og $75 .{ }^{83}$ Store lønstigninger i disse år bidrog ikke til at lette presset på profitten.

Med hensyn til profitraten er krisegennemslaget tillige karakteriseret ved, at en i boom'et voksende »opsparings/investerings-deficit « ${ }^{84}$ sammen med stigende realiseringsvanskeligheder, lagerophobninger, stagnerende markedsforventninger og dermed uudnyttet og urealiseret kapacitet forøger efterspørgslen efter kredit. Renten, som har været støt stigende siden begyndelsen af 60'erne »eksploderer ${ }^{85}$ i boomets slutfase (mere end fordobles fra begyndelsen af 73 til midten af 74). Det samlede resultat er at faldet $\mathrm{i}$ bruttoprofitraten accelereres af stigende rentebelastninger til en voldsomt faldende nettoprofitrate. Da mange renteudgifter i mange tilfælde er faste omkostninger betyder fald i bruttoprofitraten under et vist niveau pga. indskrænkninger i produktionen, at forrentningen af egenkapitalen eller driftsherregevinsten falder til et minimum eller forsvinder helt. ${ }^{86}$

Finansieringsinstituttet for Industri og Håndværk har foretaget nogle meget instruktive beregninger, som indikerer at denne tendens har gjort sig gældende under den nuværende krise, se tabel 8.

Krisen er på denne måde en kumulativ nedgang, hvor faldet i profitten hos enkeltkapitalerne fremtvinger reaktioner, der nok udskyder fallitten, men yderligere presser profitten ned. Resultatet viser sig statistisk som en nærmest o-forrentning af egenkapitalen, og det er ikke svært at forestille sig at dette modsvares af negativ forrentning for en stor del kapitaler, eller sagt med andre ord modsvares af en nedskrivning af den udlagte kapital, af forbrug af kapital eller destruktion af kapitalværdi i den industrielle sfære. For enkeltkapitalen betyder det forøget afhængighed af kredit til finansiering af underskud, indskrænkninger i driften (hvis ikke lukning af virksomheden) nedlæggelse af uprofitable produktionsanlæg, dermed absolut destruktion af kapital i stoflig form og som værdi, med

83. Se Dansk Økonomi, nov. 1976, p. 86-87.

84. OECD op. cit. p. 21.

85. OECD op. cit., samt Dansk Økonomi, nov. 76, p. 86.

86. Se eks. Finansieringsinstituttets beregninger over egenkapitalforrentning i D.Ø., op. cit. p. 87. 
Tabel 8. Variationer i afkastningsgrad

\begin{tabular}{|c|c|c|c|c|c|c|}
\hline \multirow{2}{*}{$\begin{array}{l}\text { Afkastningsgrad } \\
1975\end{array}$} & \multirow{2}{*}{\multicolumn{2}{|c|}{ Virksomheder }} & \multicolumn{2}{|c|}{ Omsætning } & \multicolumn{2}{|c|}{ Gnm. afk.grad } \\
\hline & & & mill. $\mathrm{kr}$ & pct. & 1974 & 1975 \\
\hline under 0 & 103 & 17 & 2.486 & 16 & 7,4 & $-3,2$ \\
\hline $0-5$ & 137 & 22 & 3.586 & 24 & 7,9 & 2,8 \\
\hline $5-10$ & 187 & 30 & 4.798 & 32 & 9,1 & 7,2 \\
\hline I alt under 10 & 427 & 69 & 10.870 & 72 & 8,3 & 3,1 \\
\hline $10-15$ & 94 & 15 & 2.378 & 16 & 11,7 & 12.1 \\
\hline $15-25$ & 71 & 12 & 1.26 & 99 & 17,8 & 19,1 \\
\hline over 25 & 24 & 4 & 506 & 3 & 22,4 & 30,4 \\
\hline I alt over 10 & 189 & 31 & 4.153 & 28 & 14,3 & 15,5 \\
\hline Total & 616 & 100 & 15.023 & 100 & 9,6 & 6,0 \\
\hline
\end{tabular}

Kilde: Finansieringsinstituttet for Industri og Håndværk A/S, Beretning til repræsentantskabet 1976, her efter Dansk Økonomi november 1976.

det for enkeltkapitalisten forhåbentlige resultat, at rationaliseringseffekten er stor nok til at virksomheden kan frembringe det overskud, der skal dække tilbagebetalingen og forrentningen af kreditten og samtidig sikre kapital til fornyet ekspansion.

\subsection{Ophobningen af kapital}

Betragtes nu akkumuleringen af produktiv kapital peger udviklingen her på konsekvenserne af valoriseringstvangen i forhold til den eksisterende produktive kapàcitet.

Opsvinget efter krisen i 67/68 havde konsekvenser for opbygningen af kapitalapparatet. I første omgang betød opsvinget bedre kapacitetsudnyttelse og stigende profitrate, og stigende marginal profitrate (dvs. stigende profit på tillægsinvesteringer). Med udnyttelsen af den overkapacitet, som var ophobet i løbet af 60'ernes første halvdel, førte derfor opsvinget også med sig stigende investeringer, der om ikke udvidede, så dog fastholdt den 
produktive kapitals ekstensivitet ${ }^{87}$ og samtidigt på grund af det store rationaliseringsindhold (sml. stigningen i Y/L) betød en kraftig udvidelse af den produktive kapacitet.

Men med de faldende stigningstakter i arbejdsproduktiviteten og indskrænkelsen af beskæftigelsen, var betingelserne for forøgelse eller blot fastholdelse af profitmassen for enkeltkapitalerne i stadig højere grad bundet til rationalisering og udbygning af det eksisterende kapitalapparat, det vil sige til forøgede investeringer i maskineri, automatiseringsudstyr o.lign. Betingelserne herfor var, som efter 67/68 sikret med det fornyede verdensmarkedsopsving i slutningen af 72. Miniboom'et fra 72-74 var derfor for dansk industris vedkommende karakteriseret ved kraftige stigninger i investeringerne, som, selvom en del nok må ses som erstatningsinvesteringer (sml. de lave investeringer fra 65-67), modsvaredes af en tilsvarende udvidelse af produktionsmulighederne.

I sammenhæng med den strukturelle skærpelse af valoriseringsbetingelserne (se forrige afsnit) udvikler boomfasen således ændringer i kapitalsammensætningen, der fremstiller overakkumulationen absolut i krisegennemslaget:

1. Profitraten falder fra 73 og det samme galder profitmassen, forstået som realiseret profit, underkastet prissvingninger og inflation (restindkomsten steg fra 73-74 kun ca. 4\% eller langt mindre end prisstigningerne samme år $\left.{ }^{88}\right)$. De strukturelle vanskeligheder træder nu frem på overfladen som absolut overakkumulation, profitraten falder og massen stagnerer (falder), udvidelsen af produktionskapaciteten i denne fase, forøgelsen af det produktive kapitaludlæg indebærer ikke nogen modsvarende forøgelse af den realiserede merværdi. Det er en udvikling, der finder sted allerede i begyndelsen af boom'et, intet vil derfor være mere forkert, end at forklare krisen ved faldende profitter på grund af realiseringsvanskeligheder, på grund af manglende efterspørgsel, tværtimod. Ikke alene stiger lønningerne og med dem massernes købekraft kraftigt i denne fase, det samme gælder eksporten (efterspørgslen på danske markeder stiger 12\% og dansk eksport stiger $6,5 \%$, hvoraf industrien tegner sig for en større stigning), som formidler det kreditfinansierede verdensmarkedsboom til den nationale industri. Langt snarere udtrykker de stigende investeringer i 73 og 74, at krisens første

87. Idet BFI steg kraftigt, mens beskæftigelsen (antal arbejdstimer) stagnerede.

88. Dansk Økonomi, op. cit. p. 86. 
symptomer allerede gør sig gældende, profitraten er faldende, konkurrencen skærpes, jagten på ekstraprofitter og fastholdelsen af profitter, som for enkeltkapitalerne skal kompensere faldet i profitraten, er langt mere bundet til konkurrence på profitable investeringer. Manglen på kapital, som udtrykker sig i stigende efterspørgsel efter kredit, er ikke mangel på produktiv kapital, men mangel på kapitaliserbar profit til rationalisering og udvidelse. Der er først og fremmest mangel på realiseret profit, fordi profittens masse for nogle kapitaler allerede er faldet, for andre stagneret. Den »hektiske investeringsaktivitet « $i$ boom'et er derfor allerede selv udtryk for, at krisen er på vej og kun holdes stangen via en skærpelse af konkurrencen, der forøger efterspørgslen midlertidigt for dernæst at fordybe krisen. Det sidste hænger sammen med at investeringsboom'et ikke alene er forøgelse af valoriseringsgrundlaget, men tillige ophobning af produktiv kapacitet, hvis udnyttelse afhænger af efterspørgslen, og som afgørende sætter betingelserne for genopsvinget og dermed for krisens renselsesvirkning.

2. Den langfristede tendens til overproportional vækst i sektor I, som fremgår af forrige afsnit, var også virksom i den seneste cyklus. Den stigende efterspørgsel efter produkter fra sektor I kommer til udtryk i produktionsindekset, se tabel 9.

Tabel 9. Produktionsindeks for industrien, udvalgte brancher

\begin{tabular}{|l|c|c|c|c|c|c|c|c|c|}
\hline & 68 & 69 & 70 & 71 & 71 & 72 & 73 & 74 & 75 \\
\hline Nærings- og nyd.midd. & 100 & 108 & 112 & 118 & 100 & 103 & 108 & 109 & 110 \\
\hline Kemisk industri & 100 & 117 & 114 & 113 & 100 & 111 & 119 & 118 & 110 \\
\hline Jern- og metalindustri & 100 & 115 & 114 & 121 & 100 & 112 & 114 & 118 & 108 \\
\hline Hele industrien & 100 & 112 & 114 & 118 & 100 & 108 & 112 & 108 & 102 \\
\hline
\end{tabular}

Kilde: Statistisk Tiårsoversigt 1976.

Væksten i sektor I's andel af produktionen, som illustreres af tabel 9, var betinget af en efterspørgsel efter produktionsmidler også fra sektor II, hvis investeringer i begyndelsen af genopsvinget endog voksede kraftigere end gennemsnittet, der foregik altså her en udvidelse af produktionspotenserne, der var kraftigere end det fremgår af væksten for de samlede investeringer. For de sidste år af højkonjunkturen modsvaredes den overproportionale 
vækst i produktionen i sektor I af en overproportional vækst i investeringerne heri, investeringerne steg kraftigere end gennemsnit i 73 og 74 og faldt mere end gennemsnittet i 75 . For begge afdelinger af den samfundsmæssige produktion var der således tale om en opbygning af produktionskapacitet, som forstærkes af anvendelsen af nye produktionsmetoder og intensiveringen af arbejdet, der begge kommer til udtryk i stigninger i arbejdsproduktiviteten.

Det væsentlige heri er, at anvendelsen og udnyttelsen $\mathrm{af}^{89}$ det udvidede produktionsapparat afhænger af den kontinuerte udvidelse af efterspørgslen. Kun så længe en tilstrækkelig efterspørgsel er til stede, og kun så længe realiseringsbetingelserne endnu er gode, kan denne udvidelse af produktionsbetingelserne udnyttes, og væksten i profitmassen for enkeltkapitalerne kompensere faldet i den samfundsmæssige profitrate. Dermed afhænger profitraten af realiseringsbetingelserne og den dermed forbundne udnyttelse af produktionspotenserne, af anvendelsen af den produktive kapital.

Men dette var som tidligere nævnt ikke tilfældet (i hvert fald ikke i DK) $\mathrm{i}$ det seneste boom. Investeringerne var stigende, men udvidelsen af produktionen stagnerede for senere (i 74) at falde. Dermed faldt for det første udnyttelsen af den produktive kapital. For det andet betød det som nævnt en skærpelse af valoriseringsvanskelighederne, profitmassen faldt og profitraten faldt endnu hurtigere. Med stigende uudnyttet kapacitet, faldende profitrate, og uden udsigt til forbedring af realiseringsbetingelserne, forsvinder grundlaget for nye investeringer og dermed efterspørgslen efter produkter fra sektor I.

Udgangspunktet for krisen var således den faldende profitrate og -masse, den manglende valorisering af den eksisterende kapital trader frem som den egentlige skranke for den kapitalistiske produktion. Kapitalen selv, mangel på merværdi i forhold til den udlagte kapital, er krisens årsag. Det kommer tydeligt frem i krisens gennemslag: manglen på profit udtrykker sig som mangel på efterspørgsel efter sektor I's produkter. Fra slutningen af 74 går industriens omsætning tilbage, og denne tilbagegang finder mest markant sted inden for kategorierne »anden investeringsvareindustri« (dvs. uden værfter) og »råstofindustri« (incl. halvfabrikata). Hjemmemarkedets forsyning med maskiner og udstyr falder ${ }^{90}$ fra 1 . halvår $1974=120$ til 2 . halvår=02 og videre

89. Se Semmler/Hoffmann, op. cit. p. 66f, samt slutningen af forrige afsnit.

90. Økonomisk Oversigt, dec. 76, bilagstabel 8. 
til 99 og 97 i hhv. første og andet halvår 75. De tilsvarende tal for importen af investeringsvarer er for 74, $130 \mathrm{og} 115 \mathrm{og}$ for 75, $109 \mathrm{og} 102$, altså under alle omstændigheder en kraftig tilbagegang fra begyndelsen af 74 .

\subsection{Overakkumulationskrise}

Krisen er som overakkumulationskrise karakteriseret ved overakkumulation af kapitalvardi, der udtrykker sig i overakkumulation af kapital i stoflig form i begge afdelinger af den samfundsmæssige produktion. For stor kapacitet i forhold til den betalingsdygtige efterspørgsel betyder manglende udnyttelse af den produktive kapital og dermed fra denne side forstærkning af profitratens fald. Overakkumulation af kapitalværdi betyder for lille merværdi i forhold til kapitaludlægget, for lav profitabilitet og fra denne side manglende efterspørgsel efter produkter som kapital. Problemets kerne er således mangel på mervardi, der fremstår som overproduktion, som overproduktion af varer og som overophobning af produktiv kapital i forhold til den begrænsede efterspørgsel.

Den strukturelle udvikling i kapitalforholdet, stigningen i kapitalsammensætningen, der som tidligere nævnt indebærer, at den samfundsmæssige produktion forskydes fra sektor II til sektor I, og svarende hertil, at den samfundsmæssige efterspørgsel alt mere bliver efterspørgsel efter produkter som kapital, danner således grundlaget for uddybningen af det cykliske gennemslag og krisens gennembrud. På den ene side betyder den lange prosperitetsfase uden dybtgående udrensninger i kapitalerne, at nødvendigheden af kapitaldestruktion og værdiforringelse, i den udstrækning konkurrencen ikke har eksekveret dette, bliver mere og mere påtrængende for genfrembringelse af valoriseringsgraden. På den anden side betyder den forøgede afhængighed af den kontinuerte efterspørgsel efter kapital, at krisens gennemslag, for så vidt det er karakteriseret af overakkumulation i begge former, rammer den totale produktion hårdere, fordi den rammer en større del.

Som det fremgik af slutningen af forrige afsnit afhænger udnyttelsen af kapaciteten ikke alene af udvidelsen af efterspørgslen slet og ret, men af den kontinuerte stigning $i$ investeringsraten. Dermed fremstår betydningen af den strukturelle udvikling i forbindelse med det cykliske tilbageslag. Når krisen har baggrund i overakkumulation - som kommer til udtryk i overophobning af kapitalvaerdi og kapital i stoflig form - er det ensbetydende med, at merværdimassen ikke under de givne betingelser kan udvi- 
des, og dermed kan investeringsraten ikke forøges, men tværtimod falder investeringerne også absolut pga. overophobningen. Uddybningen af den cykliske krise kan derfor alene forklares ved de foregående ændringer i den industrielle kapitals struktur, som fremtræder heri.

\section{Krisens karakter}

Kapitalens ekspansion, den accelererende kapitalakkumulation er betingelsen for, at krisen kan afløses af en opgangskonjunktur. »Denne aldrig afbrudte proces (udviklingen af det kapitalistiske samfund) og dens acceleration tillader at selv de voksende varemængder finder et marked, eftersom dette vedvarende bliver udvidet gennem akkumulationsprocessen. ${ }^{91}$ Var udgangspunktet for krisen, at konsumtionen var for stor eller omvendt merværdien for lille i forhold til den akkumulerede kapital, for lille til at sikre fortsat akkumulation, så er betingelsen for opsvinget genfrembringelsen af det nødvendige forhold mellem merværdi og konsumtion, eller merværdi og kapitaludlæg. Det kan siges ganske kort: »Mere af det samfundsmæssige arbejde må tilfalde kapitalen, mindre arbejderne. $\ll{ }^{92}$ Den fornyede accelerering af akkumulationen finder sted gennem fornyede investeringer, som påbegyndes allerede $i$ krisen. Krisen er skærpelsen af den indbyrdes konkurrence mellem kapitalerne, opgangsfasens praktiske broderskab er afløst af en sand kamp for at vælte tabet i forbindelse med produktionsstagnation, realiseringsvanskeligheder etc. over på andre, betingelserne herfor er for enkeltkapitalisterne, at de gennem foranstaltninger i produktionssfæren sikrer en sænkning af produktionsomkostningerne gennem forøgelse af arbejdets produktivitet (ved investeringer eller $\emptyset$ get intensivering).

Som den kapitalistiske prosperitet afhænger af den stadigt accelererende akkumulation og denne af den voksende merværdimasse, så kan omsvinget fra prosperitet til krise kun betyde, at merværdimassen, profitten ikke var stor nok, at akkumulationen ikke kunne udvides, eller at det ikke kunne betale sig at udvide produktionen - profitmæssigt set.

91. Mattick, op. cit. p. 59.

92. Mattick, op. cit. p. 55. 
Stagnation i akkumulationen og dermed den for lille profit viser sig først på markedet som nedgang i den materielle akkumulering af profit, som nedgang i første omgang $i$ investeringsraten og som nedgang $i$ investeringerne absolut, og derfor som manglende efterspørgsel efter investeringsvarer. Ikke fordi konsumtionen er for lille, men fordi der ikke realiseres merværdi nok, fordi der ikke er produceret nok merværdi, stagnerer akkumuleringen af profit, markedet skrumper, der er krise. Med nyinvesteringernes ophør, med stilstand i akkumulationen kan mervardien ikke realiseres, fordi realiseringen af merværdien for totalkapitalen finder sted gennem udvidelse af kapitalen (her er naturligvis set bort fra kapitalisternes revenu og det uproduktive forbrug) i form af fast og flydende kapital. ${ }^{93}$

Men kan merværdien ikke realiseres forsvinder incitamentet for den kapitalistiske produktion, det forsvinder for totalkapitalen og gradvist i alle sfærer af produktionen. Dermed fremgår, hvorfor vægten i forbindelse med den langvarige ekspansionsfase i efterkrigstidens kapitalistiske udvikling i $\mathrm{DK}^{94}$ blev lagt på udviklingen $\mathrm{i}$ investeringernes omfang og deres modsvar i den sektor I-produktion, der producerer investeringsgoder. Faldende profitrate betyder for enkeltkapitalen faldende investeringer, overproduktion $\mathrm{i}$ forbindelse med overakkumulation betyder for totalkapitalen, at merværdien ikke kan realiseres, dette igen betyder faldende profitmasse og dermed for totalkapitalen, at investeringer i udvidelse eller endog fastholdelse af produktionen hører op. Vanskelighederne ved at realisere merværdien fremstår som vanskeligheder ved på markedet at sælge varerne til gældende priser, som vanskeligheder ved at realisere gældende profitter på grund af utilstrækkelig efterspørgsel. Dermed fremgår, at med den større vægt sektor I har antaget uantastet i den lange fase i efterkrigstidsudviklingen, bliver efterspørgselsforholdene på hele markedet for produkter af kapital, og deres stabilitet af voksende betydning for hele den kapitalistiske produktionsmådes relative stabilitet, fordi de vedrører realiseringen af mer-

93. Dette er også den enkleste grund til at den organiske sammensætning må stige. Akkumulation er kapitalisering af merværdi, og når ekstensivering af produktionen finder sin grænse i reservearméens udtømning, kan kapitaliseringen af merværdi kun finde sted i form af konstant kapital - med andre ord kan, når mængden af levende arbejde er givet absolut, akkumulation kun betyde udvidelse af konstant kapital. Med bevarelsen af den eksisterende kapitalværdi (gennem overførsel til produkterne) vil tilskud af merværdi indebære en forhøjet kapitalsammensætning. Kort sagt akkumulation kan efter et vist punkt kun finde sted som udvidelse af den faste kapital.

94. I analysen i foregående afsnit. 
værdien, og dermed realiseringen af det samlede produkt fra hele sektor I's investeringsvareindustri.

Den absolutte overakkumulation, dvs. den tilstand hvor merværdien ikke kan udvides, fører til akkumulationens sammenbrud. Da denne proces imidlertid indenfor totalkapitalen finder sted mellem mange kapitaler er mulighederne til stede for en gradvis omstrukturering af kapitalen, som i højere grad tilpasser den samfundsmæssige merværdi til den samfundsmæssige kapital og som regulerer produktionen i forhold til den samfundsmæssige efterspørgsel, således som denne kommer til udtryk i markedsefterspørgslen. ${ }^{95}$ Denne proces, der er det samme som frembringelsen af

95. At den »glidende « udligning (udrensning) ikke har fundet sted, og ikke kan finde sted i et omfang, der sikrer en »krisefri« kapitalisme, skyldes netop akkumulationens cykliske bevagelsesform. Overophobning af kapital, videreeksistensen af et forældet kapitalapparat og fuld ekstensivering af produktionen i boom-fasen fører til at akkumulationen fortsætter ud over det logiske slutpunkt og at krisegennemslaget derfor får sin voldsomme og kumulative karakter (hele faldet i beskæftigelsen i industrien fandt sted i andet halvår 74 fra 310. - 275.000, Børsen 28.11. 77). I en OECD-rapport (Towards full employment and price stability, OECD juni 77) gør en gruppe udvalgte eksperter højkonjunkturens ledsagefænomener til den virkelige grund til krisen. Der ville, siger gruppen, være kommet et stærkt opsving i 72-73 under alle omstændigheder, men på grund af en række eksterne omstændigheder (som især kom til udtryk i USA's deficit på udenrigshandelen) blev der foretaget ekstraordinære ekspansive skridt, som førte med sig, at ekspansionen i udpræget grad tog form af monetar ekspansion. »Det var den ekstreme rate af monetær ekspansion, som var ansvarlig for de spekulative fænomener, som ledsagede boom'et. Priserne på fast ejendom, guld og andre traditionelle tilflugtssteder for nervøs kapital i inflationstider steg kraftigt. Hamstring og spekulation i lageropbygning af varer, men også opsamling af værdi udvikledes. Dette hyperaktiveredes af en serie af dårlige høstresultater i landbruget.«

Konklusionen på »What went wrong? « er hos OECD-gruppen - ikke overraskende - at krisen kan forståes indenfor traditionel $\emptyset$ konomisk analyse. »Vores tolkning af den seneste historie er, at det vigtigste fænomen var en usædvanlig ophobning af uheldige forstyrrelser, som sandsynligvis ikke gentages i samme skala, hvis indflydelse faldt sammen med nogle undgåelige fejl i den økonomiske politik.« Krise og spekulation, de følges ad. Men det mener vore $\mathrm{OECD}$-eksperter nu ikke, den $\phi$ konomiske sagkundskab har andre kort på hånden. Ganske vist $\mathrm{g} ø \mathrm{r}$ arven efter 71-75 det »vanskeligt at fastlægge politikken for de nærmeste år«, men » Vi vil dog afvise det synspunkt, at de eksisterende markedsorienterede $\varnothing$ konomiske systemer og demokratiske politiske institutioner har slået fejl. Hvad der behøves er en bedre udnyttelse af eksisterende instrumenter i den $\varnothing$ koonomiske politik og bedre funktionering og styring af markedsmekanismerne.« (p. 16-17).

Ovenstående skal derfor nærmere end at bortforklare krisens nødvendige gennemslagsform, pege på hvorfor dette gennemslag ikke »virker til bunds« men fra et vist punkt kan udvikle sig i et stagnativt forløb, hvor det så bliver vanskeligt at pege på hvilke renselseseffekter, der betinger et opsving. 
den gennemsnitlige profitrate (heraf fremgår hvorfor frembringelsen af den samfundsmæssige profitrate er så vigtig) finder sted på bekostning af enkeltkapitalerne og ved hjælp af intensivering af udbytningen. For enkeltkapitalerne betyder det på den ene side tvang til kapitalisering af produktionen, på den anden side for de enkeltkapitaler, hvis produktionsbetingelser har ligget under gennemsnittet, og som derfor med den gældende markedspris har realiseret mindre end den gennemsnitlige profitrate, at deres profitbetingelser med sænkning af markedsprisen/produktionsprisen forværres yderligere.

For de svageste enkeltkapitaler betyder krisen derfor en yderligere svækkelse, evt. med udrensning til følge. For de stærkere kapitaler, at udrensningen skaber »Lebensraum «, at markedet vokser for den enkelte kapital, selvom det er stagneret eller »skrumpet « for totalkapitalen, dermed bedre kapacitetsudnyttelse og forøget profitabilitet for de i forvejen profitstærke enkeltkapitaler.

Om denne proces i krisen, som antagelig er virksom, fører til fornyet prosperierende akkumulation kan ikke afgøres før processen er gennemløbet, før genopsvinget er i gang. Der gives ikke nogen absolut tilstrækkelig profitrate, som kan afgøre hvornår processen tager fart igen; dertil kommer, at processen tillige afhænger af enkeltkapitalernes forventninger til bæredygtigheden i opsvinget, til markedets vedvarende udvidelse. Sat på spidsen kan man sige, at opsvinget kommer ikke, før det er kommet, men det kommer i hvert fald ikke, før profitforholdene er forbedret væsentligt i forhold til den fase, hvor krisen udløstes.

Betingelserne herfor er:

1. destruktion for kapitalvaerdi som gør den resterende kapital mere profitabel fordi merværdien »bevares « og

2. forøgelse af udbytningsgraden.

Selvom disse processer må antages at forløbe i den nuværende fase, er mulighederne til stede for at kapitalismen kan fortsætte i en stagnativ fase.

Udviklingen efter den kraftige tilbagegang i slutningen af 74 og i 75 kunne tyde herpå. Mens produktionen faldt i 75 (til dels som følge af lagerreduktioner, der skønsmæssigt modsvarer fald i produktion på mere end $1 \%$,) var den i begyndelsen af 76 stigende, og nu nærmest stagneret. Der er derfor ikke tale om et egentligt sammenbrud i produktionen, eller en skrumpning af markedet absolut, men nok om en skrumpning i kapitalistisk forstand, i forhold til den ophobede produktionskapacitet i boom-årene og 
i forhold til den udvidelse af kapaciteten, som er en følge af den intensivering af arbejdsprocessen, som alene disciplineringen af arbejdskraften under krisen fører med sig, og af de produktivitetsforøgende investeringer som skærpelsen af konkurrencen påtvinger enkeltkapitalisterne. ${ }^{96}$

Selvom der primært er tale om rationaliseringsinvesteringer, kan man roligt antage, at der tillige er tale om en udvidelse af produktionskapaciteten hos enkeltkapitalerne, som søger at tage højde for dels den konkurrenceforbedring, som rationaliseringen havde sigte på, og som gerne skulle give sig udtryk i en relativ udvidelse af enkeltkapitalernes marked, og dels søger at tage højde for et kommende opsving eller en markedsudvikling, som ikke kan forudberegnes for enkeltkapitalen. For totalkapitalen er der tale om, at det stagnerede marked med den stagnerende akkumulation optræder som et relativt skrumpet marked, med konsekvens at produktionskapaciteten fastlåses eller indskrænkes. Processen blandt de mange kapitaler er derfor at akkumulation af c-fix hos nogle må modsvares af destruktion af c-fix hos andre, i værdimæssig og i stoflig henseende. ${ }^{97}$ Selvom investeringsomfanget og fornyelsen af den faste kapital ikke har samme omfang som i opsvings- eller boomfasen, er der kun for totalkapitalen som helhed, men ikke blandt enkeltkapitalerne tale om stagnation forstået som stilstand. Kampen for at vælte tabet over på andre fortsætter her som en kamp for at forbedre sine produktionsbetingelser relativt, om at sænke sine produktionsomkostninger overproportionalt.

At der er tale om stagnation bekræftes også af beskæftigelsestallene, som viser at industriens beskæftigelse siden dykket i slutningen af 74 er stagneret ${ }^{98}$ med en svagt faldende tendens, som angiver at rationaliseringseffekten, som ovenfor angivet, virker kraftigere end stigningen i produktionen.

96. Der findes endnu ikke opgørelser over investeringer foretaget under krisen, men en antydning af at investeringerne i det mindste er kommet i gang igen, findes i tallene for import af maskiner og udstyr. Både i 76 og i 77 er importen heraf steget (i faste priser ca. 10\% for de første $8 \mathrm{mdr}$ i 77 i forhold til samme periode 76, Børsen 17.10. 77).

97. Krisens differentierede gennemslag er derfor afgørende for virkningen af de politiske indgreb, der sættes ind i krisen. Eks. hvad betyder indkomstpolitik i betydningen generel lønfastlåsning i forhold til krisens evt. udrensning af »løntunge« virksomheder? For en vurdering af politikkens strukturelle funktionsbetingelser og effekter, er derfor en differentiering af krisegennemslaget mht. en række relevante forhold nødvendig (store/små kapitaler, løntunge/ kapitalintensive kapitaler, kapitaler med hastig eller langsom produktivitetsudvikling).

98. Med nogle udsving især i forbindelse med politiske forlig, se Børsen 29.11.77. 
Selvom der ikke er tale om et sammenbrud, så udviser stagnationsfasen derfor alligevel stort set alle de fænomener, der karakteriserer krisen, fordi selv stagnation i kapitalismen er en krisetilstand. Stagnation er for kapitalen en uting, som er i modsætning til dens formål, akkumulation af merværdi. At den (kapitalismen) kan videreeksistere i tilsyneladende usvækket form, skyldes at den i sine bestanddele som enkeltkapitaler netop »udvikler sig efter sit begreb «, ekspanderer mens andre dele går til grunde. Konsekvenserne er:

a. Konkurrencen skærpes,

b. Kapitaler udrenses (enten som udrensning, nedlæggelse af hele enkeltkapitaler, eller som rationalisering, divisionalisering etc.). Denne proces kan naturligvis kun ses i sammenhæng med gennemsættelsen af nye produktionsbetingelser på verdensmarkedet, hvad det tydeligst kommer til udtryk i rationaliseringen af tekstilindustrien i DK og det øvrige Vesteuropa (også værftsindustrien er eksempel herpå).

c. Centralisering. Selvom den danske kapitalstruktur er præget af mange små og mellemstore kapitaler uden nogen udprægede koncentrationstendenser, er der ikke noget til hinder for at udviklingen kan have været ledsaget af en modsvarende centralisering af kapitalen. Denne proces formidles i krisen, med dens karakteristiske vækst i efterspørgslen efter kredit pga. profitmangel, især af finanskapitalen i dens forskellige former (bankkapital, investeringsinstitutter, finansieringsinstitutter, etc.).

d. Økonomisering med den konstante kapital.

e. Forøgelse af udbytningen, gennem intensivering, afskaffelse af forskellige tilkæmpede goder, udhuling af sociale ordninger.

f. og først og sidst (indtil videre) reallønsænkning, og i flere tilfælde endog nominallønsænkning (eks. i byggefagene og indenfor jern- og metal).

\subsection{Den stagnative karakter}

Om årsagerne til at den aktuelle krise ikke har, eller måske ikke endnu har udviklet sig til en dybtgående renselseskrise med sammenbrud i cirkulationen og reproduktionen af kapital, kan endnu kun fremsættes formodninger. Blandt de væsentligste grunde kan peges på, at ikke hele den producerede merværdi er akkumuleret, men en stor og stigende del er anvendt til uproduktivt forbrug, især i statsligt regi. 
Med udbredelsen og udviklingen af de keynesianske reguleringsinstrumenter i efterkrigsperioden har det statslige forbrug fået en automatisk ${ }^{99}$ anticyklisk effekt, som til en vis grad sikrer, at »die Endnachfrage « ikke falder i takt med krisens udbredelse og væksten i arbejdsløsheden. Dette har taget et stigende omfang, ifølge finanslovforslag for 1978, er henved $30 \%$ af statens udgifter deficit-finansierede, uden, at der er tale om, at staten fører en bevidst keynesiansk krisemanagementspolitik, snarere tvartimod. Ses bort fra de »automatiske « virkninger, er statens andel af det samlede forbrug nærmest faldet. Siden 72 er statens investeringer gået tilbage, krisen er ledsaget af nedskæringer på social- og undervisningsbudgetter, af stramninger af finanspolitikken på indkomstsiden etc.

En anden vigtig grund kan være kreditforstrækningen til den private kapital. Både konsumentkreditten og cirkulationskreditten er tilsyneladende fortsat uberørte af udviklingen i den materielle produktion. Krisen i DK har ikke (som i BRD) i den første fase været karakteriseret af en krise i kreditkapitalen, bankkrak o.lign. Sandsynligvis har opretholdelsen af betalings- og kreditsystemet sikret, at tilbagestrømningen af betalingsmidler har forløbet gnidningsfrit og ikke bidraget til at fremkalde konkurser, krak.

Men for både statslig deficit-spending og for kreditforstrækning gælder, at de er »veksler« på fremtidigt produceret merværdi. Forudsætningen for at tilbagebetalingen ikke skal blive en yderligere belastning for en klemt profitrate, eller omvendt forudsætningen for at deficitspendingen fortsat kan være virksom er, at stagnationen afløses af vækst, at krisens renselse bliver virksom nok til at sikre genopsving, hvad fortsættelsen af den statslige købekraftsudpumpning netop tendentielt modvirker. Eller at tilbagebetalingen væltes over på arbejderklassen gennem en politik, der sikrer fastholdelse af lønnen og forøgelse af skattetrykket med udhuling af reallønnen til følge. (At det drejer sig om en alvorlig belastning fremgår af Vismændenes beregninger ifølge hvilken alene tilbagebetalingen af kortvarig kredit overfor udlandet i renter og afdrag vil belaste betalingsbalancen i 1980 med ca. 8 mia. eller næsten lige så meget som hele underskuddet i 1977, hertil kommer tilbagebetalingen af indenlandske statslån.)

Den væsentligste hæmsko for en egentlig keynesiansk kriseregulering synes dog at være, at den »magiske« virkning af det statslige forbrug,

99. Med automatisk menes selvudløsende, det betyder ikke, at denne effekt kan udjacvne cykliciteten, men at den virker modgående. 
acceleratoreffekten er sat delvist ud af funktion. Med ledig kapacitet, og uden udsigt til et selvbærende konjunkturopsving fører statslig induceret efterspørgsel i første række til højere kapacitetsudnyttelse, evt. sænkning af arbejdsløsheden, forøget import, men ikke til fornyede investeringer, dermed ikke til en udvidelse af akkumulationen og ikke til en selvforstærkende prosperitet. Produktionsfremgangen bliver nфjagtig så lang som underskudsfinansieringen af efterspørgselsforøgelsen varer. Det forventede opsving udebliver og med det mulighederne for fastholdelse af konsumforøgelsen.

Hertil kommer ikke mindst, at den økonomiske udvikling i DK er aldeles afhængig af niveauet på verdensmarkedet, og underskudsbudgettering i DK har kun ringe eller ingen effekt herpå. Vækst i DK afhænger derfor af vækst i de konjunkturbærende lande, nu som før ligger DK i en venteposition i forhold til et udefrakommende opsving, og betingelserne for at kunne deltage heri er, at »konkurrenceevnen « og profitforholdene for dansk industri er gunstige i forhold til konkurrerende kapitaler. ${ }^{100}$ Det skal jeg vende tilbage til i forbindelse med en vurdering af udviklingen i DK i forhold til udlandet.

Endelig kunne man forestille sig, at genopsvingets udeblivelse (stagnationen) skyldtes, at radikalisering og modstand $i$ arbejderklassen hindrer at krisens gennemslag ledsages af en forstærket udbytning. Det sidste er der dog ikke meget der tyder på, langt snarere er krisen præget af en aktiv accept af reallønsænkning fra den organiserede arbejderbevægelse (og i nogle tilfælde af nominallønsænkning, bla. anbefalet indenfor jern- og metal), og passiv godkendelse heraf fra den største del af arbejderklassen. Krisen synes mere at have betydet en styrkelse af reformismens positioner i arbejderklassen end en udbredelse af legitimitetsproblemerne. Trods massive indgreb mod arbejderklassens lønog levevilkår fra den socialdemokratiske regering, er opbakningen fra fagbevægelsen vokset og kommer hyppigere og stærkere til udtryk. Også indenfor fagbevægelsen synes de socialdemokratiske positioner styrket på bekostning af de radikal-reformistiske fremstød (a'la DKP). Det behøver dog ikke alene at være udtryk for en $\emptyset$ get

100. Det var problemstillingen i 50'erne, og det er problemstillingen nu. Vi har hørt i de seneste mange rapporter fra Vismændene, og vi vil høre det i de næste mange rapporter: Vi må vente på et konjunkturopsving i de toneangivende lande.

At nægte dette (som Madsen/Vangskjær) er efter min mening at fornægte realiteterne. 
opbakning, men kan tillige være udtryk for en samling og opstramning af de »socialdemokratiske kræfter « $\mathrm{i}$ et fors $\emptyset \mathrm{g}$ på at hindre, at en kritik bryder igennem og sætter spørgsmål ved legitimiteten af den førte politik.

\subsection{Udviklingen i forhold til andre nationale kapitaler}

Selvom disse overvejelser ikke giver grund til at afvise, at der for DK er tale om en overakkumulationskrise, kan en række forhold sætte spørgsmålstegn ved betimeligheden af denne opfattelse som indgangsled til forståelse af det nuværende krisegennemslag i DK.

Det kan synes naivt at diskutere overakkumulation her, som et internt nationalt krisegrundlag. I betragtning af at den danske industri, som ovenfor er karakteriseret ved at være »afhængig « i flere henseender, i kraft af det begrænsede nationale marked i forhold til enkeltkapitalernes produktionsbetingelser, i kraft af sammenfletningen på verdensmarkedet via høje import/eksportkvoter, i kraft af, at import/eksport i stor udstrækning består af råvarer og halvfabrikata (for import ca. 70\%), i kraft af institutionelle forhold og valutariske bindinger, kan der ikke være tale om selvstændig overakkumulation i DK, men kun i forbindelse med overakkumulation på verdensmarkedet absolut taget. Set fra denne side er det klart, at overakkumulation i et land som DK, kun kan forståes, som en afspejling af de samme tendenser på verdensmarkedet. Det betyder derimod ikke, at krisen i DK (hvis tesen er rigtig) kun kan forståes som påtvunget udefra eller som relativ i forhold til andre nationale kapitaler. Det sidste synes at være krisemodellen både hos DØR og hos SØ. Danmark er i krise af en række indenlandske årsager (løn- eller omkostningsstigninger) som kun er relative kriseårsager, kun fremkalder krisen fordi udviklingen her har været »svagere « eller »skævere« end i de øvrige kapitalistiske nationer. Snarere betyder sammenfletningen, at den danske industri kun kan forståes som »pars totalis«, som afhængig, men ikke som underordnet, og ikke nфdvendigvis som forskellig fra andre nationalkapitaler. Kriseudviklingen her behøver derfor ikke at skulle henføres til særlige karakteristika ved den danske industri (arbejdsintensiv, nicheproduktion el. lign.) det så meget mindre, som den stort set har udviklet sig parallelt til udviklingen i andre lande.

»Indenlandske årsager « til krisen betyder derfor heller ikke her udelukkende de nationale særtræk, som skaber en relativ krise i forhold til udlandet, men krisetendenser som også den danske industrikapital udvikler i 
kraft af, at den er kapital og dernæst i kraft af, at den er en afhængig kapital. På den anden side er det klart, at udviklingen i DK og udlandet, selvom de mht. de sammenfattede resultater udvikler sig stort set synkront, i de underliggende forhold, dvs. i akkumulationsformerne, udvikler sig forskelligt pga. historiske nationale særtræk (forskellige forudsætninger både mht. produktionens udgangspunkt og mht. politiske forhold), og at den forskellige udvikling afsætter forskellige betingelser for krisegennemslaget og for at deltage $\mathrm{i}$ et kommende opsving. Derfor må nationale særtræk naturligvis indgå med stor vægt i analysen.

Ved vurderingen af hvilken vægt, der skal tillægges nationale hhv. internationale forhold, og i vurderingen af hvilke de nationale forhold er, som, om ikke har fremkaldt krisen, så dog sætter nødvendigheden af bestemte renselsesforl $\varnothing \mathrm{b}$ heri for at sikre den danske industri muligheden for at »løbe med $\mathrm{i}$ « opsvingsfasen, ved denne vurdering træder problemerne ved at basere undersøgelsen på og forsøge at trække konsekvenser af den form for empiri, der er anvendt her, frem. Karakteristisk for det statistiske materiale er for det første, at det er struktureret ud fra den fremherskende national $\varnothing$ konomiske opfattelse af de $\varnothing$ konomiske funktionssammenhænge, og at den reflekterer de $\varnothing$ jeblikkelige (som tendens) informationsbehov som styringsmulighederne og -problemerne fremkalder og derfor ikke kan sige noget om de relationer, som skal ligge til grund for konklusionerne her, men højst under en række forudsætninger angive bevægelsesretningen i værdistørrelserne som relative forhold. For det andet, og det er vigtigt $\mathrm{i}$ denne sammenhæng, at der er tale om ex post-registreringer, som kun angiver det sammenfattede resultat, men ikke de udviklingstræk, der fremstår i dette. Det samme blev nævnt tidligere i forbindelse med problemerne ved empirisk at indikere de modgående faktorers ophævelse af den tendentielle udvikling i kapitalsammensætningen mht. dennes gennemslag i profitratens fald. Det forhold gør sig på ny gældende her, og jeg skal prøve at klargøre hvordan.

Underforstået i fremstillingen af krisen som en overakkumulationskrise ligger, at den danske industrikapital ikke udvikler sig undergennemsnitligt mht. produktivitetsudviklingen, at den så at sige, som tidligere nævnt, udvikler sig som en ligeværdig del af verdensmarkedskapitalen (indenfor nationale grænser), at overakkumulationen er real som overakkumulation, dvs. at krisen har årsag i, at yderligere kapitaludlæg under givne udbytningsbetingelser ikke tilføjer yderligere merværdi. Var problemet omvendt, at den 
danske industri havde akkumuleret undergennemsnitligt, at den tilhørte den lavorganiske kategori, som i opsvings- og højkonjunkturer er markedsprisbærende, men som i skærpede konkurrencesituationer udrenses eller realiserer undergennemsnitlig profit, da ville krisegennemslagets fænomenologi have været stort set den samme: ${ }^{101}$ ophobning i højkonjunkturen af produktiv kapital, som værdi og i stoflig henseende, realiseringsvanskeligheder, men nu pga. undergennemsnitlige produktionsbetingelser, hvad der ikke fremstår i de statistiske mål, akut fald i profitrate og masse, krak etc.

Set fra det »sammenfattede resultat « kan det således være vanskeligt at angive krisens baggrund. Jeg skal derfor nedenfor søge at underbygge tesen om dansk industris gennemsnitlighed, hvad angår produktivkraftsudvikling, gennem en række sammenlignende indikationer.

Tabel 10. Omkostudviklingen i \% fra 1973 til 1976

\begin{tabular}{lccccc}
\hline & $\begin{array}{c}\text { Prod./ } \\
\text { time }\end{array}$ & $\begin{array}{c}\text { Lønomk./ } \\
\text { time }\end{array}$ & $\begin{array}{c}\text { Lønomk./ } \\
\text { prod.enh. }\end{array}$ & $\begin{array}{c}\text { Samme i } \\
\text { dollar }\end{array}$ & Rangord. \\
\hline USA & 2,5 & 31,4 & 28,2 & 28,2 & 4 \\
Canada & 4,1 & 45,9 & 40,1 & 42,2 & 9 \\
Japan & 11,3 & 64,4 & 47,7 & 35,0 & 7 \\
Belgien & 13,1 & 50,9 & 33,3 & 41,1 & 8 \\
Danmark & 22,9 & 60,7 & 30,7 & 30,1 & 5 \\
Frankrig & 15,3 & 59,0 & 37,8 & 28,1 & 3 \\
BRD & 19,4 & 36,0 & 14,0 & 20,0 & 1 \\
Italien & 9,3 & 92,7 & 76,4 & 23,6 & 2 \\
Holland & 11,3 & 49,3 & 31,1 & 45,0 & 10 \\
Sverige & 3,9 & 73,3 & 66,8 & 66,6 & 12 \\
Schweitz & 6,8 & 23,4 & 15,6 & 47,0 & 11 \\
England & 0,9 & 84,4 & 82,9 & 34,8 & 6 \\
\hline Gennemsn. & 9,5 & 56,0 & 42,1 & 36,8 & - \\
\hline
\end{tabular}

Kilde: Det amerikanske arbejdsministerium, juli 77, cit. efter Udenrigsministeriets Tidsskrift for Udenrigsøkonomi, okt. 77.

101. Det gælder for krisens begyndelse, renselsesforløbet gennem hele krisen ville naturligvis have været et andet, men dels er det endnu ikke muligt at konstatere dette, dels ville det kræve dyberegående sammenligninger med andre nationale kapitaler. 
Sammenligner vi først udviklingen i produktiviteten i DK med en række $\varnothing$ vrige kapitalistiske lande, viser den i forlængelse af, hvad der tidligere er fremført fra anden side at produktiviteten i DK også i krisens første år er steget kraftigere end i udlandet, se tabel 10.

En evt. undergennemsnitlig udvikling kommer heller ikke til syne i udviklingen af markedsandelen for DK- industri i 70'erne (i modsætning til 60 'erne, hvor markedsandelen faldt med ca. 1/2\% årligt (gennemsnit frem til 72 og mere fra 72-73)). Tværtimod er markedsandelen fra 72/73 - 76 bevaret $(0,8 \%)$, hvor det er værd at lægge mærke til at DK klarede sig bedre end en lang række sammenlignelige lande (bla. Sverige) og på linie med USA og Japan. Set fra denne side tyder empiriske indikatorer derfor på, at gennemsnitligheden har gjort sig gældende både mht. produktivitetsudvikling og profitkvoteudvikling, langt mere end undergennemsnitligheden. Men, som det blev fremført ovenfor for enkeltkapitaler, så gælder det også for nationalkapitaler, når disse betragtes som gennemsnit, ${ }^{102}$ at de, der producerer under de bedste betingelser, de som realiserer en ekstraprofit i forhold til den gennemsnitlige profitrate, at de også i krisen trods samlet stagnation gennemløber en relativ vækst i forhold til nationalkapitaler, som producerer under mindre gunstige betingelser. Derfor er en placering som gennemsnitlig for en kapital (her nationalkapital) heller ikke tilstrækkelig i konkurrencen med kapitaler med bedre produktionsbetingelser, tværtimod er det at være gennemsnitlig det samme som at være utilstrækkelig i forhold til overgennemsnitlige. Det sammenligningsgrundlag, som kommer til udtryk i bl.a. DØR's rapporter og som er baggrunden for bekymringerne om »den danske konkurrenceevne « har derfor sin realitetsstatus deri, at DK som nationalkapital må udvikle sine profitbetingelser i overensstemmelse med et gennemsnit, som betinges af de højest udviklede kapitalistiske lande. At pukke på, at DK udvikler sig »lige så godt som de fleste« kapitalistisk set, (som implicit ligger hos $\mathrm{S} \varnothing$ og direkte hos Birger Linde) er derfor at se bort fra den kapitalistiske logik, som eksekveres i konkurrencen, og som dikterer enkeltkapitalerne ikke alene at producere med gennemsnitsprofit, men at i forhold hertil realisere en ekstraprofit. Dette imperativ, der for enkeltkapitaler i højkonjunkturer er en betingelse for at bevare markeds- og

102. Nationalkapital betyder her således kun gennemsnit af enkeltkapitaler, og anvendes ikke som en særskilt kapitalkategori. Alligevel må dog fastholdes, at en lang række nationale forskelle, politiske forhold, lokaliseringsforhold etc. skiller nationale kapitaler, og »samler til nationalkapitaler«. 
profitandele, bliver i krisen betingelsen for overhovedet at overleve. Når profitraten falder til nul eller bliver negativ (sml. tabel 8) og forbliver lav gennem længere tid, betyder hvert omslag forbrug af deres akkumulerede kapitalværdi, dermed er deres eksistens som kapital i realiteten allerede ophørt, kun et fornyet opsving kan redde dem. Tilsvarende gælder naturligvis for nationalkapitaler, som bestående af verdensmarkedskonkurrerende enkeltkapitaler, som værende et statistisk gennemsnit herfor.

Dette kommer kun fordrejet til udtryk i markedsandelen (som er forholdet mellem markedets vækst og eksporten for et land). Udviklingsforskellene mellem BRD og USA er illustrerende herfor. Mens USA har bidraget til forøgelse af verdensmarkedshandelen gennem faldende hjemmemarkedsforsyning (stigende importforbrug) og altså nok har holdt sin andel af verdensmarkedshandelen, men har mistet større andel af hjemmemarkedshandelen, har BRD ligeledes holdt sin markedsandel på verdenshandelen, men har tillige forøget sin hjemmemarkedsandel. Selvom konkurrenceevne får samme udtryk i markedsandele, har udviklingen altså været vidt forskellig.

For DK gælder i sammenligning hermed, at importmængden er vokset mindre end mængden i eksporten, og at svarende hertil, at DK's eksportandel af verdenshandelen er vokset mere end importandelen, heller ikke fra denne side er der derfor tale om undergennemsnitlighed.

Men denne konstatering af gennemsnitlighed mht. produktivitetsudvikling for DK i 70'erne er ikke overraskende. Jeg har tidligere været inde på, at det netop er det mest karakteristiske træk ved den danske industris udvikling, at efter 67/68 har produktivitetsstigningerne været store og uden modsvarende stigninger i kapitalintensiteten. Denne tendens var væsentligt forskellig fra tendensen i 60'erne, og altså, som det kommer til udtryk i hvert fald mht. produktivitetsudviklingen, også forskellig fra udviklingen i en lang række andre kapitalistiske lande.

Er denne udvikling ikke betinget af ændringer i kapitalindsatsen, finder den, som omvenfor antydet, sine grænser primært i arbejderklassens villighed til at acceptere forøget intensivering, men denne har siden begyndelsen af 70'erne ikke i større udstrækning udadtil fremstået som en afgørende skranke for produktivitetsforøgelse ad denne vej. Med baggrund heri, og med baggrund i de seneste års erfaringer med indkomstpolitikkens gennemførelse, synes accepten af den socialdemokratisk orienterede fagbevagelse og dens hegemoni $i$ arbejderklassen at vare et af de mest afgфrende »strukturtrak«ved den danske kapitalisme. 
Mulighedsbetingelserne for reformismens succes var dog blandt andet udviklingen i kapitalapparatet. Uden modsvarende ændringer heri, havde, reformistisk hegemoni eller ej, intensiveringen og produktivitetsforøgelsen ikke kunnet strækkes år for år i næsten tiår. (Siden 67 har produktivitetsstigningen faktisk varet storre $i \mathrm{DK}$ end $i$ alle andre sammenlignelige lan$d e$, sml. B. Linde og tabel 10). Havde den danske akkumulationsudvikling væsentligere og alene været bundet til arbejdsintensivering mere end dette var gældende i udlandet, ville betingelserne for krisegennemslaget tilsvarende have været forskellige: med en antagelig grænse for intensiveringsforøgelser i krisen ville den danske industris kriserenselse være betinget af fornyet kapitalisering af produktionsprocessen i et relativt større omfang, og i forlængelse heraf være bundet til kapitalisering af profit, der på grund af den lave kapitalsammensætning måtte være undergennemsnitlig eller kun gennemsnitlig (pga. arbejdsproduktivitetsforøgelsen). Dette viser således hen til vigtigheden af sammenligningen af udviklingen i kapitalforholdet med de $\varnothing$ vrige kapitalistiske lande.

Selvom DK traditionelt går for at have en lav investeringskvote, opvejes dette med hensyn til kudskiftningen af de »aktive « kapitalelementer af, at en stor del af investeringerne (51,3\% af de faste bruttoinvest. i 68-72), mere end i noget andet OECD-land, har været investeringer i maskiner og udstyr. Også investeringskvoten for maskiner og udstyr er for DK blandt de højeste. ${ }^{102 a}$ Så selvom stigningen i kapitalintensiteten i 60'erne var større end i 70'erne, må en del af den store produktivitetsstigning siges at have haft sin betingelse i den relativt hastige udvikling i kapitalforholdet, også sammenlignet med andre lande. ${ }^{103}$

Heller ikke når man betragter udviklingen $\mathrm{i}$ kapitalinvesteringerne synes der således at være nogen baggrund for at antage, at industrien her hjemme er blevet relativt »lavere organisk «, snarere tværtimod. Dermed er dog ikke sagt, at industrien hører til blandt de højest udviklede mht. kapitalsammensætning, etc., blandt dens væsentligste fortrin, hvis den har nogle, i forhold til en række nationale kapitaler, synes stadig at være rådigheden over en veluddannet, og frem for alt veldisciplineret og intensiveringsduelig arbejdskraft og en fagbevægelse og et arbejdsmarkedsreguleringssystem, der sikrer kon-

102a 12,1\% af BNP, se OECD 1975.

103. Sammenlignes væksten i invest. fra krisen i $67 / 68$ til toppunktet i boom-fasen for BRD og DK viser det sig at forløbet har været næsten ensartet, og at væksten fra bund til top har været lige stor (ca. 70\%). Kilde: Semmler/Hoffmann. op. cit. 
tinuitet i udbytningen. Bevarelsen og udbygningen heraf er tilsyneladende også blandt de væsentligste motiver bag politikken fra hhv. DA og LO - SD.

Sammenfattende mener jeg derfor, at de faktorer, der kan indikere den relative udvikling i den danske kapital kun understøtter tesen i forrige afsnit om, at den virkelige baggrund for den nuværende krise er overakkumulation af produktiv kapital i stoflig form og i pengeform.

Er baggrunden for udviklingen af statslige kriseinterventioner antagelser om, at krisen har sin baggrund i relative forhold for DK, må mulighedsbetingelserne for disse politikkers krisemodgående effekter eller, hvorvidt de initierende for opsvinget derfor ikke alene diskuterer i forhold til deres »konkurrenceforbedrende « virkninger, således som det ofte sker også på venstrefløjen (eks. i afvisningen af indkomstpolitik med den begrundelse, at andre lande også fører indkomstpolitik og af DK derfor kun i bedste fald undgår at forringe sin position), men må tillige diskuteres i forhold til modsætningsfyldte virkningsgrundlag, som overakkumulationens fremtrædelsesformer stiller overfor politikken. Dette skal være emnet for det afsluttende afsnit.

\section{Slutning}

Med den karakter af krisen, som jeg har søgt at fremstille i de foregående kapitler, er mulighederne for statslige indgreb, der sigter på at fremme et fornyet akkumulationsopsving, stærkt begrænsede.

Overvindelsen af den depressive stagnationsfase, som har afløst den bratte nedgang i slutningen af 74 og begyndelsen af 75 , forudsætter en forbedring af profitbetingelserne for enkeltkapitalerne. Selvom dette sandsynligvis allerede har fundet sted i betydeligt omfang, indicerer den forsatte stagnation for det første, at forbedringen ikke har været tilstrækkelig, men for det andet, og det er et væsentligt karakteristikum, at en isoleret profitforbedring i DK ikke er tilstrækkelig til at sikre et genopsving pga. den danske industris afhængighed af konjunkturniveauet på verdensmarkedet. Ventesituationen er således fortsat en realitet, og som tidligere fremført (i foregående afsnit) sikrer den danske kapitals gennemsnitlighed alene ikke betingelserne for at deltage $i$ et genopsving med samme styrke som konkurrerende kapitaler. Dette hænger sammen med, at den danske industri fortrinsvis består af små og mellemstore kapitaler, som med verdensmarkedsgennemsnitlig profitrate kun akkumulerer utilstrækkeligt i forhold til 
større kapitaler. For DK som nationalkapital gælder derfor, at dens profitbetingelser skal være mindst gennemsnitlige, hvis den skal deltage i et opsving fra dettes begyndelse. Bliver profitforholdene kun forbedret utilstrækkeligt i forhold hertil, vil industrien, som det har været tilfældet tidligere, »halte efter « og først kunne ekspandere mht. markedsandele når opsvinget er i gang, dvs. først efter at have tabt andele.

Både med hensyn til at overvinde stagnationstilstanden nationalt, som med hensyn til at deltage $i$ et internationalt konjunkturopsving $\mathrm{i}$ en tidlig fase, er en forøgelse af profitraten, hhv. massen således en uomgængelig forudsætning. Mere af det samfundsmæssige arbejde må tilfalde kapitalen, mindre arbejderne, eller der må med Vismændenes ord, ske »en omfordeling til fordel for profitterne. ${ }^{104}$

Men med den nuværende krises karakter af overakkumulations og overproduktionskrise, som kommer til udtryk i stagnationen, er betingelserne for denne omfordeling langt fra modsætningsfri. Jeg skal forsøge at antyde dette.

Den profit, som kapitalen tilegner sig til et tidspunkt t, kan udtrykkes som $\mathrm{P}(\mathrm{t})=\mathrm{Y}(\mathrm{t})-\mathrm{W}(\mathrm{t}) \mathrm{L}(\mathrm{t})^{105}$

Profitten er således bestemt som den samfundsmæssige nyværdis (Y) overskud over lønsummen (WL). Forøgelsen af profittens andel kan finde sted, enten gennem forøgelse af Y, uden modsvarende forøgelse af lønsummen, dvs. gennem forøgelse af arbejdsproduktiviteten, eller gennem sænkning af lønsummen. ${ }^{106}$

Men som det er fremgået, indebærer overophobningen af produktiv kapital i stoflig form, at akkumuleringen af profit ikke finder sted som en udbygning af produktionskapaciteten. Når heller ikke reallønnen kan forøges, indebærer dette en stagnation i Y.

Forøgelsen af profitmassen har tidligere kunnet finde sted gennem en produktivitetsstigning, der var større end væksten i reallønnen, ${ }^{107}$ men hvor Y har været voksende.

104. Dansk Økonomi, november 76, p. 79.

105. Efter Hoffmann og Semmler: Kapitalreproduktion og indkomstpolitik, p. $46 i$ Kurasje nr. 14.

106. Jeg ser her bort fra effekter af prisstigninger. Kun såfremt prisstigninger influerer på $Y$, men ikke modsvares af lønstigninger, medfører de en forbedring af profittens andel. Men dette svarer til en lønsænkning i realtermer, hvorfor den bliver behandlet med det andet alternativ.

107. Se hertil Bredsdorff m.fl. op. cit. p. 36. 
Med stagneret $\mathrm{Y}$ indebærer produktivitetsstigninger et modsvarende fald i beskæftigelsen, eller at det betalte arbejde falder, både med hensyn til dets andel af Y, men også absolut.

Hertil kommer: Hvor den profitforbedrende effekt af løntilbageholdenhed, løndæmpning etc. tidligere hang sammen med at $Y$ voksede mere end lønnen, så betyder stagnation i Y, at profitforbedring forudsætter at reall $\phi n$ nen sankes.

Overakkumulation og stagnation indebærer således en uddybning af kapitalismens modsætninger på to planer:

1. Økonomisk: Produktivitetsudviklingen medfører nok en forøgelse af merværdiraten, men på bekostning af en modsvarende absolut nedgang $\mathrm{i}$ anvendelsen af levende arbejde, således at merværdimassen forbliver den samme. Mere af det samfundsmæssige arbejde tilfalder således kapitalen, mindre arbejderne, men mindre samfundsmæssigt arbejde overhovedet anvendes. Det, der er en immanent tendens i produktivkraftsudviklingen: afkortning af den nødvendige arbejdstid og »nedgang i den mængde arbejdskraft (det antal arbejdere), der overhovedet anvendes for at sætte en given kapital i bevægelse «, ${ }^{108}$ ophører med overakkumulationen, dvs. når kapitalen ikke udvides, med at være en tendens, bliver absolut. Selvom merværdiraten forøges, vokser den organiske sammensætning modsvarende med resultat at profitraten i heldigste fald (for kapitalen) forbliver konstant. 2. Politisk: Den eneste mulighed i den nuværende fase for at forøge merværdimassen (og raten samtidigt) består således i at sænke reallønnen absolut. Men for begge metoders vedkommende indebærer de en forværring af arbejderklassens levevilkår absolut, i det ene tilfælde ved at arbejdsløsheden forøges, i det andet ved at reallønnen for de beskæftigede sænkes. På dette punkt fremtræder det kapitalistiske samfund som et polært klassesamfund. Kapitalen kan kun videreeksistere og forbedre sin situation, direkte på bekostning af arbejderklassen. Dermed åbnes muligheden for at den $\varnothing$ konomiske krise bliver en politisk krise, og dermed for en radikalisering af arbejderklassen.

Men denne proces (forringelsen af arbejderklassens levebetingelser) er ikke i sin vorden, men har stået på siden midten af 75 (hvor krisen slog igennem mht. at bringe lønglidningen til ophør), altså i godt og vel to år uden at have

108. K. Marx, Kapitalen 3:2, p. 325. 
sat sig spor i radikalisering af arbejderklassen. Tværtimod har den sat sig spor i form af en opbakning af den reformistiske arbejderbevægelse.

Betingelserne for at det gnidningsløst har været muligt, at lade løsningen af krisen ske på arbejderklassens bekostning, og dermed betingelserne for at det forsat kan lade sig gøre, og for at den aktuelle form for indkomstpolitik, som mere og mere optræder som en fast forudsætning, kan videreføres efter 1979, eller omvendt grænserne herfor, lader sig ikke angive eksakt, men til forudsætningerne har sikkert hørt:

1. Den styrkelse af den reformistiske arbejderbevægelse, som presset fra højre har ført med sig. Reformismen er mere end før blevet garanten mod demonteringen af velfærdsstaten.

2. Trykket fra en reservearmé på 200.000 .

3. Sammensætningen af denne reservearmé. Den består fortrinsvist af grupper med marginal tilknytning til arbejdsmarkedet (for $2 / 3$ 's vedkommende unge og kvinder og dertil en stor del ældre), af individualiserede grupper, med tilsvarende få muligheder for organiseret modstand.

4. At krisen foreløbig er slået igennem primært som en frembringelse af denne reservearmé, men ikke har været ledsaget af omfattende reduktioner i reallønnen for den del af arbejderklassen, der er beskæftiget $\mathrm{i}$ industrien (men derimod nok for ansatte i den offentlige sektor).

Men som det er fremgået ovenfor bliver profitforbedring stadig mere uden alternativ bundet til sænkning af reallønnen. Når dette ikke fremmer beskæftigelsen, men tværtimod, fordi det begrænser massernes konsum, forøger arbejdsløsheden; når ekspansionen på verdensmarkedet lader vente på sig, bliver det mere og mere velbegrundet at stille spørgsmålene:

Hvor længe vil den hidtil førte politik blive opfattet som legitim? og dermed:

Hvor længe og under hvilke betingelser kan reformismen undgå, at den $\emptyset$ konomiske krise bliver en politisk krise? 